\title{
On some new or poorly-known millipedes from Chile and Argentina (Diplopoda)
}

\author{
О некоторых новых и плохоизученных Авупарноногих \\ многоножках из Чими и Аргентины (Diplopoda)
}

\author{
S.I. Golovatch \\ С.И. Головач
}

Institute for Problems of Ecology and Evolution, Russian Academy of Sciences, Leninsky prospekt 33, Moscow 119071 Russia. E-mail: sgolovatch@yandex.ru

Институт проблем экологии и эволюции РАН, Ленинский проспект, 33, Москва 119071 Россия.

KEY WORDS: Diplopoda, taxonomy, new records, new species, Chile, Argentina.

КЛЮЧЕВЫЕ СЛОВА: Diplopoda, таксономия, новые находки, новые виды, Чили, Аргентина.

ABSTRACT. A fresh collection of Diplopoda from Chile and Argentina appears to contain 16 identifiable species, mostly richly illustrated, among which four are new: Argentocricus iguazu sp.n. (Rhinocricidae, Spirobolida) from Argentina, as well as Semnosoma eskovi sp.n., Abatodesmus simplicior sp.n. and Anaulacodesmus bifidus sp.n. (all Dalodesmidae, Polydesmida) from Chile. The following new synonymy is established: Monenchodesmus inermis Silvestri, 1903 = Monenchodesmus inermis nahuelhuapiensis Schubart, $1954=$ Monenchodesmus tiganus Chamberlin, 1957, syn.n. (the valid name the first). The species Anaulacodesmus lacustris Schubart, 1954, previously known only from the Andean parts of Argentina bordering on Chile, is recorded from Chile for the first time.

РЕЗЮМЕ. Свежая коллекция диплопод из Чили и Аргентины содержит 16 определимых видов, большинство из которых снабжены обильными иллюстрациями, включая четыре новых вида: Argentocricus iguazu sp.n. (Rhinocricidae, Spirobolida) из Аргентины, а также Semnosoma eskovi sp.n., Abatodesmus simplicior sp.n. и Anaulacodesmus bifidus sp.n. (все Dalodesmidae, Polydesmida) из Чили. Установлена следующая новая синонимия: Monenchodesmus inermis Silvestri, 1903 = Monenchodesmus inermis nahuelhuapiensis Schubart, 1954 = Monenchodesmus tiganus Chamberlin, 1957, syn.n. (валидное название первое). Вид Anaulacodesmus lacustris Schubart, 1954, ранее известный лишь из приграничных с Чили аргентинских районов Андов, впервые отмечен и из Чили.

\section{Introduction}

The millipedes of southern South America, of Argentina and Chile in particular, can most generously be termed as being still poorly known. The fauna of Argentina and adjacent areas of Bolivia, Paraguay, Uruguay and southern Brazil was reviewed not too long ago [Mauriès, 1998], but the latest synopses of Chilean Diplopoda are old and hopelessly outdated [Silvestri, 1905a; Chamberlin, 1957].

Biogeographically, the region is highly peculiar, long considered as part of the Austral realm. Thus, only one Chilean genus and species of the rather large Southern Hemisphere family Iulomorphidae (Spirostreptida) occurs in South America, the remaining nearly 80 species being known solely in southern Africa, Australia (together with Tasmania) and New Zealand [Korsós \& Read, 2012]. The large Austral family Dalodesmidae (Polydesmida) containing about 50 genera and $200+$ species is about equally diverse in southern Africa (together with Madagascar), Australia (together with Tasmania and New Caledonia), New Zealand and southern South America [Hoffman, 1980]. Most of the dalodesmids in South America appear to be confined to Chile and the immediately adjacent Andean parts of Argentina, with only one monotypic genus each encountered along the Atlantic coasts of Mar del Plata, Argentina and Santa Catarina, southeastern Brazil [Hoffman, 1979]. The small family Siphonotidae (Polyzoniida) also seems to represent an Austral element in the millipede fauna of South America, but its few species reach as far north as the Mata Atlantica forest habitats in Santa Catarina and São Paulo states, southeastern Brazil [Hoffman, 1971, 1979, 1980]. The small family Eudigonidae (Chordeumatida) (5-6 species in 3 genera) is endemic to the Andes of central Chile and Argentina [Demange, 1963; Shear, 1988], but the superfamily Heterochordeumatoidea it belongs to is basically Australasian, reaching New Zealand in the east [Shear, 2011].

All of the above four families can be seen as ancient Gondwanaic relicts, although these primitive Austral elements are now much reduced and overlain by later and evidently more successful faunal layers of Neotropical origins [Hoffman, 1979]. This pattern agrees quite well with common wisdom, including plant distributions and 
fossil evidence [e.g. Weston \& Hill, 2013]. The Neotropical components among Diplopoda are mostly represented by such highly species-rich families as Chelodesmidae, Paradoxosomatidae (both Polydesmida), Spirostreptidae (Spirostreptida) and Rhinocricidae (Spirobolida) which only barely reach Chile [e.g. Demange \& Silva, 1971a], but dominate the fauna of Argentina in the south [Hoffman, 1980]. Being the newest introductions, several anthropochore species, mostly of European origins, are rather common in South America as well, the southernmost record in the New World belonging to a species of the Euro-Mediterranean genus Cylindroiulus Verhoeff, 1894 (Julidae, Julida) in southern Patagonia, Chile [Shelley et al., 2014]. The distributions of Julida millipedes in South America, of course all introduced, have also been summarized by Shelley et al. [2014], but these authors have inadvertently omitted Blaniulus guttulatus (Bosc, 1792) (Blaniulidae, Julida) reported from Valparaiso and its environs [Silva \& Vivar, 1976].

The present paper is devoted to the taxonomic assessment of a fresh collection of Diplopoda made by several Russian zoologists in Argentina and Chile.

\section{Material and methods}

Most of the material treated below is housed in the Zoological Museum of the State University of Moscow (ZMUM + entry number), Russia, with some duplicates donated to the collection of the Museo Nacional de Historia Natural, Santiago, Chile (MNHN). Digital images of the specimens were taken in the laboratory and assembled using the Zerene Stacker software.

\section{Taxonomic part}

\section{Order Julida}

Family Julidae

Cylindroiulus britannicus (Verhoeff, 1891)

MATERIAL. Numerous $0^{7} \sigma^{7}$, 우 \& juv. (ZMUM 22358 ), Argentina, Villa la Angostura, National Park Arrayanes, $40^{\circ} 50$ 'S, $71^{\circ} 37^{\prime} \mathrm{W}$, ca $800 \mathrm{~m}$ a.s.1., Luma \& Nothofagus forest, under logs \& stones, 23.12.2013; numerous $\sigma^{7} \sigma^{7}$, 우 \& juv. (ZMUM $\rho 2359$ ), Villa la Angostura, National Park Nahuel Huapi, $40^{\circ} 44^{\prime} \mathrm{S}, 71^{\circ} 39^{\prime} \mathrm{W}$,

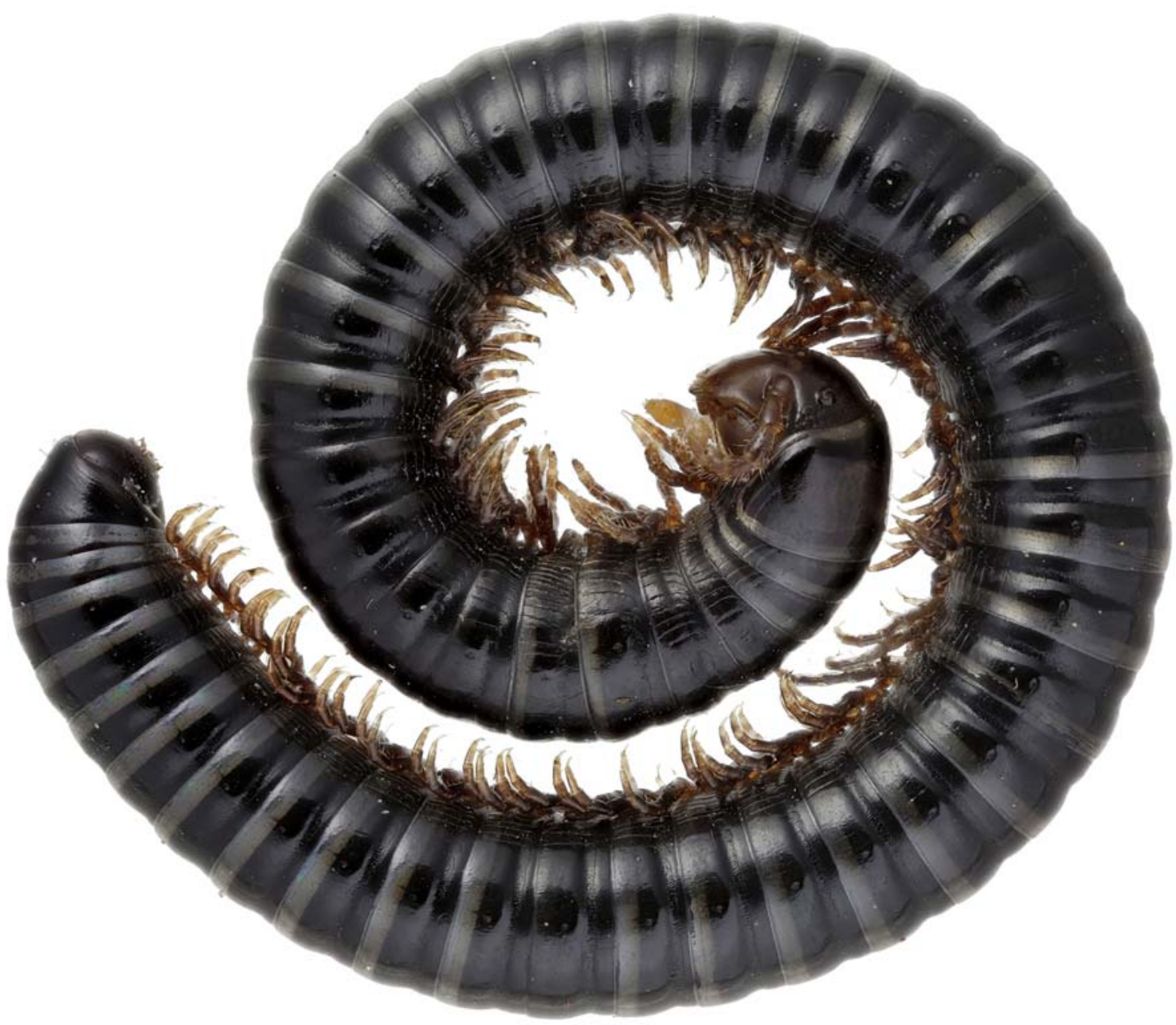

Fig. 1. Habitus of Zinagon chilensis (Silvestri, 1903), o from National Park Puyehue, lateral view. Picture by K. Makarov, not taken to scale. Рис. 1. Внешний вид Zinagon chilensis (Silvestri, 1903), О’ из национального парка Рuyеhuе, сбоку. Фотография К. Макарова, без масштаба. 
ca $900 \mathrm{~m}$ a.s.1., Nothofagus forest, under logs \& stones, 25.12.2013; numerous $\sigma^{\top} \sigma^{\top},++$ \& juv. (ZMUM 22360$)$, Villa la Angostura, $40^{\circ} 47^{\prime} \mathrm{S}, 71^{\circ} 40^{\prime} \mathrm{W}$, wet Carex meadow, litter, 29.12.2013; $2 \mathrm{O}^{\top} \mathrm{\sigma}^{\top}$, 5 우, 2 juv. (ZMUM 22363 ), Chile, National Park Alerce Andino, Sargazo Sector, $41^{\circ} 30^{\prime} \mathrm{S}, 7^{\circ} 37^{\prime} \mathrm{W}$, ca $350 \mathrm{~m}$ a.s.l., Nothofagus \& Podocarpus forest, 5-11.01.2014; 1 ○ (ZMUM p2370), Chiloe Island, Senda Darwin Biological Station (ca $15 \mathrm{~km}$ E of Ancud), $41^{\circ} 53^{\prime} \mathrm{S}, 73^{\circ} 40^{\prime} \mathrm{W}, 25 \mathrm{~m}$ a.s.l., under logs \& stones, 27-30.12.2013; $1 \sigma^{7}, 3$ of (MNHN), same locality, wet gramineous meadow, 02.01.2014; numerous $\sigma^{7} \sigma^{7}$,,$++\&$ juv. (ZMUM $\rho 2361$ ), National Park Puyehue, Anticura Sector, 4040’S, $72^{\circ} 10^{\prime} \mathrm{W}$, ca $390 \mathrm{~m}$ a.s.1., Nothofagus forest, under logs, 14-20.01.2014, all leg. K. Eskov; 1 (ZMUM $\rho 2392$ ), same locality, ca $390 \mathrm{~m}$ a.s.1., 14 20.01.2014; $4 \sigma^{\top} \sigma^{\top}, 2$ 우 (ZMUM 22393 , p2455), National Park Huerquehue, near Lake Tinquilco, 39¹0'S, $71^{\circ} 44^{\prime} \mathrm{W}$, ca $780 \mathrm{~m}$ a.s.1., 20-26.12.2013, all leg. D. Shcherbakov.

REMARKS. This anthropochore species of European origin has long been recorded in Chile and Argentina [Shelley et al., 2014]. The above new samples have been taken in various habitats, including natural ones.
Brachyiulus pusillus (Leach, 1814)

MATERIAL. 1 juv. (ZMUM p2394), Chile, National Park Huerquehue, near Lake Tinquilco, $39^{\circ} 10^{\prime} \mathrm{S}, 71^{\circ} 44^{\prime} \mathrm{W}$, ca $780 \mathrm{~m}$ a.s.1., Nothofagus forest, litter, 24-26.12.2013, leg. R. Rakitov.

REMARKS. This anthropochore species of European origin has long been recorded in Chile and Argentina [Shelley et al., 2014]. It seems noteworthy that the above new sample has been taken from a natural habitat.

\section{Order Chordeumatida \\ Family Eudigonidae}

Gen. spp.

MATERIAL. 1 ( (ZMUM 2395), Chile, Chiloe Island, National Park Chiloe, $42^{\circ} 072 \mathrm{~S}, 74^{\circ} 012 \mathrm{~W}$, matorral, fern litter, 28.12.2013, leg. D. Takiya; 2 우 (ZMUM 22396 ), Chiloe Island, Senda Darwin Biological Station (ca $15 \mathrm{~km}$ E of Ancud), 41 $1^{\circ} 53^{\prime} \mathrm{S}$, $73^{\circ} 40^{\prime} \mathrm{W}, 25 \mathrm{~m}$ a.s.1., under $\operatorname{logs} \&$ stones, 27-30.12.2013; 1 ㅇ
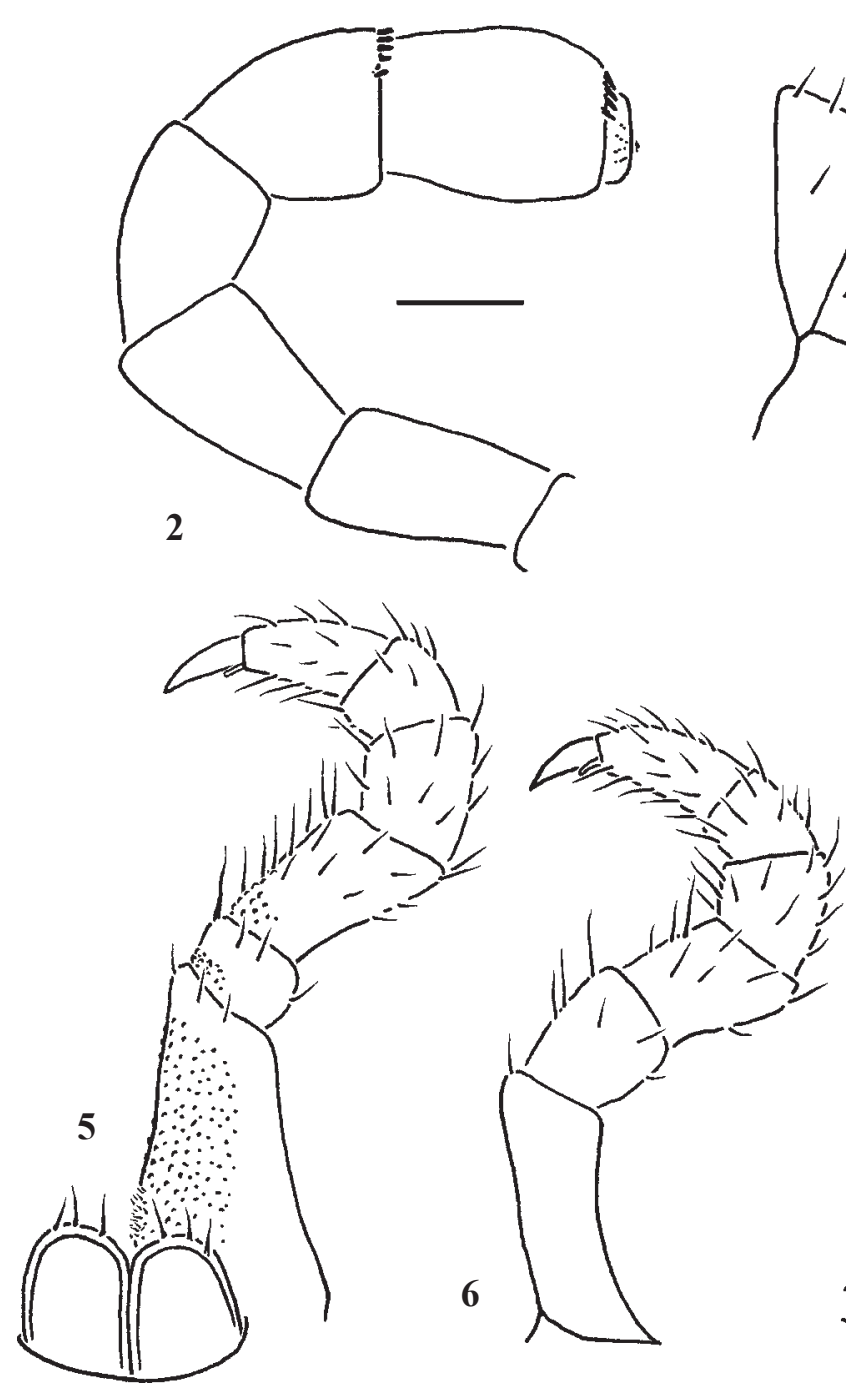

Figs 2-8. Zinagon chilensis (Silvestri, 1903), $\sigma^{7}$ from National Park Huerquehue. 2 - antenna, lateral view; 3 - left half of gnathochilarium, ventral view; 4 - leg 1, anterior view; 5 - leg 2 with penes, caudal view; 6 - leg 3, caudal view; 7 - left anterior gonopod, caudal view; 8 - right posterior gonopod, anterior view. Scale bars: $0.2 \mathrm{~mm}(2-6) \& 0.2 \mathrm{~mm}(7 \& 8)$.

Рис. 2-8. Zinagon chilensis (Silvestri, 1903), ○ из национального парка Нuerquehue. 2 - антенна, сбоку; 3 - левая половина гнатохилярия, снизу; 4 - нога 1, спереди; 5 - нога 2 с пенисами, сзади; 6 - нога 3, сзади; 7 - левый передний гонопод, сзади; 8 - правый задний гонопод, спереди. Масштаб: 0,2 мм (2-6) и 0,2 мм (7 и 8). 
(ZMUM 22397 ), National Park Puyehue, Anticura Sector, $40^{\circ} 40^{\prime} \mathrm{S}$, $72^{\circ} 10^{\prime} \mathrm{W}$, ca $390 \mathrm{~m}$ a.s.l., Nothofagus forest, under logs, 14 20.01.2014; all leg. K. Eskov

REMARKS. Since the new samples contain no $\sigma^{7} \sigma^{7}$, even the genera, let alone species, they belong to cannot be identified. Three genera have hitherto been reported from Chile and the immediately adjacent parts of Argentina: Eudigona Silvestri, 1903 and Ancudia Shear, 1988, both monotypic, and Apodigona Silvestri, 1903 with 3-4 species [Demange, 1963; Shear, 1988]. Of them, Ancudia chepu Shear, 1988 has only been known from near Ancud, Chiloe Island, whereas Apodigona franckei Shear, 1988 from near Puyehue alone.

\section{Order Spirostreptida \\ Family Iulomorphidae}

Zinagon chilensis (Silvestri, 1903) Figs 1-8.

MATERIAL. $1 \sigma^{7}$ (ZMUM 2398), Chile, National Park Huerquehue, near Lake Tinquilco, $39^{\circ} 10^{\prime} \mathrm{S}, 71^{\circ} 44^{\prime} \mathrm{W}$, ca $780 \mathrm{~m}$ a.s.1., stone with moss, 25.12.2013, leg. R. Rakitov; 1 ( same locality, Nothofagus \& Podocarpus forest, litter, 15.01.2014; $4 \mathrm{O}^{7} \mathrm{O}^{7}, 6$ OO (ZMUM 2399 ), National Park Puyehue, Anticura Sector, $40^{\circ} 40^{\prime} \mathrm{S}, 72^{\circ} 10^{\prime} \mathrm{W}$, ca $390 \mathrm{~m}$ a.s.l., Nothofagus forest, under logs, 12-20.01.2014; all leg. K. Eskov.

REMARKS. This genus and species endemic to Chile has recently been redescribed in due detail, based both on type and new material [Korsós \& Read, 2012]. Z. osorno Chamberlin, 1957 is only a junior synonym of $Z$. chilensis, first synonymized by Mauriès [1998], later the synonymy confirmed by Korsós \& Read [2012]. To document the species' identity, as well as to show minor variations in structure and armature of the antennae, gnathochilarium, $\sigma^{7}$ legs 1-3 and gonopods compared to the previous descriptions and illustrations [Silvestri, 1903, 1905a, 1905b; Attems, 1903; Chamberlin, 1957; Demange \& Silva, 1976b; Korsós \& Read, 2012], a habitus picture and new drawings are provided for one of the above fresh samples (Figs 1-8).

\section{Order Spirobolida \\ Family Rhinocricidae}

\section{Argentocricus iguazu sp.n.}

Figs 9-24.

HOLOTYPE $O^{7}$ (ZMUM 2401 ), Argentina, Misiones Prov., National Park Iguazú, $25^{\circ} 412 \mathrm{~S}, 54^{\circ} 262 \mathrm{~W}$, tropical forest, 20.12.2013, leg. K. Eskov.

NAME. To emphasize the type locality; noun in apposition.

DIAGNOSIS. Using the available key to all known species of Argentocricus [Hoffman \& Golovatch, 2012], A. iguazu sp.n. keys out as A. nobilis Verhoeff, 1941, from Santa Fe Province, northern Argentina, but differs in a much smaller body ( $55 \mathrm{~mm}$ versus $86 \mathrm{~mm}$ long), the presence of an additional, superficial stria above the deep premarginal sul-
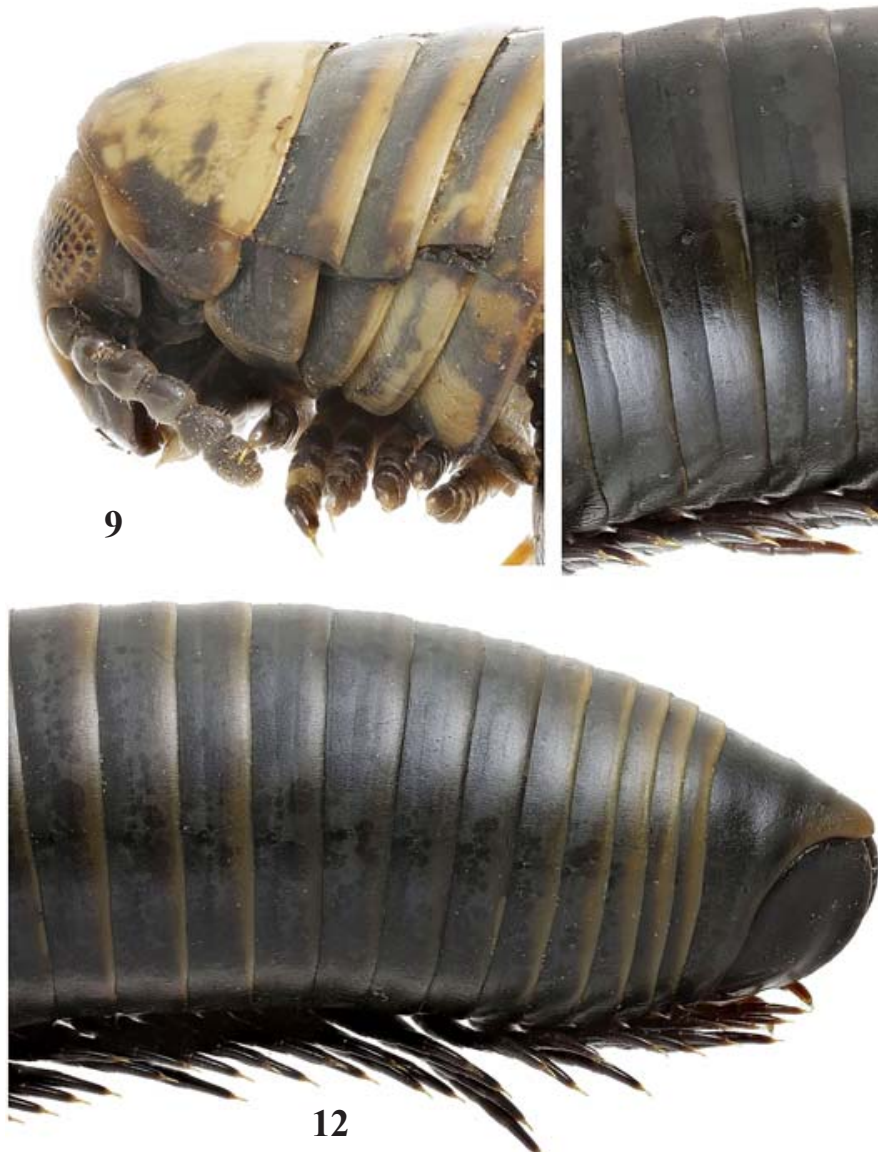
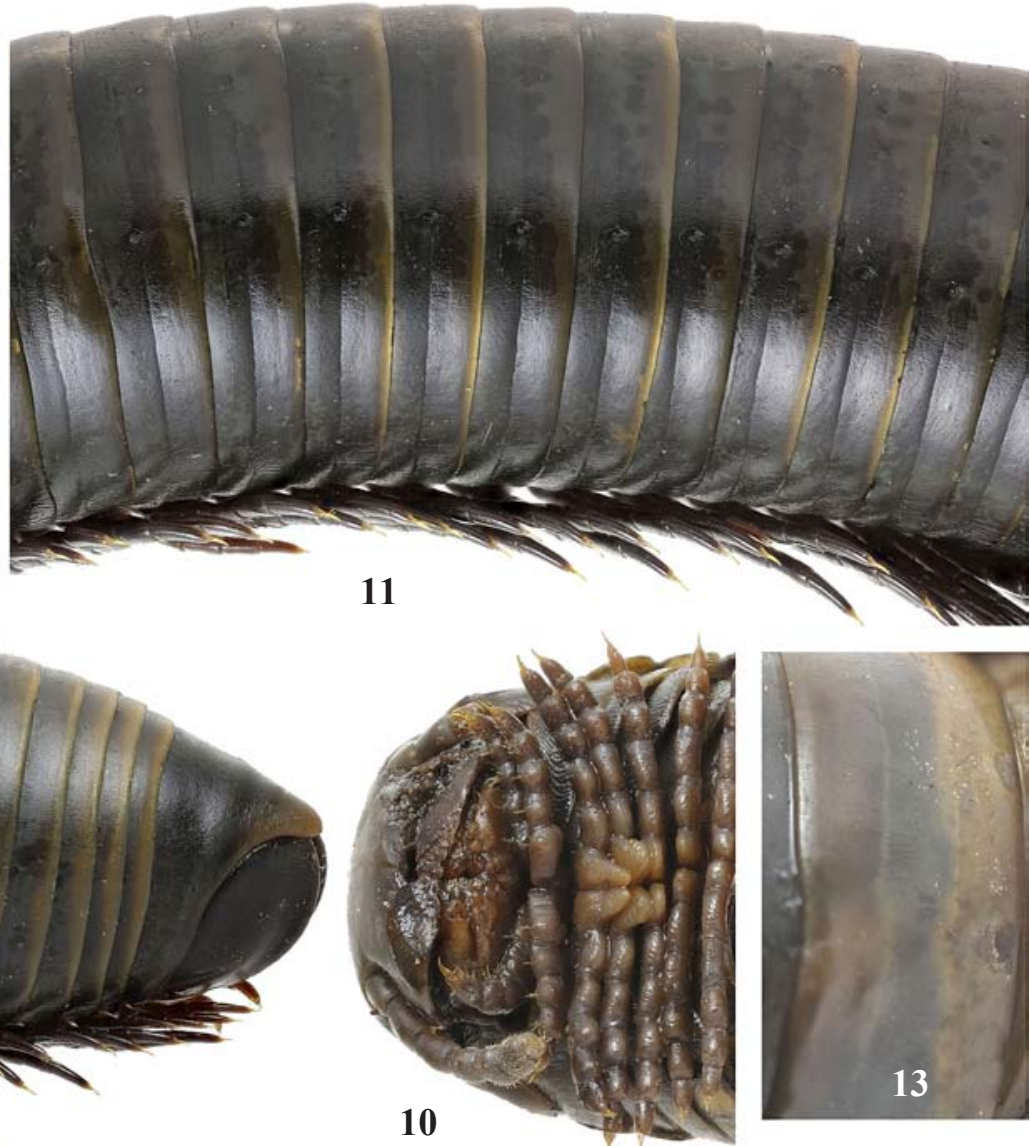

Figs 9-13. Argentocricus iguazu sp.n., holotype. 9-10 - anterior part of body, lateral and caudal views, respectively; 11-12 - middle and posterior parts of body, respectively, lateral view; 13 - scobinae, dorsal view. Pictures by K. Makarov, not taken to scale.

Рис. 9-13. Argentocricus iguazu sp.n., голотип. 9-10 - передняя часть тела, соответственно сбоку и снизу; 11-12 соответственно средняя и задняя части тела, сбоку; 13 - скобины, сверху. Фотографии К. Макарова, без масштаба. 
cus on the lateral lobes of the collum, the acuminate sternal projection (p) and the much shorter inner coxal folds (cf) of the coleopod, a well chitinized bulge (b) on the caudal face of the coleopod telopodite, and a slightly longer, blade-like and less narrow branch lying lateral to the solenomere (sl).

DESCRIPTION. Holotype with 55(0) segments. Length ca $55 \mathrm{~mm}$, diameter $6.0 \mathrm{~mm}$, segments circular. Coloration in alcohol rather uniformly lead-blackish, pattern rather faintly cingulated due to vague, translucent, yellow-brownish rings covering rear halves or margins of metazonae; most of collum and tip of epiproct also yellow-brownish; only labrum, mouthparts and some anterior legs light brown (Figs 9-13). Darker spots at location of ozopores visible along body as a vague blackish horizontal line.

Texture very delicately leathery. Face typical, ocelli in 6 transverse rows, rounded, blackish, poorly distinguished, black spots over dark background, from back forward 8-8$8-7-6-5(=42)$. Collum subtriangular, very broadly rounded laterally, margined anteriorly and laterally, but not caudally, with a deep ventrolateral premarginal sulcus and a shorter superficial stria above (Fig. 9). Antennae of normal form, with numerous apical sensory cones (Fig. 9). Ozopores beginning on segment 6 , located immediately in front of or touching the meso-metazonal suture, which describes an evident semi-circular emargination just above the pore. Metazonae with fine striations ventrolaterally, reduced in size after segment 7 , continuing onto mesozonae to disappear roughly at level of ozopores; prozonae very finely transversely striolate. Pro-, meso- and metazonae subequal in length, divided from each other by very thin line-shaped sutures. Scobinae small (Figs 13-19), starting from segment 6, decreasing in size posteriad from segment 50 , disappearing by segment 52 , separated by about $2.5 \mathrm{X}$ the width of one; arena lunulata with a deep ellipsoidal groove posteriorly; scobinella poorly developed, only half as wide as arena, very finely striolate transversely.
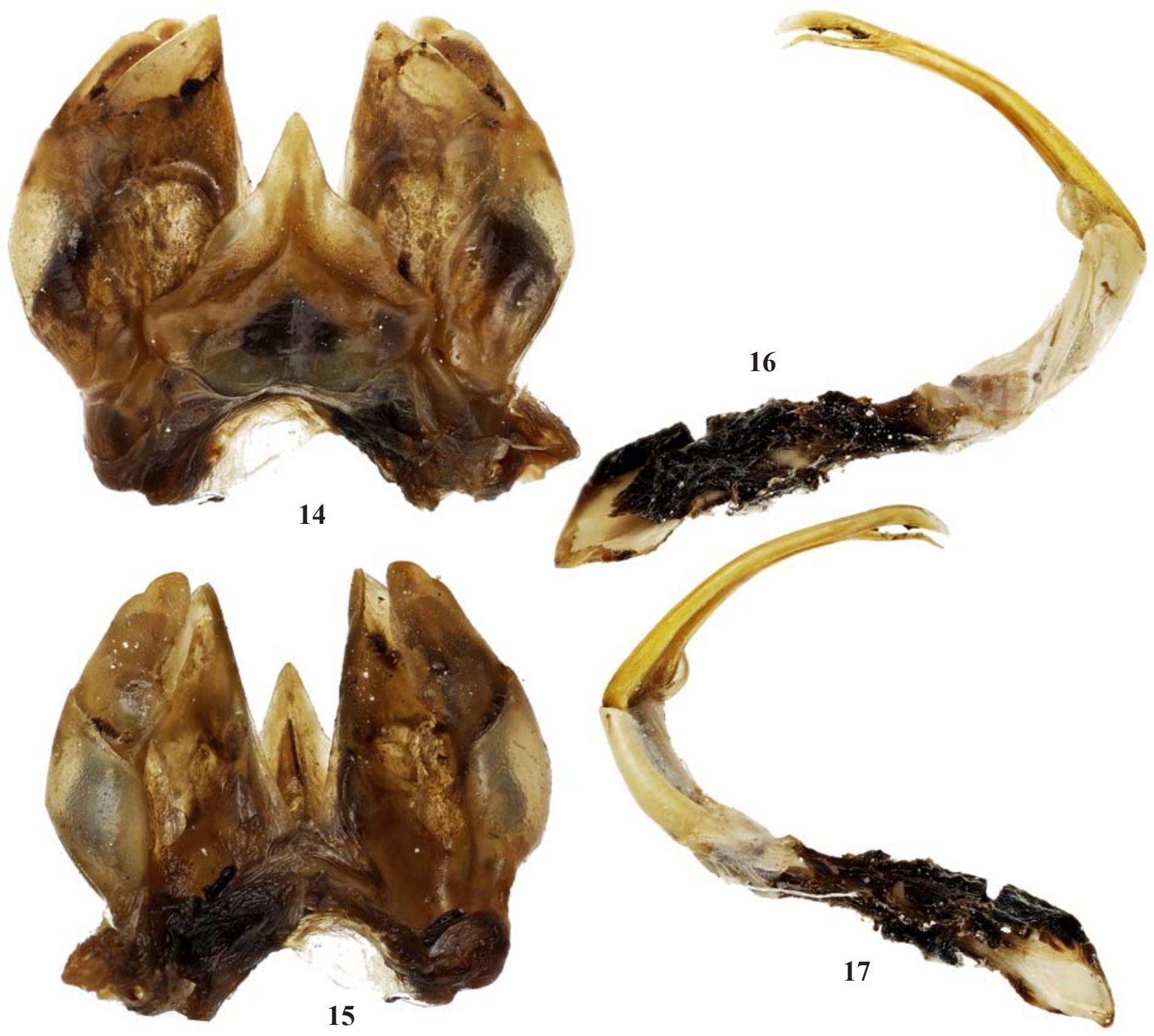

Figs 14-17. Argentocricus iguazu sp.n., holotype. 14-15 - anterior gonopods, anterior and posterior views, respectively; 16-17 - left posterior gonopod, anterior and posterior views, respectively. Pictures by K. Makarov, not taken to scale.

Рис. 14-17. Argentocricus iguazu sp.n., голотип. 14-15 — передние гоноподы, соответственно спереди и сзади; 16-17 — левый задний гонопод, соответственно спереди и сзади. Фотографии К. Макарова, без масштаба. 
Epiproct very short, rounded, straight, barely overhanging above paraprocts (Figs 12 \& 18). Hypoproct transversely semi-circular, paraprocts with only a shallow submarginal depression beside caudal edge, latter rounded, without groove mesally (Fig. 12).

Coxal processes on legs 3 high, coniform, subcontiguous (Figs $10 \& 20$ ), subequal round discs on $4^{\text {th }}$ and $5^{\text {th }}$ (Figs $10 \&$ 21 ), these discs decreasing in size caudad on $6^{\text {th }}$ and $7^{\text {th }}$ (Fig. 20). Podomeres without ventral pads. One or two small spines ventrally, one spine dorsally of claw.

Anterior gonopods, or coleopods (Figs 14, 15, 22 \& 23), with a distinct, sharp, subtriangular, median, sternal projection (p); inner coxal folds (cf) subacuminate apically; caudal face of telopodite with a rather conspicuous rounded bulge (b) mesally in basal one-third extent. Posterior gonopod (Figs $16,17 \& 24$ ) with a slightly shorter, simple, blade-like, narrow branch laterally of a longer, distally slightly sinuate, slender solenomere $(\mathbf{s l})$.
REMARKS. The genus Argentocricus Verhoeff, 1941 has recently been reviewed and shown to encompass eight species confined to southern South America, but ranging only from Bolivia, Paraguay and southern Brazil in the north to northern Argentina in the south [Hoffman \& Golovatch, 2012]. The discovery of $A$. iguazu sp.n., a $9^{\text {th }}$ congener, adds little to the known diagnosis and distribution of Argentocricus, perhaps except for a chitinized, not membranous, bulge on the caudal face of the coleopod telopodite. A membranous bulge or vesicle is generally diagnostic for Argentocricus, whereas a chitinized one is characteristic of only some of 200+ "Rhinocricus" species or subspecies occurring throughout the West Indies and South America [Marek et al., 2003; González-Sponga, 2006; Rodrigues et al., 2012]. However, the assignment of $A$. iguazu sp.n. to Argentocricus is preferred on account of the general structure of both gonopod pairs, including the simple, short and narrow lateral branch of the posterior gonopod, coupled with a coherent distribution pattern [cf. Hoffman \& Golovatch, 2012].
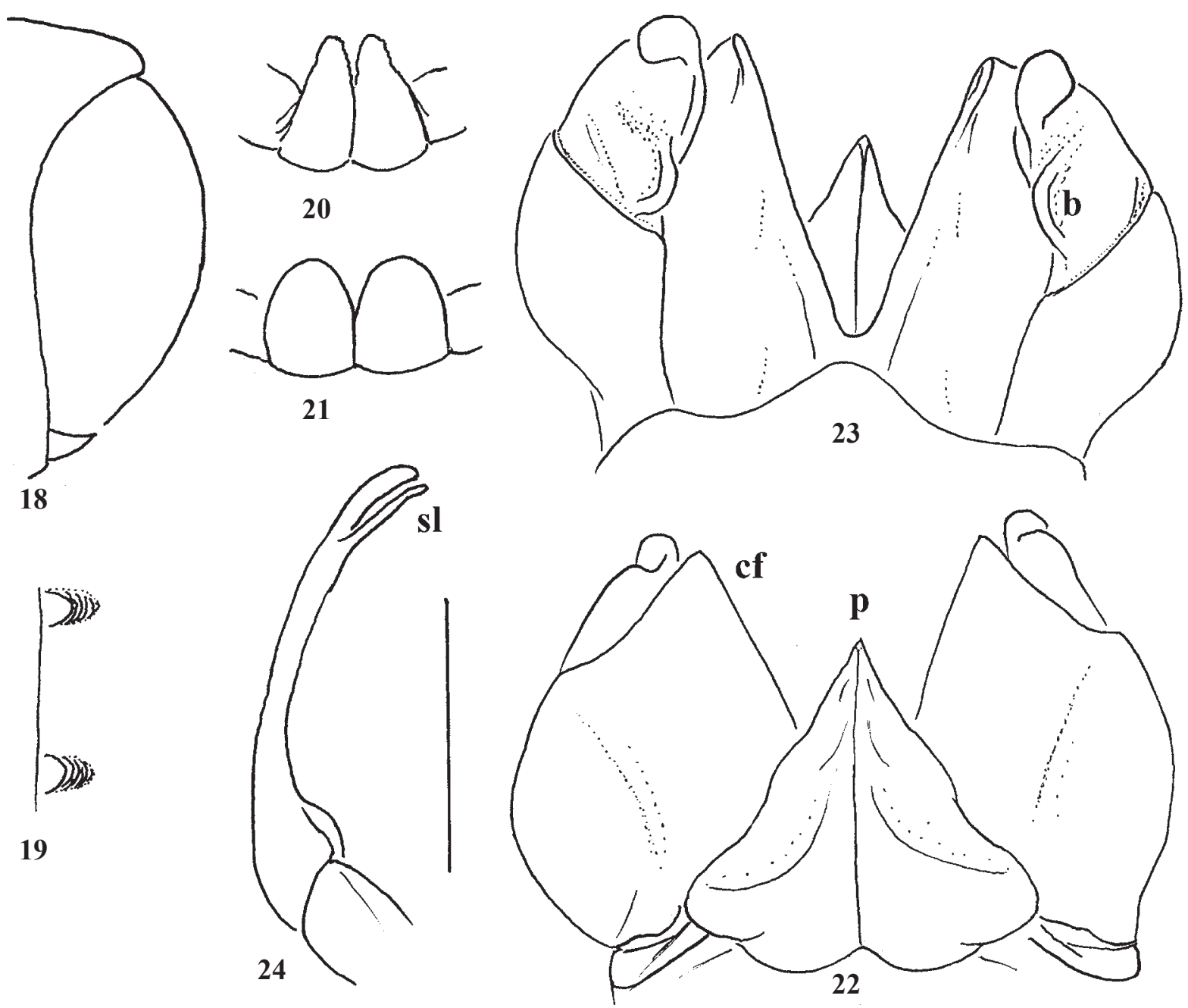

Figs 18-24. Argentocricus iguazu sp.n., holotype. 18 - telson, lateral view; 19 - scobinae, dorsal view; 20 - processes of coxae 3, anteroventral view; 21 - processes of coxae 4, anteroventral view; 22-23 - anterior gonopods, anterior and posterior views, respectively; 24 - left posterior gonopod, anterior view. Scale bar: $2.0 \mathrm{~mm}$. Designations in text.

Рис. 18-24. Argentocricus iguazu sp.n., голотип. 18 - тельсон, сбоку; 19 - скобины, сверху; 20 - отростки тазиков 3 , вид одновременно спереди и снизу; 21 - отростки тазиков 4, вид одновременно спереди и снизу; 22-23 - передние гоноподы, соответственно спереди и сзади; 24 - левый задний гонопод, спереди. Масштаб: 2,0 мм. Обозначения в тексте. 
Order Polyzoniida

Family Siphonotidae

Burinia parguaensis (Mauriès \& Silva, 1971)

Figs 25-29.
MATERIAL. 10 , 1 9 (ZMUM 02403 ), Chile, National Park Nahuelbuta, Pehuenco, $37^{\circ} 50^{\prime} \mathrm{S}, 73^{\circ} 01^{\prime} \mathrm{W}$, ca $1120 \mathrm{~m}$ a.s.l., Nothofagus \& Araucaria forest, under logs \& stones, 22-26.01.2014; 1 $\sigma^{7}, 6$ 오 (ZMUM 2404 ), National Park Puyehue, Anticura Sector, $40^{\circ} 40^{\prime} \mathrm{S}, 72^{\circ} 10^{\prime} \mathrm{W}$, ca $390 \mathrm{~m}$ a.s.1., Nothofagus forest, under logs, 14-20.01.2014, all leg. K. Eskov; 2 우 (MNHN), same locality,

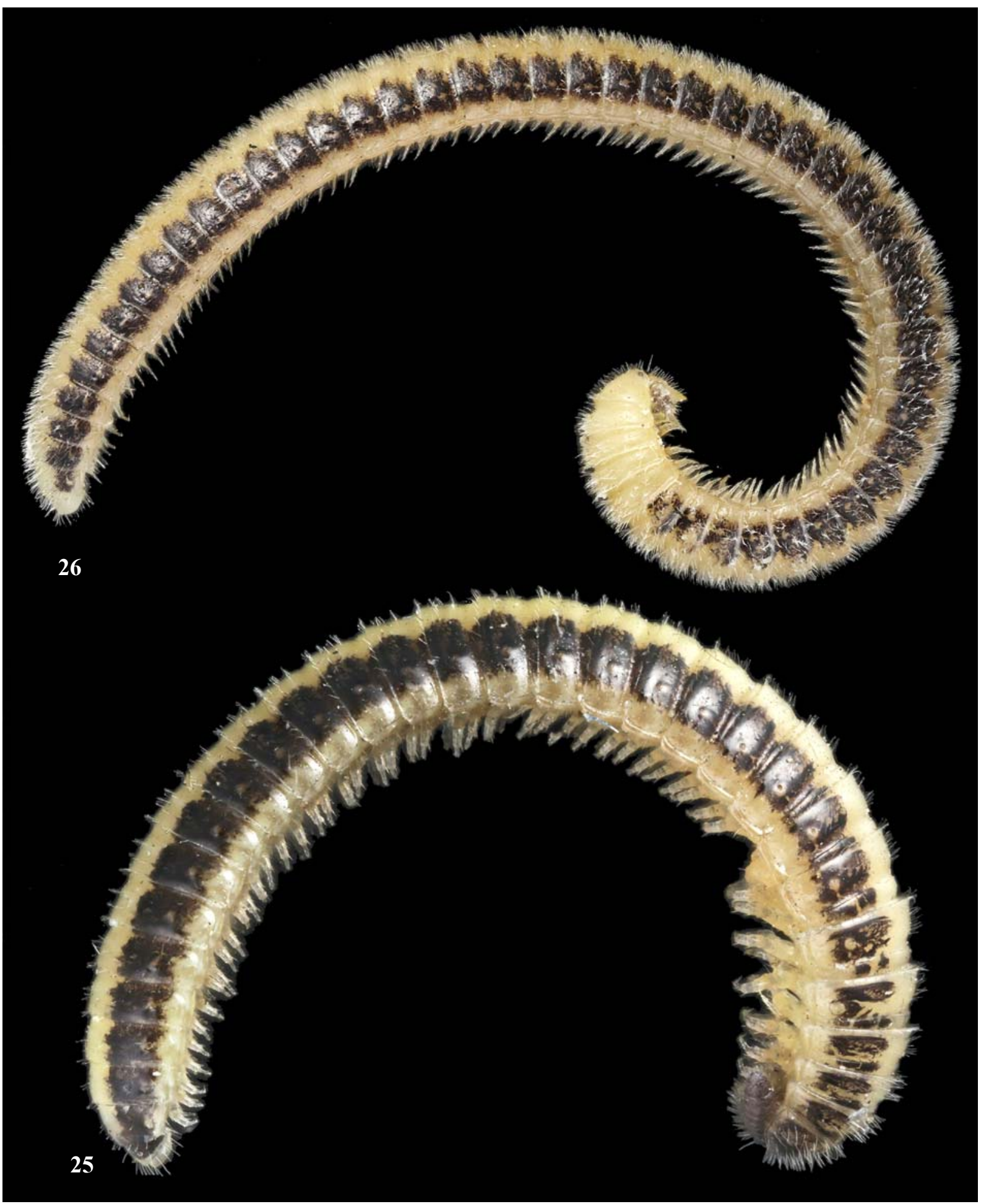

Figs 25-26. Habitus of Burinia parguaensis (Mauriès \& Silva, 1971), lateral view: 25 - $0^{7}$ from National Park Nahuelbuta; 26 — 9 from National Park Puyehue.

Рис. 25-26. Внешний вид Burinia parguaensis (Mauriès \& Silva, 1971), сбоку: 25 — ○7 из национального парка Nahuelbuta; 26 ㅇ из национального парка Puyehue. 
16-20.01.2014, leg. R. Rakitov; 1 ○ $^{7}, 1$ q (ZMUM p2402), National Park Puyehue, Antillanca Sector, $40^{\circ} 46^{\prime} \mathrm{S}, 72^{\circ} 12^{\prime} \mathrm{W}$, ca $1060 \mathrm{~m}$ a.s.1., Nothofagus \& Podocarpus forest, moss, 17.01.2014; $2 O^{7} O^{7}, 1$ juv. (ZMUM 2406 ), National Park Alerce Andino, Sargazo Sector, $41^{\circ} 30^{\prime} \mathrm{S}, 72^{\circ} 37^{\prime} \mathrm{W}$, ca $350 \mathrm{~m}$ a.s.l., Nothofagus \& Podocarpus forest, 5-11.01.2014; 2 우 (ZMUM p2407), Chiloe Island, Senda Darwin Biological Station (ca $15 \mathrm{~km} E$ of Ancud), $41^{\circ} 53^{\prime} \mathrm{S}, 73^{\circ} 40^{\prime} \mathrm{W}, 25 \mathrm{~m}$ a.s.1., 27-30.12.2013; 1 juv. (ZMUM p2408), same locality, wet gramineous meadow, litter, 2.01.2014, all leg. K. Eskov.

REMARKS. The genus Burinia Attems, 1926 is very close if not identical to Siphonotus Brandt, 1837. Hoffman [1977, 1980] treated both separately, whereas Mauriès \& Silva [1971] and Mauriès [1998] admit only the latter genus as being valid. Here I follow Hoffman in considering all indigenous Chilean species of Polyzoniida as belonging in Burinia. In addition, Pampiconus Chamberlin, 1957 is long known as a junior subjective synonym of Burinia [e.g. Hoffman, 1980].

Altogether, nine Burinia species have hitherto been reported from Chile alone [Chamberlin, 1957; Mauriès \& Silva, 1971], including three originally described in Pampiconus: P. mundus Chamberlin, 1957, P. ovallenus Chamber- lin, 1957 (the type species) and P. primitivus Chamberlin, 1957. Mauriès \& Silva [1971] treat the latter trio as nomina dubia, possibly partly even based on immature specimens and thus remaining unidentifiable. So they considered as fairly well documented only the six species they described and keyed by themselves, all in Siphonotus: $S$. contulmensis Mauriès \& Silva, 1971, S. demangei Mauriès \& Silva, 1971, S. jacqueminae Mauriès \& Silva, 1971, S. parguaensis Mauriès \& Silva, 1971, S. roseus Mauriès \& Silva, 1971 and $S$. saizi Mauriès \& Silva, 1971. Further Burinia species are only known from southern Africa and Brazil [Hoffman, 1980].

Among the Chilean congeners, however, only three colour patterns are easily distinguished: (1) two paramedian, rather sublateral, dark, brown to blackish stripes separated by a broad, pink or yellow, axial stripe along most of or entire body (B. munda, B. parguaensis and B. jacqueminae); (2) an axial, brown to blackish stripe along most of or entire body, with sides remaining pink or yellow ( $B$. primitiva, $B$. rosea and $B$. contulmensis); and (3) light yellow to mottled yellowbrown throughout, showing no particular pattern ( $B$. ovalle$n a, B$. saizi and B. demangei).

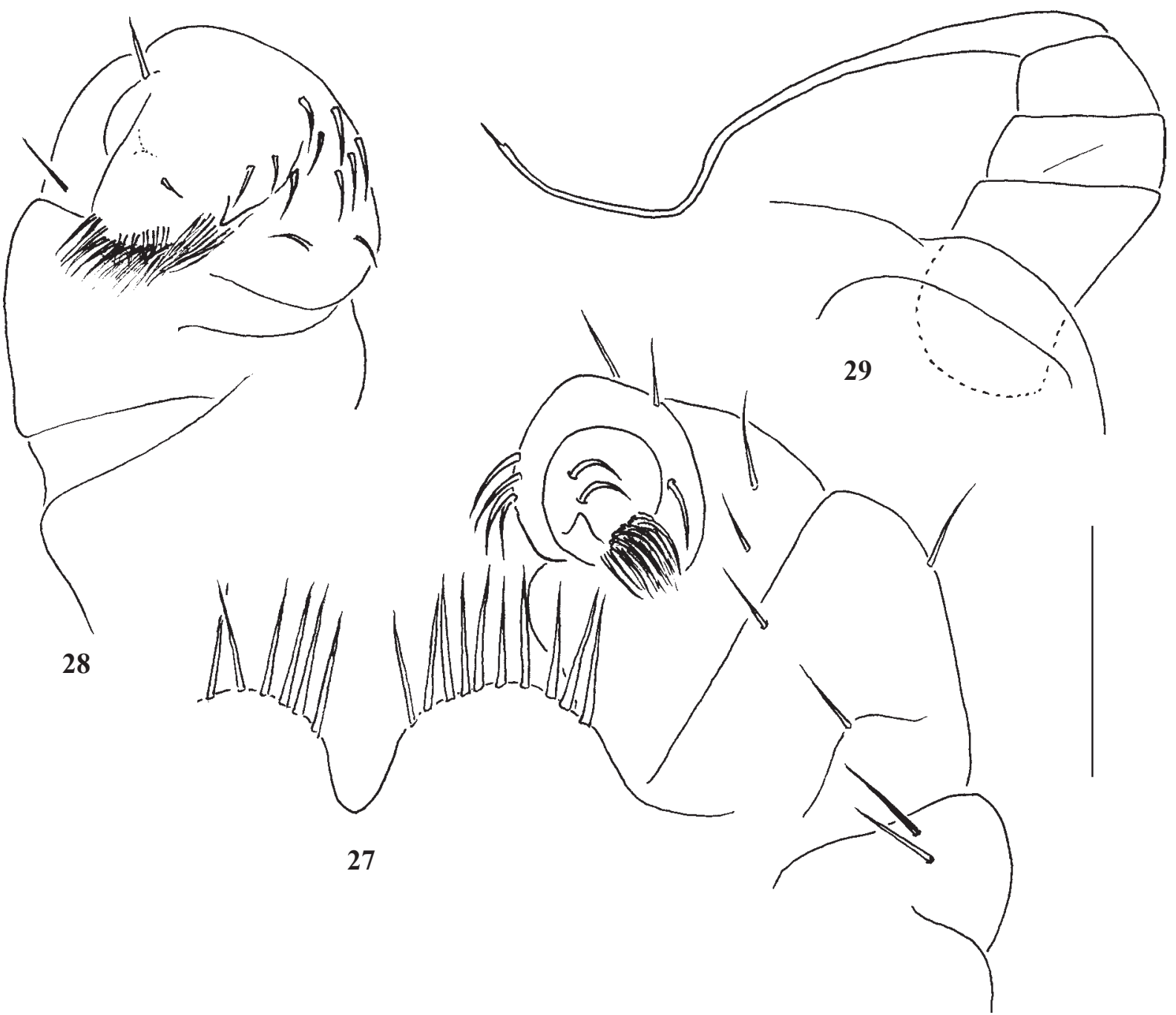

Figs 27-29. Burinia parguaensis (Mauriès \& Silva, 1971), O7 from National Park Nahuelbuta. 27-28 — anterior gonopods, anterior and ventrocaudal views, respectively; 29 - left posterior gonopod, anterior view. Scale bar: $0.1 \mathrm{~mm}$.

Рис. 27-29. Burinia parguaensis (Mauriès \& Silva, 1971), О7 из национального парка Nahuelbuta. 27-28 - передние гоноподы, соответственно спереди и одновременно сзади и снизу; 29 - левый задний гонопод, спереди. Масштаб: 0,1 мм. 
I refer the above new samples from Chile to B. parguaensis, because they all show basically the same, only slightly variable colour pattern which ranges from leaving the anterior end of the body completely flavous to entirely fuscous like the sublateral stripes (cf. Figs 25-26), coupled with a particularly convex collum which is nearly as high as head length, very broad, regularly, but moderately strongly attenuating gonapophyses on $\sigma^{7}$ coxae 2 , probably a quite densely setose tip of the anterior gonopod telopodite which is devoid of a prominent claw, and perhaps a particularly long, flagelloid terminal segment of the posterior gonopod (Figs 27-29). In contrast, the anterior gonopods in $B$. munda show a very prominent terminal claw [Chamberlin, 1957], whereas the collum in $B$. jacqueminae is considerably less strongly convex while the gonapophyses on $\sigma^{7}$ coxae much smaller [Mauriès \& Silva, 1971]. Interestingly, the gonopod structure in the Burinia species from Chile appears to be rather monoto- nous, with obviously only very few reliable distinguishing characters being involved.

B. parguaensis appears to be widespread across the southern parts of Chile (Map), ranging from Chiloe Island in the south to Nahuelbuta in the north [see also Mauriès \& Silva, 1971]. At Nahuelbuta it occurs sympatrically or even syntopically together with both $B$. contulmensis and B. saizi.

\section{Burinia contulmensis (Mauriès \& Silva, 1971)} Figs 30-34.

MATERIAL. $20^{7} \sigma^{7}, 3$ 우 (ZMUM $\left.\rho 2409\right)$, Chile, National Park Nahuelbuta, Pehuenco, $37^{\circ} 50^{\prime} \mathrm{S}, 73^{\circ} 01^{\prime} \mathrm{W}$, ca $1120 \mathrm{~m}$ a.s.l., Nothofagus \& Araucaria forest, under logs \& stones, 22-26.01.2014, leg. K. Eskov.

REMARKS. This species occurs sympatrically if not syntopically together with both $B$. parguaensis and B. saizi (see above), being easily recognizable by its colour pattern

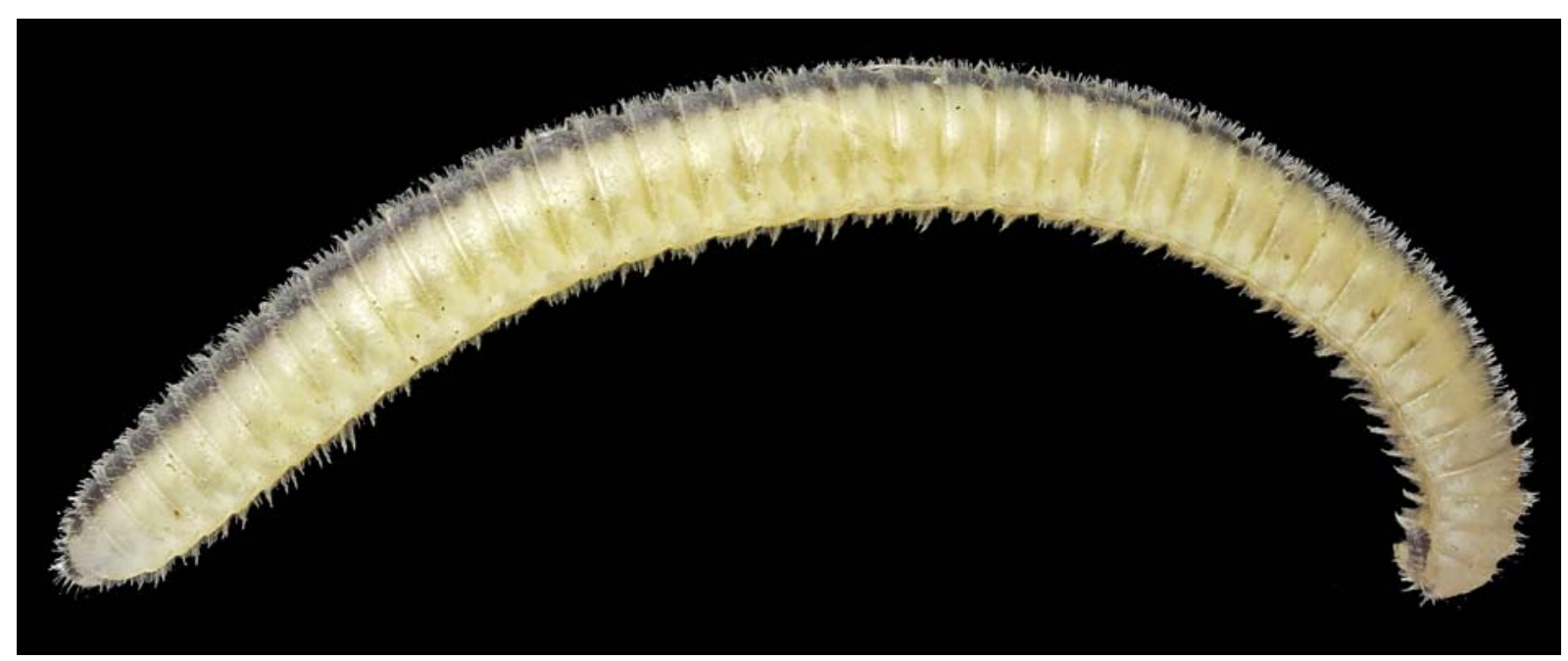

Fig. 30. Habitus of Burinia contulmensis (Mauriès \& Silva, 1971), 9 from National Park Nahuelbuta, lateral view.

Рис. 30. Внешний вид Burinia contulmensis (Mauriès \& Silva, 1971), ф из национального парка Nahuelbuta, сбоку.

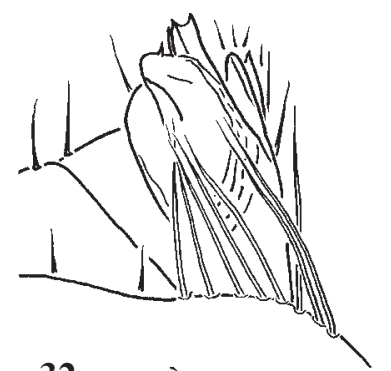

32
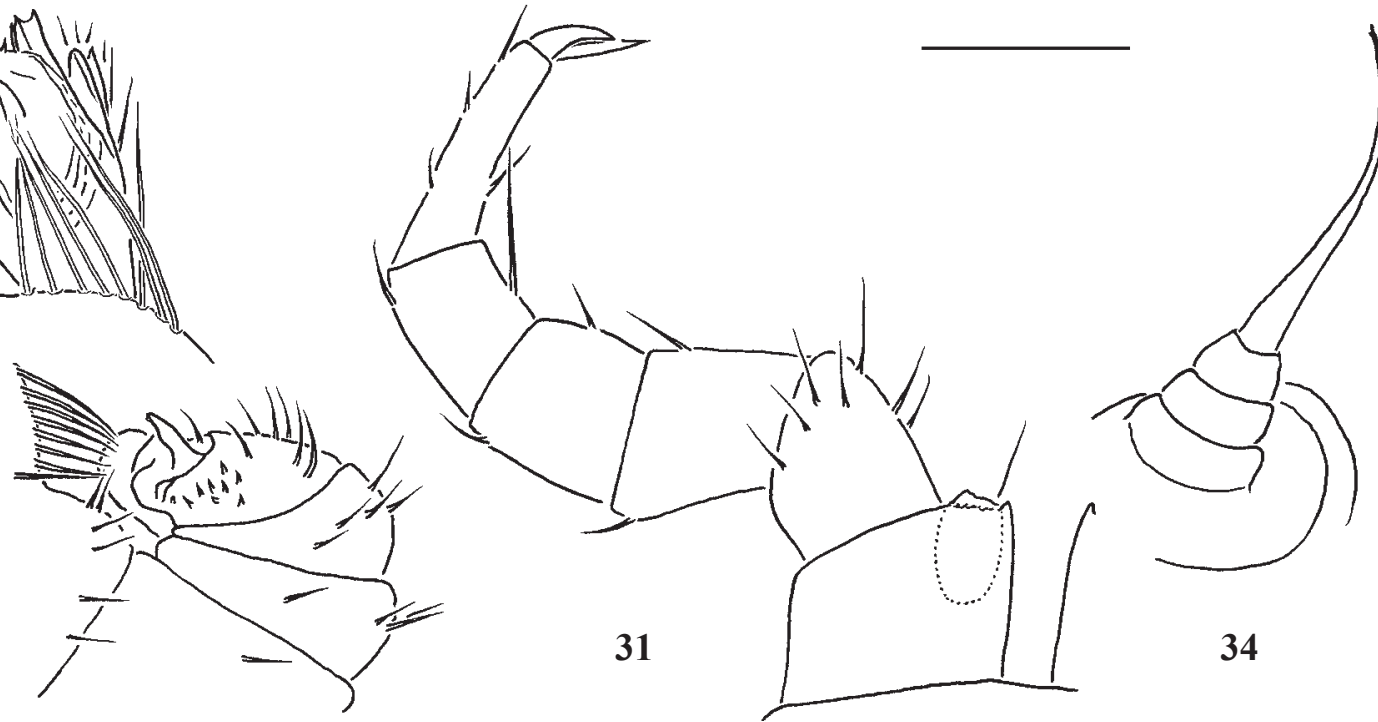

Figs 31-34. Burinia contulmensis (Mauriès \& Silva, 1971), $0^{7}$ from National Park Nahuelbuta. 31 - leg 11, anterior view; 32-33 anterior gonopods, caudomesal and anterior views, respectively; 34 - left posterior gonopod, subventral view. Scale bar: $0.1 \mathrm{~mm}$.

Pис. 31-34. Burinia contulmensis (Mauriès \& Silva, 1971), О7 из национального парка Nahuelbuta. 31 — нога 11, спереди; 32-33передние гоноподы, соответственно одновременно сзади и изнутри, а также спереди; 34 - левый задний гонопод, почти снизу. Масштаб: 0,1 мм. 
(Fig. 30), coupled with a rather complex structure of legs 11 and gonopods (Figs 31-34). I refer the above new samples to $B$. contulmensis, because the lateral parts of the terga are yellow, not pink as in $B$. rosea, whereas the gonopods are far more complex than in $B$. primitiva where they are probably known only in an underdeveloped, juvenile condition [cp. Chamberlin, 1957; Mauriès \& Silva, 1971].

$B$. contulmensis has hitherto been reported only from central Chile [Mauriès \& Silva, 1971], whence also the new samples derive (Map).

\section{Burinia saizi (Mauriès \& Silva, 1971)}

Figs 35-39.

MATERIAL. $1 \sigma^{7}, 1$ (ZMUM $\left.\rho 2410\right)$, Chile, National Park Nahuelbuta, Pehuenco, $37^{\circ} 50^{\prime} \mathrm{S}, 73^{\circ} 01^{\prime} \mathrm{W}$, ca $1120 \mathrm{~m}$ a.s.1., Nothofagus \& Araucaria forest, under logs \& stones, 2226.01.2014, leg. D. Shcherbakov.
REMARKS. This species is well recognizable [Mauriès \& Silva, 1971] through being uniformly light yellow brownish throughout (devoid of a pattern), coupled with quite narrow gonapophyses on $\sigma^{7}$ coxae 2 and a rounded apical lobe of the posterior gonopod (Figs 3539). All previous records are only known from somewhat north of Santiago [Mauriès \& Silva, 1971]. At Nahuelbuta this species occurs sympatrically or even syntopically together with both $B$. contulmensis and $B$. parguaensis (Map).

I refer the above new samples to $B$. saizi, because they differ clearly from $B$. demangei in a far less strongly convex collum, from $B$. ovallena by the anterior gonopods being much more complex and non-unciform (again possibly an underdeveloped, juvenile condition so far known in the latter species).

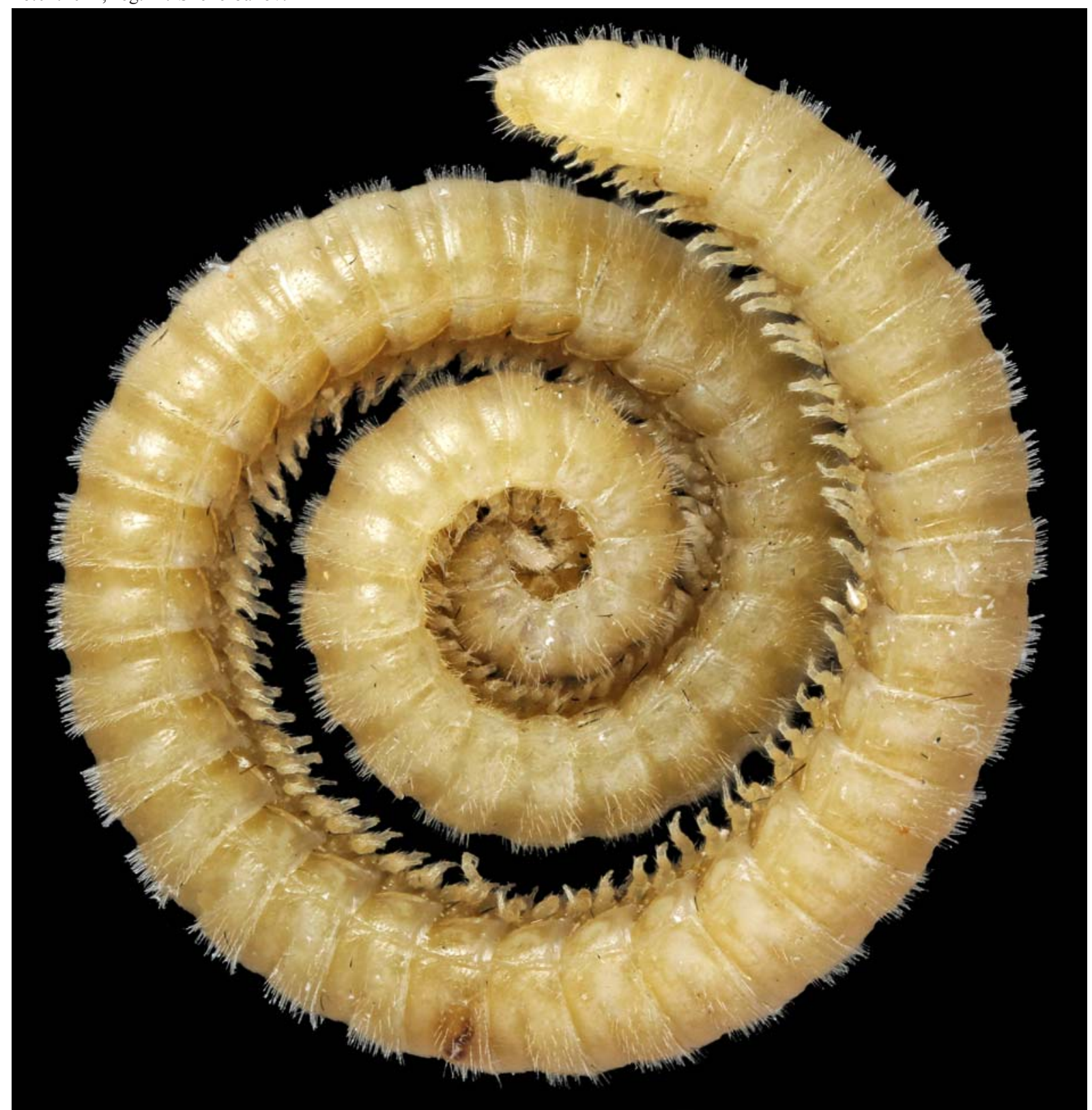

Fig. 35. Habitus of Burinia saizi (Mauriès \& Silva, 1971), 9 from National Park Nahuelbuta, lateral view.

Рис. 35. Внешний вид Burinia saizi (Mauriès \& Silva, 1971), из национального парка Nahuelbuta, сбоку. 


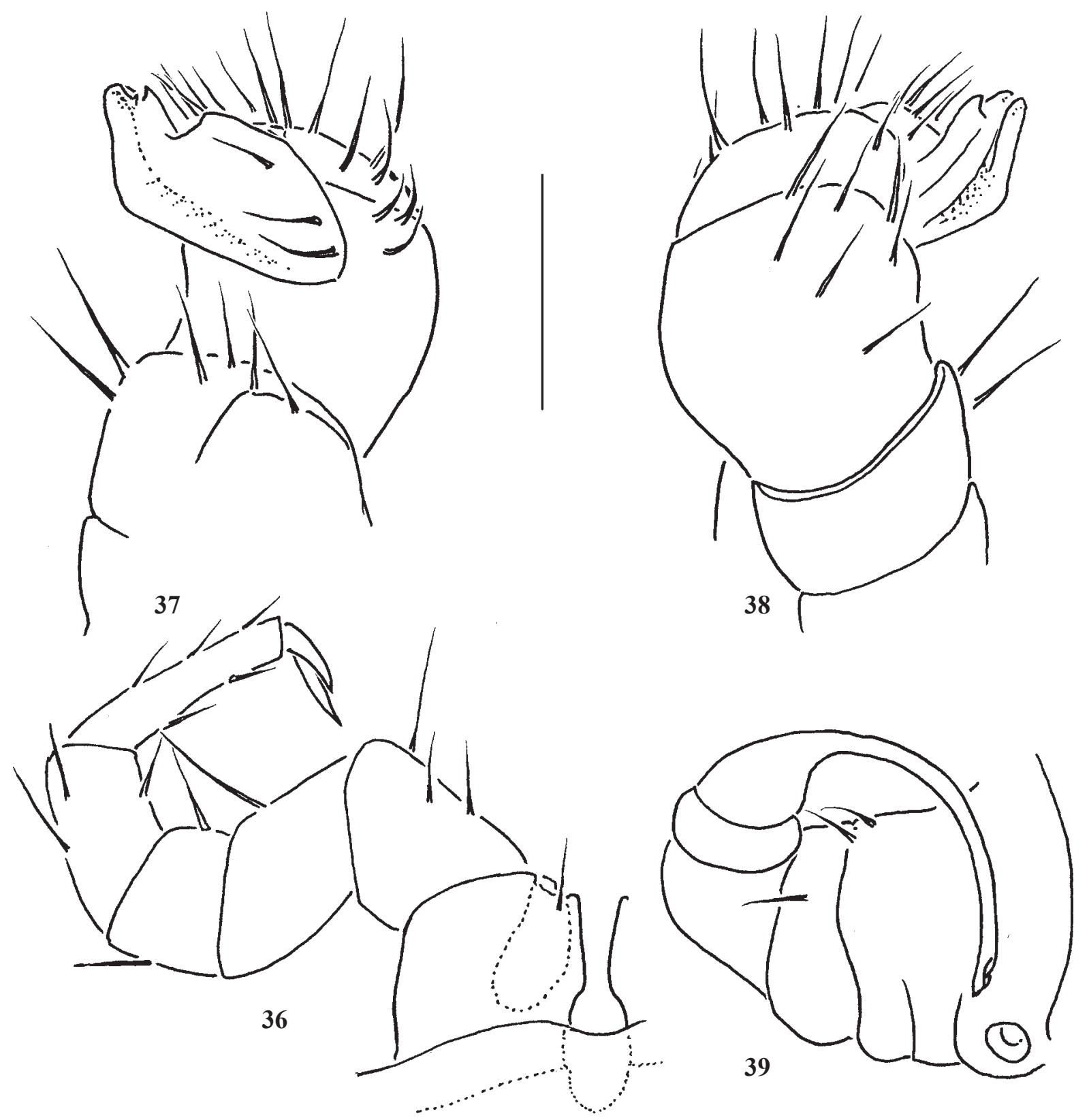

Figs 36-39. Burinia saizi (Mauriès \& Silva, 1971), o' from National Park Nahuelbuta. 36 - leg 11, anterior view; 37 — 38 — left anterior gonopod, caudal and anterior views, respectively; 39 - right posterior gonopod, subventral view. Scale bar: $0.1 \mathrm{~mm}$.

Рис. 36-39. Burinia saizi (Mauriès \& Silva, 1971), о7 из национального парка Nahuelbuta. 36 — нога 11, спереди; 37-38 — левый передний гонопод, соответственно сзади и спереди; 34 - правый задний гонопод, почти снизу. Масштаб: 0,1 мм.

\section{Order Polydesmida \\ Family Dalodesmidae}

Pleonarius omalonotus Silvestri, 1903

Figs 40-50.

MATERIAL. $3 \sigma^{7} \sigma^{7}, 1$ (ZMUM $\left.\rho 2362\right)$, Chile, National Park Puyehue, Anticura Sector, $40^{\circ} 40^{\prime} \mathrm{S}, 72^{\circ} 10^{\prime} \mathrm{W}$, ca $390 \mathrm{~m}$ a.s.1., Nothofagus forest, under logs, 14-20.01.2014; $1 \sigma^{7}$ (MNHN), National Park Nahuelbuta, $37^{\circ} 50^{\prime} \mathrm{S}, 7^{\circ} 01^{\prime} \mathrm{W}$, ca $1120 \mathrm{~m}$ a.s.1. Nothofagus \& Araucaria forest, under logs \& stones, 22-26.01.2014, all leg. K. Eskov.

REMARKS. Pleonarius Attems, 1898 is a small Chilean genus [Attems, 1898, 1914, 1940; Silvestri, 1903, 1905a, b;
Hoffman, 1980] characterized by a peculiar, complex gonopod conformation and a special ozopore formula: 5, 7, 9-19. It contains only two species, of which $P$. omalonotus has sometimes [e.g. Attems, 1940; Chamberlin, 1957] been treated as only a subspecies of the type species $P$. pachyskeles Attems, 1898. Here I follow Demange \& Silva [1976b] who, based on type material, depicted the gonopods of both these species in due detail.

New illustrations are provided here to document the identity of the new samples (Figs 40-50), including the peculiar gonopod conformation and smooth metaterga (= absence of metatergal bosses). Both these features are highly characteristic of the species. The gonopods (Figs 45-50) 


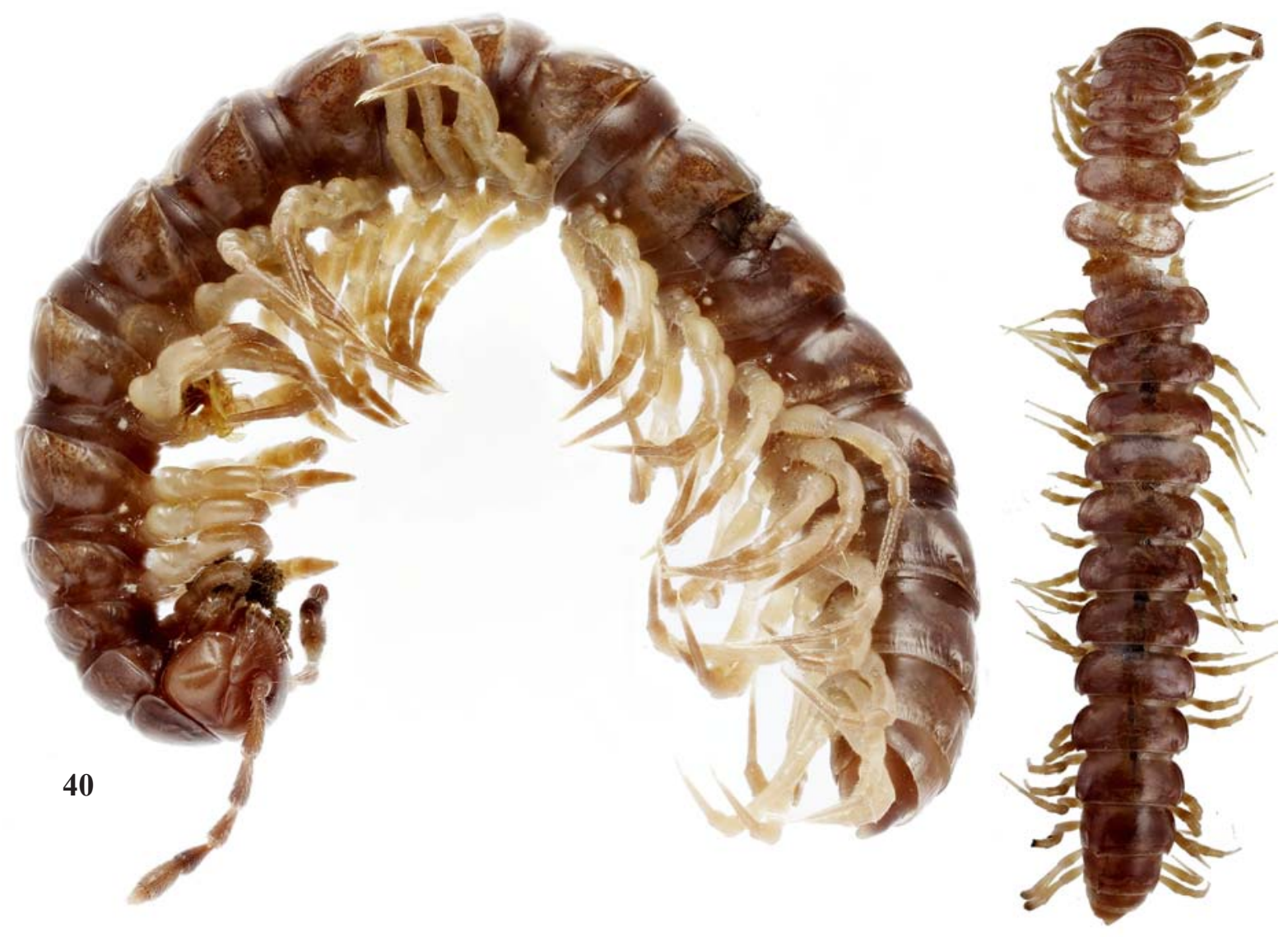

41

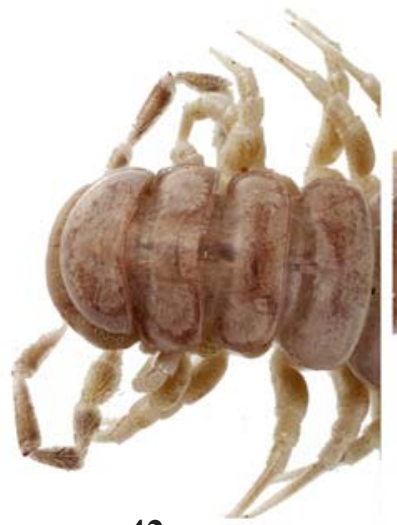

42

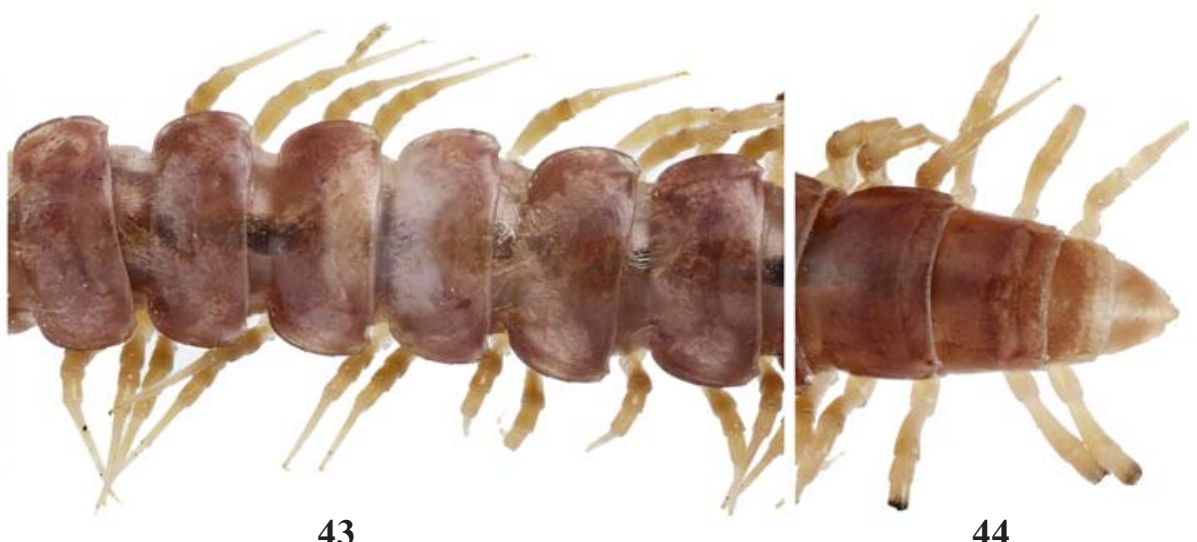

43

Figs 40-44. Pleonarius omalonotus Silvestri, 1903, ○ from National Park Nahuelbuta (40) and $\bigcirc^{7}$ from National Park Puyehue (4144). 40-41 — habitus, lateral and dorsal views, respectively; 42, 43-44 - anterior, middle and caudal parts of body, respectively, dorsal view. Pictures by K. Makarov, not taken to scale.

Рис. 40-44. Pleonarius omalonotus Silvestri, 1903, О $\sigma^{7}$ из национального парка Nahuelbuta (40) и $\bigcirc^{\top}$ из национального парка Puyehue (41-44). 40-41 - общий вид, соответственно сбоку и сверху; 42, 43-44- соответственно передняя, средняя и задняя части тела, сверху. Фотографии К. Макарова, без масштаба.

Figs 45-48. Gonopodial block of Pleonarius omalonotus Silvestri, 1903, Ơ from National Park Puyehue, lateral or sublateral views. Pictures by K. Makarov, not taken to scale.

Рис. 45-48. Гоноподиальный блок Pleonarius omalonotus Silvestri, 1903, О7 из национального парка Рuуеһuе, сбоку или почти сбоку. Фотографии К. Макарова, без масштаба. 

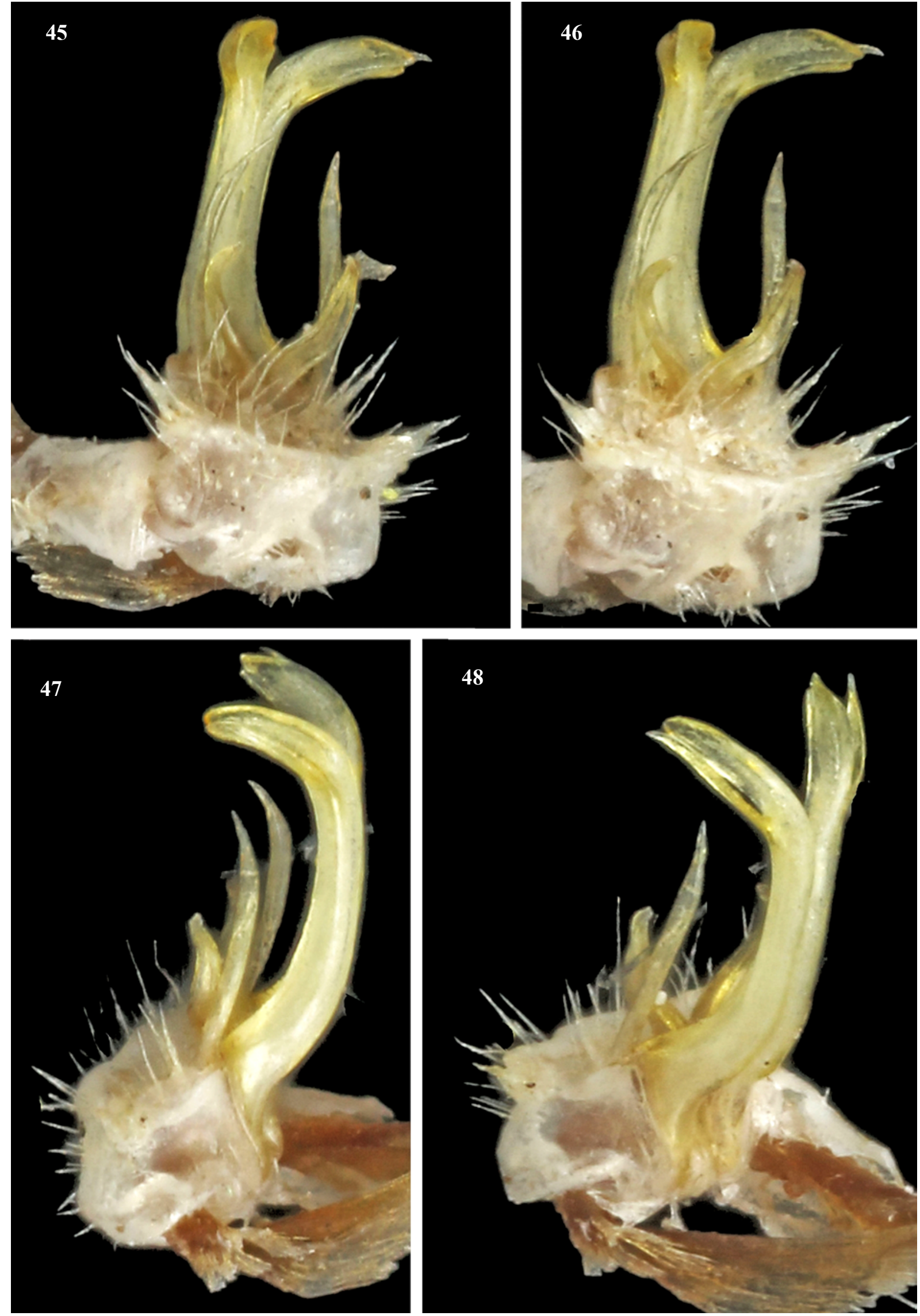

48

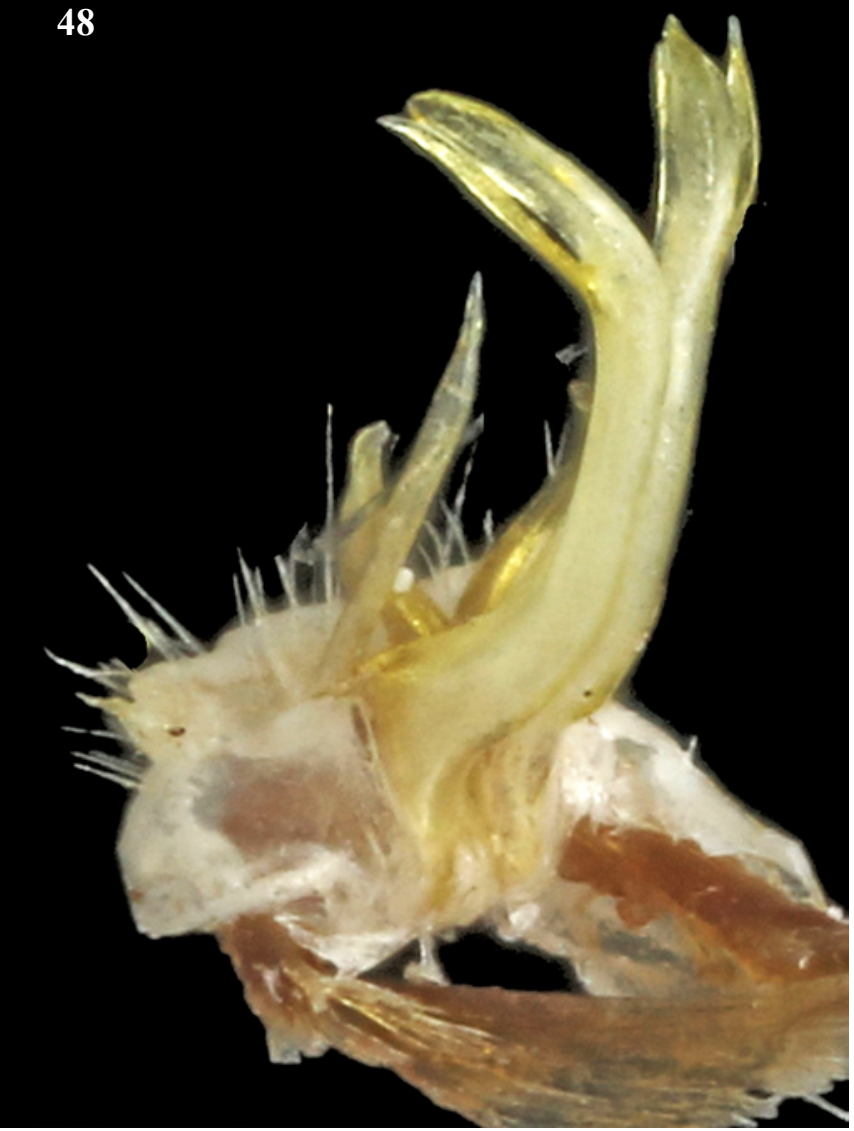



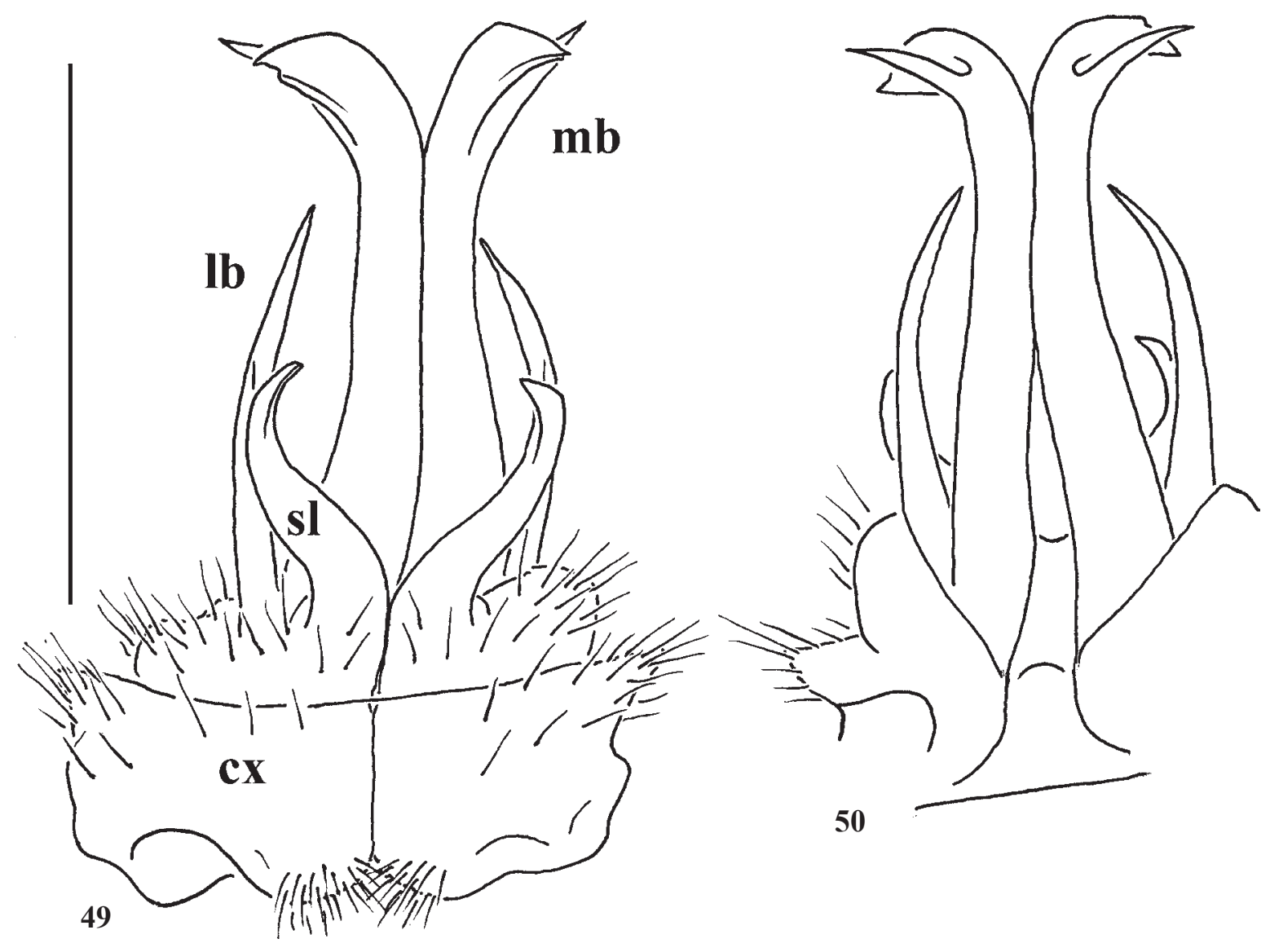

Figs 49-50. Gonopodial block of Pleonarius omalonotus Silvestri, 1903, Ơ from National Park Puyehue, anterior and posterior views, respectively. Scale bar: $0.5 \mathrm{~mm}$. Designations in text.

Рис. 49-50. Гоноподиальный блок Pleonarius omalonotus Silvestri, 1903, о7 из национального парка Рuyehue, соответственно спереди и сзади. Масштаб: 0,5 мм. Обозначения в тексте.

are contiguous medially, being fused only in the coxal region (cx). Solenomeres (sl) are curved, paramedian, contiguous branches lying in front of much higher, similarly simple, but suberect lateral branches (lb) flanking particularly strong medial branches (mb) with diverging, complex, bifurcate tips.

The species has hitherto been known only from Coipué $\left(35^{\circ} 15^{\prime} 0^{\prime \prime} \mathrm{S}, 72^{\circ} 4^{\prime} 0^{\prime \prime} \mathrm{W}\right)$, Constitución, Talca, central Chile. The new samples derive from southern Chile (Map), demonstrating a far vaster distribution of $P$. omalonotus in the country.

\section{Monenchodesmus inermis Silvestri, 1903} Figs 51-60.

= Monenchodesmus inermis nahuelhuapiensis Schubart, 1954, syn.n. = Monenchodesmus tiganus Chamberlin, 1957, syn.n.

MATERIAL. $1 \mathrm{O}^{7}$ (MNHN), Chile, National Park Puyehue, Anticura Sector, $40^{\circ} 40^{\prime} \mathrm{S}, 72^{\circ} 10^{\prime} \mathrm{W}$, ca $390 \mathrm{~m}$ a.s.1., Nothofagus forest, under logs, 14-20.01.2014; $1 \sigma^{7}, 1$ ㅇ (ZMUM 2400 ), National Park Alerce Andino, Sargazo Sector, 41 $30^{\circ}$ S, $72^{\circ} 37^{\prime} \mathrm{W}$, ca $350 \mathrm{~m}$ a.s.1., Nothofagus \& Podocarpus forest, under logs, 5 11.01.2014; 5 우, 1 juv. (ZMUM 2411 , 2412 ), National Park Nahuelbuta, Pehuenco, $37^{\circ} 50^{\prime} \mathrm{S}, 73^{\circ} 01^{\prime} \mathrm{W}$, ca $1120 \mathrm{~m}$ a.s.1., Nothofagus \& Araucaria forest, under logs \& stones, 22-26.01.2014, all leg. K. Eskov.

REMARKS. The genus Monenchodesmus Silvestri, 1903 has hitherto been considered as encompassing six species or subspecies [Hoffman, 1980] which are mostly confined to Chile. The above new samples unquestionably belong to $M$. inermis, as their gonopods are identical to those which Demange \& Silva [1976b] very clearly depicted from a syntype from Coipué $\left(35^{\circ} 15^{\prime} 0 " \mathrm{~S}\right.$, $\left.72^{\circ} 4^{\prime} 0^{\prime \prime} \mathrm{W}\right)$, Constitución, Talca, central Chile. Moreover, there is no doubt that, based on the original descriptions and gonopod drawings alone, both $M$. tiganus Chamberlin, 1957 and M. inermis nahuelhuapiensis Schubart, 1954 are junior subjective synonyms of $M$. inermis, syn.n. [cf. Schubart, 1954; Chamberlin, 1957]. In addition, the $M$. tiganus types $\left(1 \sigma^{7}, 1+\right)$ originated from near Puyehue, thus reinforcing the above synonymy. As a result, $M$. inermis, one of the largest and most conspicuous species of Dalodesmidae in the present collection (Figs 51-60), seems to be quite widespread and common in southern Chile south of Valdivia (Map), as well as in the adjacent Nahuel Huapi National Park, Argentina $\left(40^{\circ} 44^{\prime} \mathrm{S}, 71^{\circ} 39^{\prime} \mathrm{W}\right)$. The body is $26-28 \mathrm{~mm}$ long, $2.3-2.5$ and $3.5-3.8 \mathrm{~mm}$ wide on midbody proand metazonae, respectively $\left(\mathrm{O}^{7},+\right.$ ). Coloration is usually red-brown, with prominent, caudally mostly acute, laterally finely indentated paraterga; the postcollum metaterga are with low, but evident bosses arranged in four transverse rows; $O^{7}$ prefemora are not bulged laterally. 


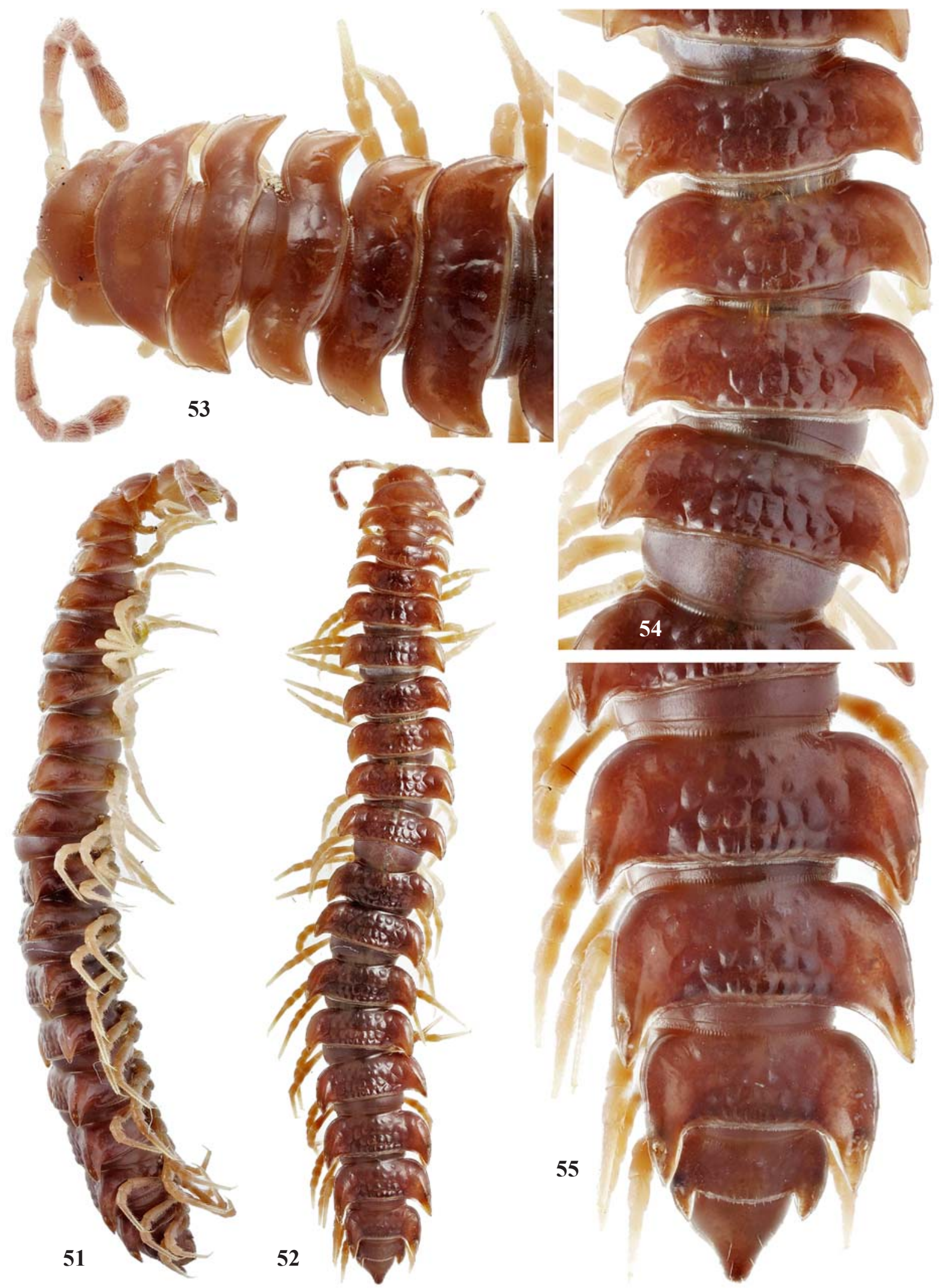

Figs 51-55. Monenchodesmus inermis Silvestri, 1903, $0^{7}$ from National Park Nahuelbuta. 51-52 - habitus, lateral and dorsal view, respectively; 53, 54-55 - anterior, middle and posterior parts of body, respectively, dorsal view. Pictures by K. Makarov, not taken to scale.

Рис. 51-55. Monenchodesmus inermis Silvestri, 1903, О7 из национального парка Nahuelbuta. 51-52 - обший вид, соответственно сбоку и сверху; 53, 54-55 - соответственно передняя, средняя и задняя части тела, сверху. Фотографии К. Макарова, без масштаба. 

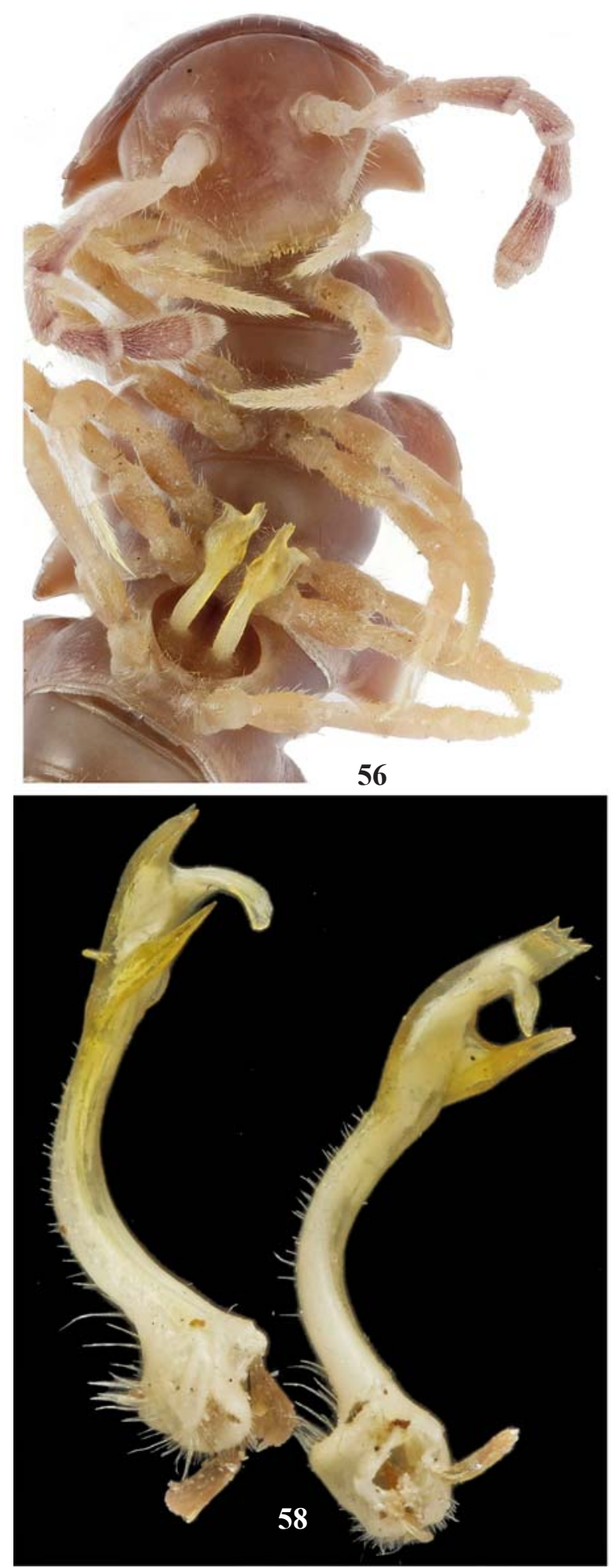
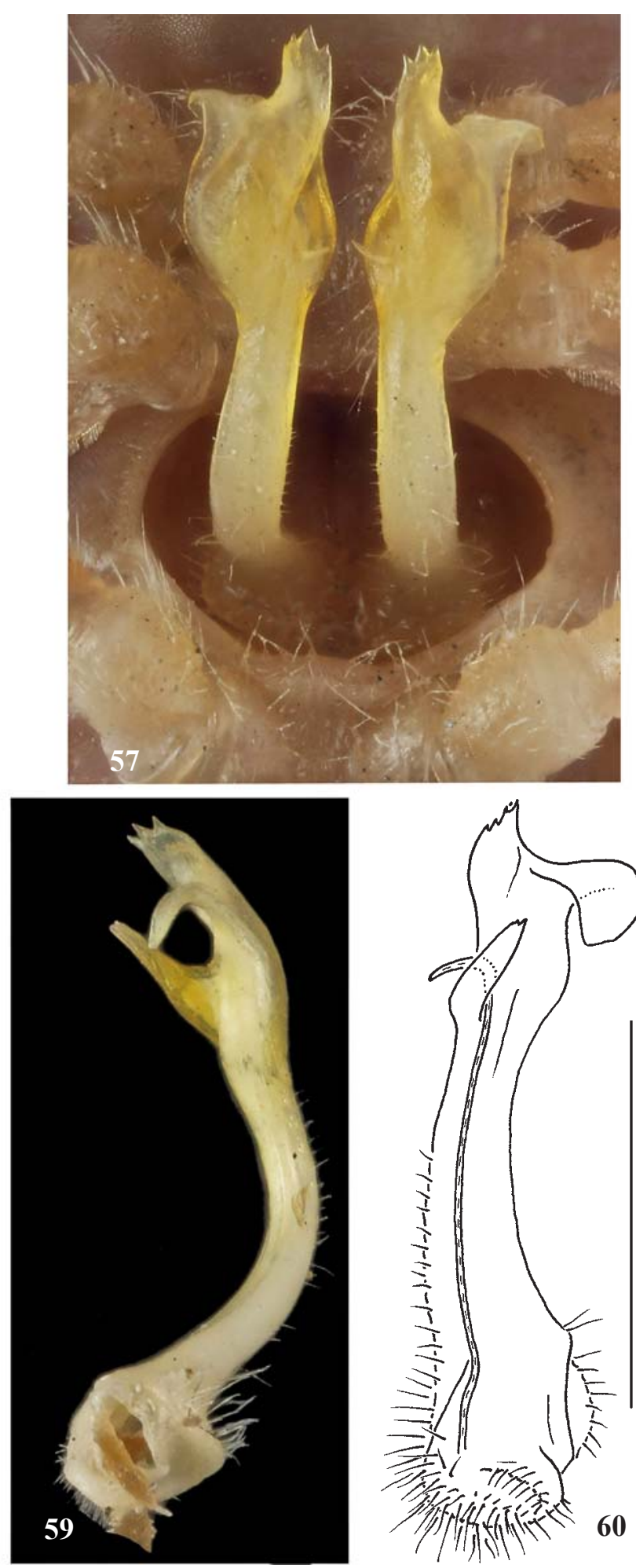

Figs 56-60. Monenchodesmus inermis Silvestri, 1903, $O^{7}$ from National Park Park Puehue (56-57) and $O^{7}$ from National Alerce Andino (58-60). 56 — anterior part of body, ventral view; 57 — gonopods in situ, ventrocaudal view; 58 — both gonopods, mesal and sublateral views, respectively; 59-60 - left gonopod, lateral and anterior views, respectively. Pictures by K. Makarov, not taken to scale (56-59). Scale bar: $1.0 \mathrm{~mm}(60)$.

Рис. 56-60. Monenchodesmus inermis Silvestri, 1903, О7 из национального парка Puehue (56-57) и О7 из национального парка Alerce Andino (58-60). 56 - передняя часть тела, снизу; 57 - гоноподы in situ, одновременно снизу и сзади; 58 - оба гопопода, соответственно изнутри и почти сбоку; 59-60 - левый гонопод, соответственно сбоку и спереди. Фотографии К. Макарова, без масштаба (56-59). Масштаб: 1,0 мм (60). 


\section{Tsagonus nahuelbutae Chamberlin, 1957}

Figs 61-68.

MATERIAL. $10^{7}, 1 \%$ (MNHN), Chile, National Park Puyehue, Anticura Sector, $40^{\circ} 40^{\prime} \mathrm{S}, 72^{\circ} 10^{\prime} \mathrm{W}$, ca $390 \mathrm{~m}$ a.s.l., Nothofagus forest, 14-20.01.2014, leg. D. Shcherbakov; 10 O $^{7} \mathrm{O}^{7}, 7$ 우, 5 juv., 1 fragm. (ZMUM 2413 ), National Park Nahuelbuta, Pehuenco, $37^{\circ} 50^{\prime} \mathrm{S}, 73^{\circ} 01^{\prime} \mathrm{W}$, ca $1120 \mathrm{~m}$ a.s.l., Nothofagus \& Araucaria forest, under logs \& stones, 22-26.01.2014; 1 O, 1 ㅇ (ZMUM p2414), National Park Alerce Andino, Sargazo Sector, 4130'S, $72^{\circ} 37^{\prime} \mathrm{W}$, ca $350 \mathrm{~m}$ a.s.l., Nothofagus \& Podocarpus forest, 511.01.2014, all leg. K. Eskov; 1 o', 1 + (ZMUM p2415), National Park Huerquehue, near Lake Tinquilco, $37^{\circ} 50^{\prime} \mathrm{S}, 73^{\circ} 01^{\prime} \mathrm{W}$, ca 1120 m a.s.1., Nothofagus forest, litter, 24-26.12.2013, leg. R. Rakitov.

REMARKS. The genus Tsagonus Chamberlin, 1957 has hitherto been considered to contain seven nominate species [Hoffman, 1980], all from Chile and the adjacent parts of Argentina. The above samples, partly strictly topotypic, definitely belong to $T$. nahuelbutae, as the new illustrations clearly document (Figs 61-68). Coloration of adults is rather uniform, ranging from marbled pinkish to pinkish (grey-) brown. The body is ca $25-27 \mathrm{~mm}$ in length, $2.5-2.7$ and $2.8-$
$3.0 \mathrm{~mm}$ in width on midbody pro- and metazonae, respectively $\left(\mathrm{O}^{\top},+\right)$. Paraterga are small, broadly rounded, narrowly rimmed only dorsally. Most of $\sigma^{7}$ prefemora are distinctly bulged laterally. The gonopods (Figs 65-68) are characterized by prominent, caudally or mediocaudally curved, lateral branches (lb), each bearing a mesal spinicle near the curvature point; the solenomeres (sl) are rather long, slender, suberect, paramedian branches bearing a paramedian pair of short, thin, contiguous spines caudally (c), being also flanked by similarly short, slightly curved, anterolateral prongs (a) [cf. Chamberlin, 1957; Demange \& Silva, 1976a].

Because the remaining congeners of $T$. nahuelbutae, i.e. T. muermo Chamberlin, 1957, T. osorno Chamberlin, 1957 (the type species), T. puconus Chamberlin, 1957, T. valdiviae Chamberlin, 1957, T. silvestrii (Demange \& Silva, 1976) and T. silvestrii solervicensi (Demange \& Silva, 1976), are all so similar to one another, their statuses require verification. Demange \& Silva [1976a] treated all these taxa as belonging to group A, or the silvestrii-group, of the genus Semnosoma Silvestri, 1903, also providing a key for their identification.

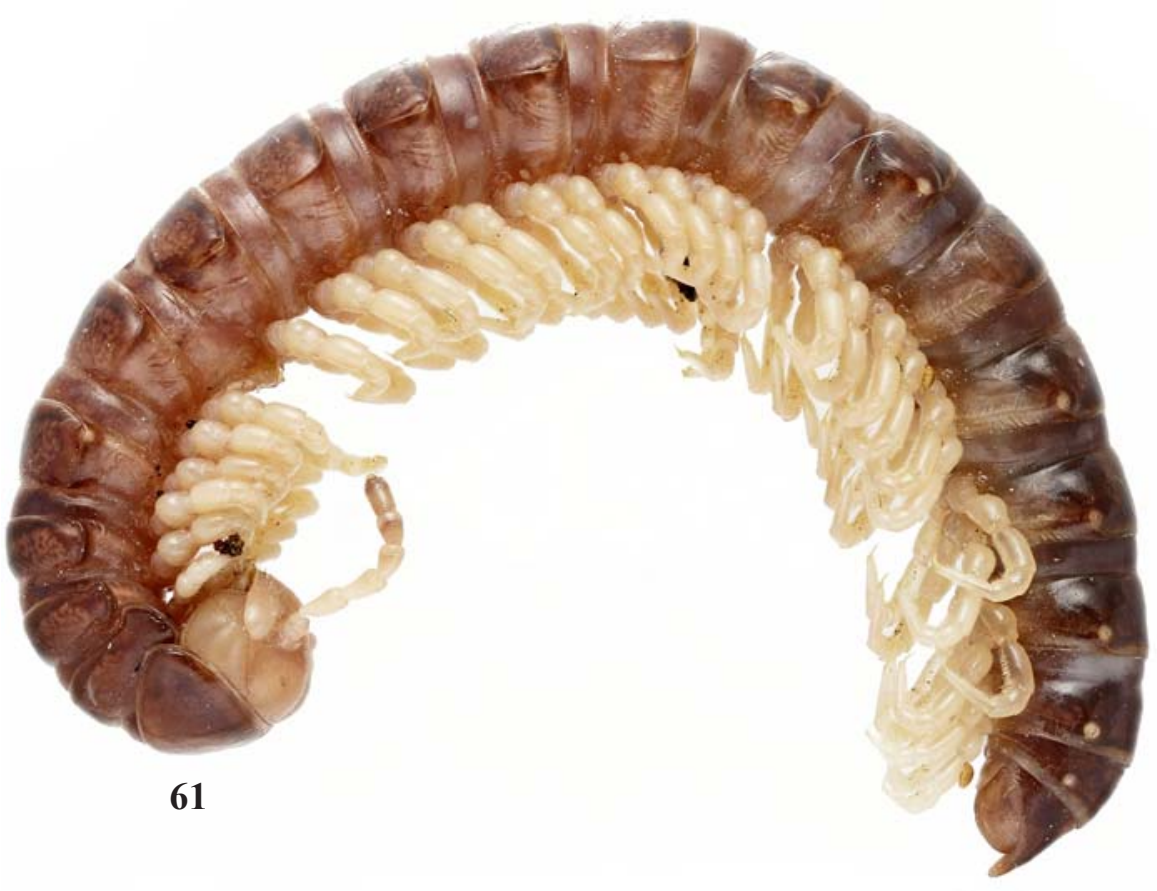

62

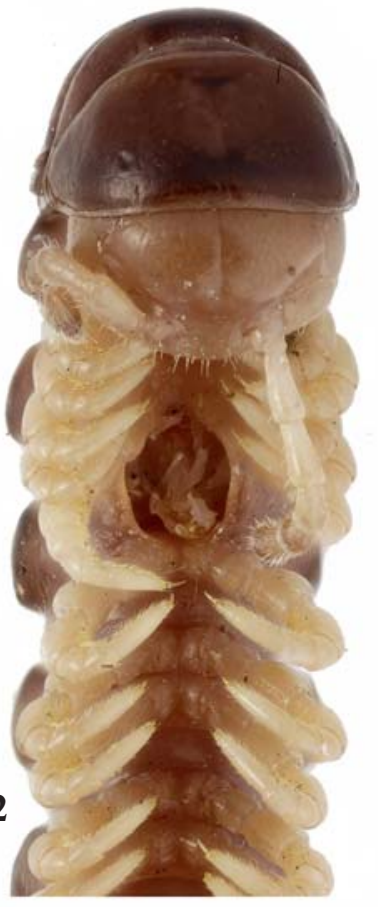

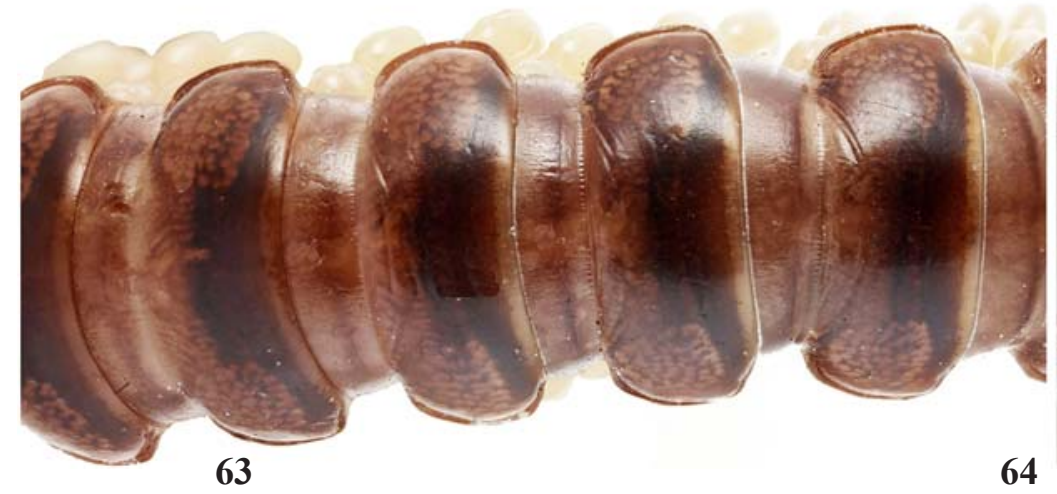

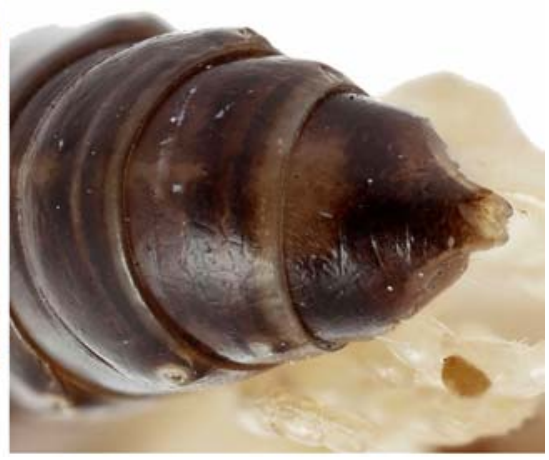

Figs 61-64. Tsagonus nahuelbutae Chamberlin, 1957, ơ from National Park Nahuelbuta. 61 - habitus, lateral view; 62-64 - anterior, middle and posterior parts of body, ventral, dorsal and dorsal views, respectively. Pictures by K. Makarov, not taken to scale.

Рис. 61-64. Tsagonus nahuelbutae Chamberlin, 1957, о7 из национального парка Nahuelbuta. 61 - общий вид, сбоку; 62-64 передняя, средняя и задняя части тела, соответственно снизу, сверху и сверху. Фотографии К. Макарова, без масштаба. 
However, variation in gonopod structure is generally so minor that Tsagonus seems to represent a nice model for future molecular studies, bar-coding in particular.

Demange [1963] reported "Anaulacodesmus" concolor (Gervais, 1847) from Nahuel Huapi (4044'S, 71 $39^{\circ} \mathrm{W}$ ), Argentina, apparently relying on Attems' [1898, 1940] (mis)identification. Later, based on a revision of the 9 holotype of Strongylosoma concolor Gervais, 1847, Demange \& Silva [1976a] found this species to be different from what Attems [1898, 1940] and Silvestri [1905] had identified as Anaulacodesmus concolor or Semnosoma concolor, respectively, and renamed the latter species as $S$. silvestrii Demange \& Silva, 1976. Hoffman [1980], following Chamberlin's [1957] assignment of "concolor" in the sense of Attems [1898, 1940] and Silvestri [1905], treated S. silvestrii within Tsagonus, resurrecting the latter genus from synonymy under Semnosoma and restricting it to some three species from
Chile. Here I follow Hoffman's [1980] classification, also adding a new Semnosoma.

In addition, Demange \& Silva [1976a] corrected Demange's [1963] earlier misidentification and referred the Nahuel Huapi sample to T. valdiviae Chamberlin, 1957, albeit still assigning it to "Anaulacodesmus".

\section{Semnosoma eskovi sp.n.}

Figs 69-78.

HOLOTYPE $0^{7}$ (ZMUM 2416 ), Chile, National Park Puyehue, Antillanca Sector, $40^{\circ} 46^{\prime} \mathrm{S}, 72^{\circ} 12^{\prime} \mathrm{W}$, ca $1060 \mathrm{~m}$ a.s.l., Nothofagus \& Podocarpus forest, moss, 16.01.2014, leg. K. Eskov.

PARATYPES. 1 subad. $\&$ (ZMUM $\rho 2417$ ), same data, together with holotype; $20^{\top} 0^{\top}, 1+$ (ZMUM $\rho 2418$ ), same locality, Anticura Sector, $40^{\circ} 40^{\prime} \mathrm{S}, 72^{\circ} 10^{\prime} \mathrm{W}$, ca $390 \mathrm{~m}$ a.s.l., Nothofagus forest, under logs, 14-20.01.2014, leg. K. Eskov.

NAME. Honours Kirill Y. Eskov, the main collector.
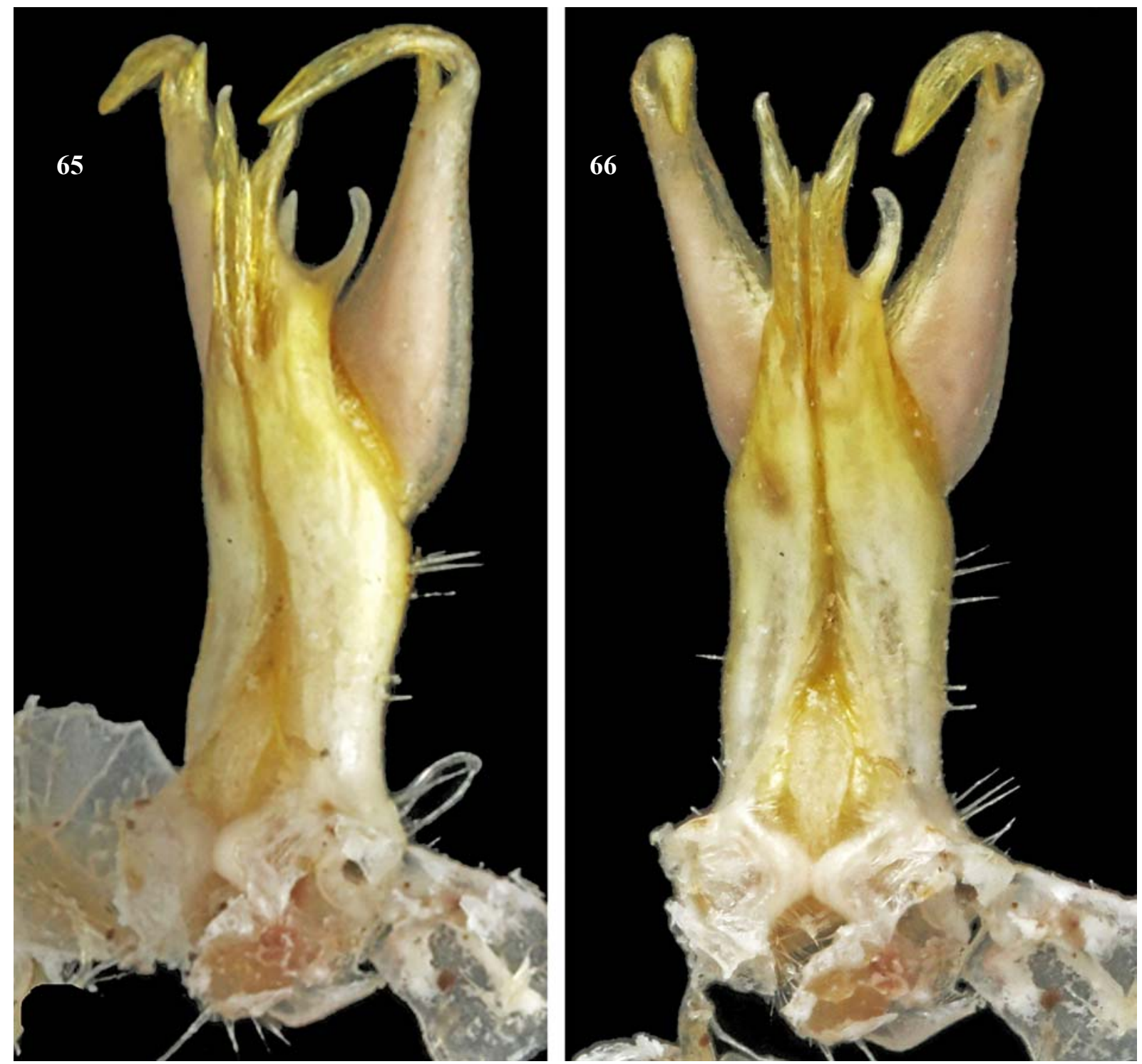

Figs 65-66. Gonopodial block of Tsagonus nahuelbutae Chamberlin, 1957, $\bigcirc^{7}$ from National Park Nahuelbuta, caudolateral and caudal views, respectively. Pictures by K. Makarov, not taken to scale.

Рис. 65-66. Гоноподиальный блок Tsagonus nahuelbutae Chamberlin, 1957, ơ из национального парка Nahuelbuta, coответственно одновременно сзади и сбоку, а также сзади. Фотографии К. Макарова, без масштаба. 

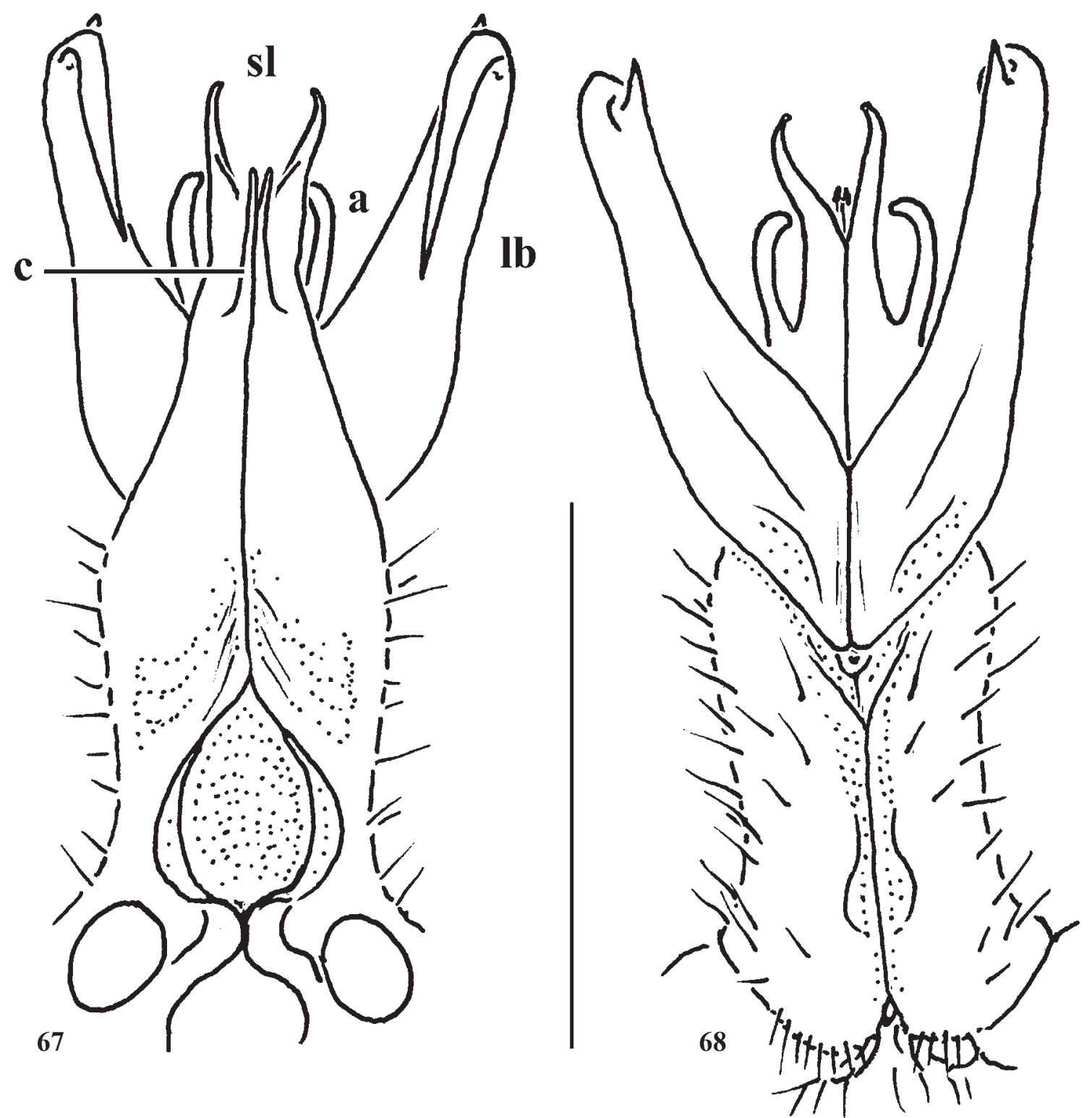

Figs 67-68. Gonopodial block of Tsagonus nahuelbutae Chamberlin, 1957, o from National Park Nahuelbuta, posterior and anterior views, respectively. Scale bar: $1.0 \mathrm{~mm}$. Designations in text.

Рис. 67-68. Гоноподиальный блок Tsagonus nahuelbutae Chamberlin, 1957, О7 из национального парка Nahuelbuta, соответственно сзади и спереди. Масштаб: 1,0 мм. Обозначения в тексте.

DIAGNOSIS. Differs from all three known congeners, S. concolor (Gervais, 1847) (the type-species, according to Hoffman [1980], = Chilorus ovallenus Chamberlin, 1957, the type species of Chilorus Chamberlin, 1957), S. permutatus Attems, 1940 (nom.n. pro Chiliosoma porteri Brölemann, 1916, nom.praeoccup.) and S. zapallar Chamberlin, 1957 , by the rather small, single, caudomedially curved solenomere (sl), coupled with the deeply split apicocaudal branch (cb1 and cb2).
DESCRIPTION. Length ca $14-16 \mathrm{~mm}$, width of midbody pro- and metazonae $1.4-1.6$ and $1.7-1.9 \mathrm{~mm}$, respectively $\left(\sigma^{\top},+\right)$. Holotype ca $15 \mathrm{~mm}$ long, 1.5 and $1.9 \mathrm{~mm}$ wide on midbody pro- and metazonae, respectively. General coloration in alcohol light marbled grey brown to grey-brown usually with a vague pattern of darker sides and a central, more or less triangular spot on metaterga (Figs 69-73); legs light grey to nearly pallid.

Body with 20 segments, slightly moniliform. In width, segment $2=3<$ head $=$ collum $=$ segment $5<6-16$; thereafter

Figs 69-73. Semnosoma eskovi sp.n., ơ paratype. 69 - habitus, lateral view; 70-73 — anterior, anterior, middle and posterior parts of body, dorsal, ventral, dorsal and dorsal views, respectively. Pictures by K. Makarov, not taken to scale.

Рис. 69-73. Semnosoma eskovi sp.n., паратип ○'. 69 - общий вид, сбоку; 70-73 - передняя, передняя, средняя и задняя части тела, соответственно сверху, снизу, сверху и сверху. Фотографии К. Макарова, без масштаба. 

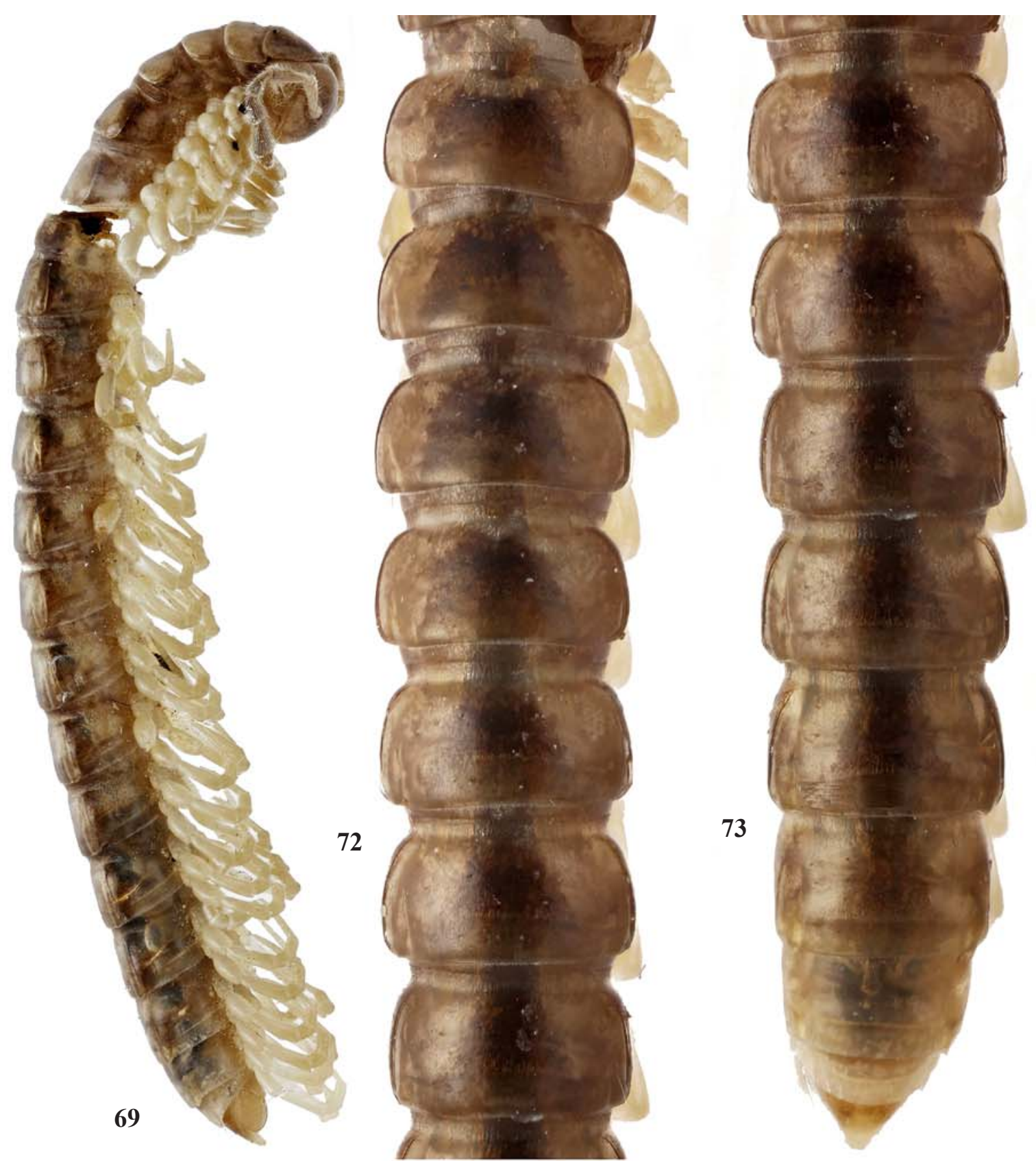

73
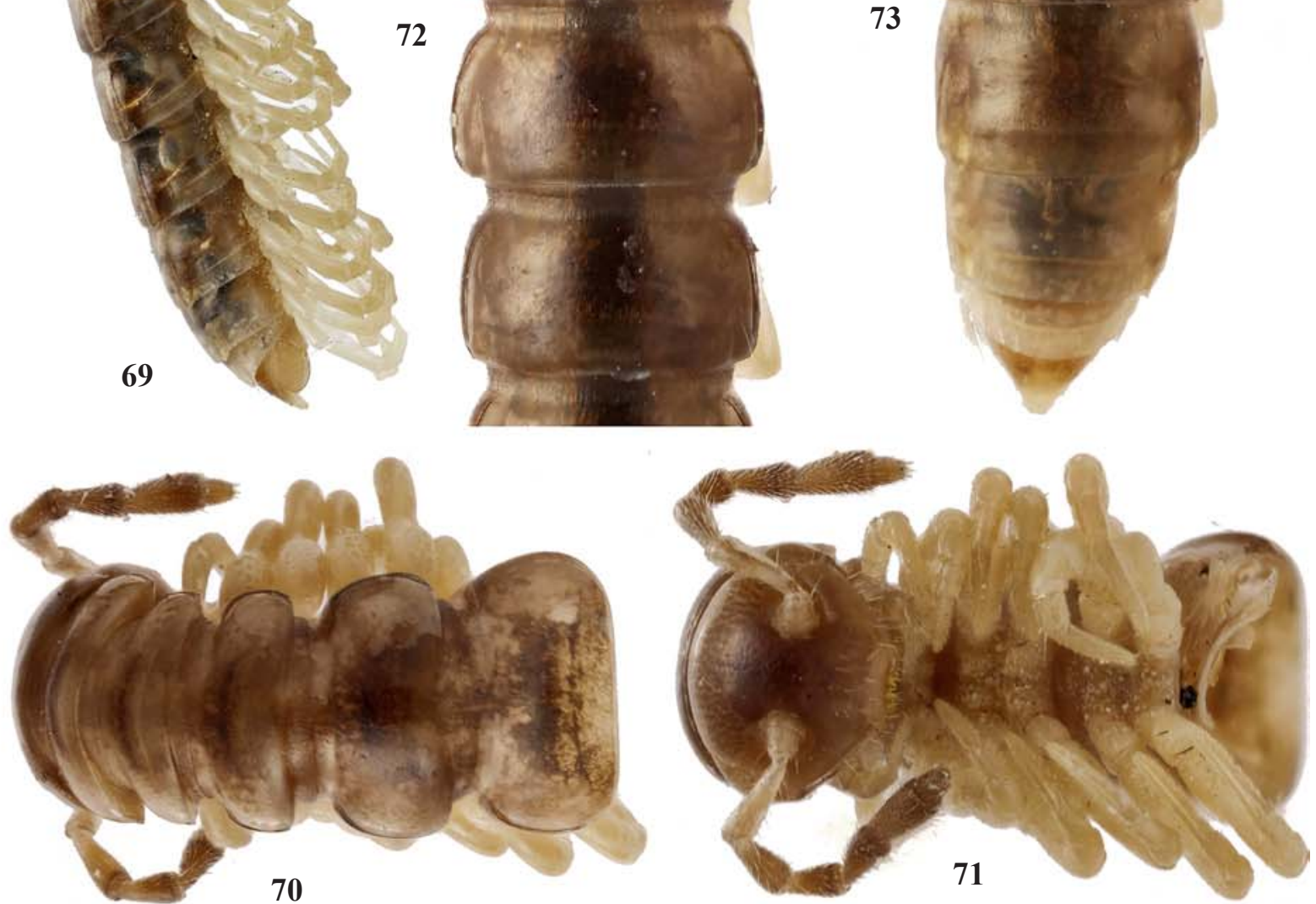

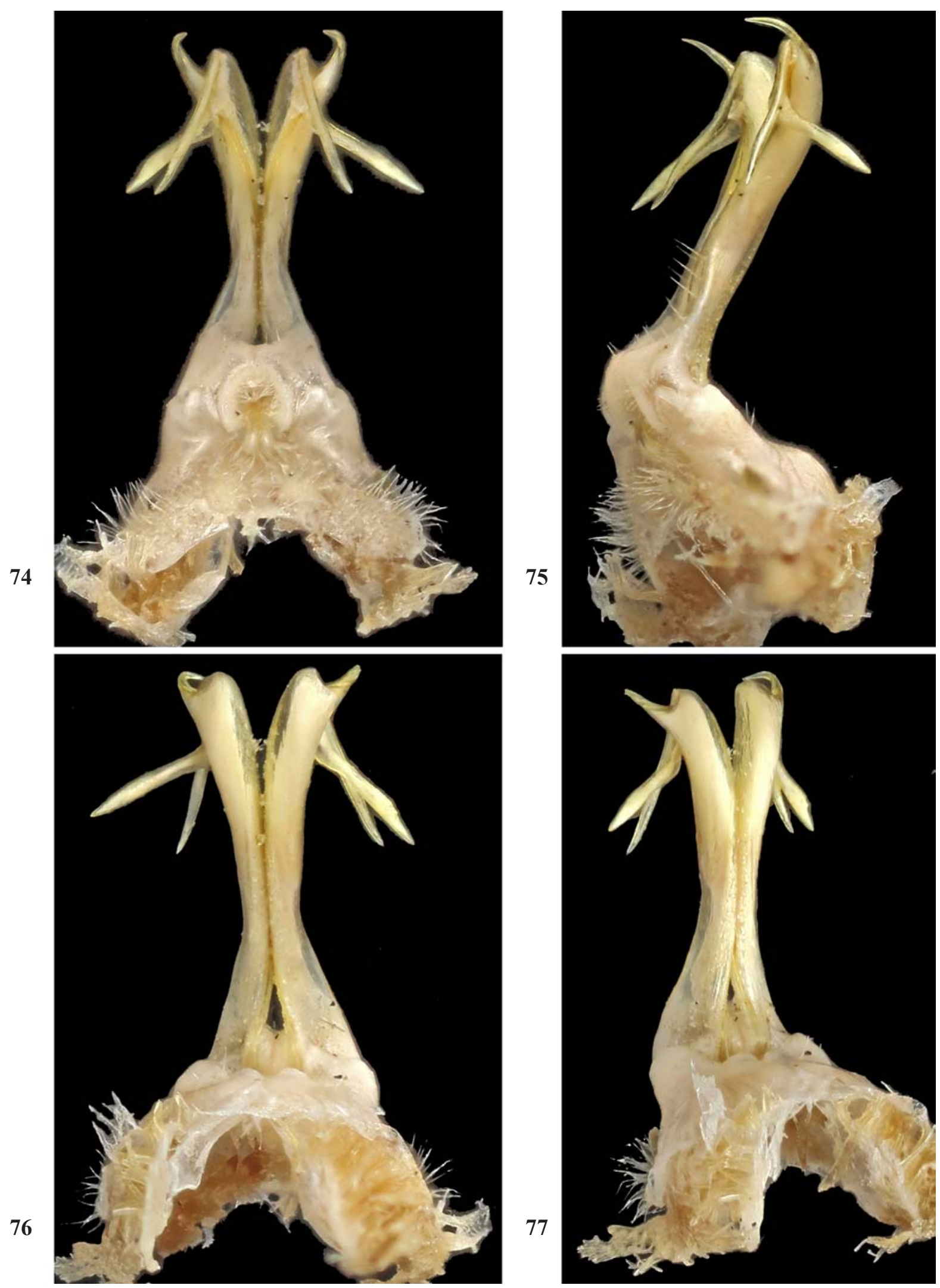

Figs 74-77. Gonopodial block of Semnosoma eskovi sp.n., O' paratype: 74-75 — posterior and lateral views, respectively; 76-77 — anterior and nearly anterior views, respectively. Pictures by K. Makarov, not taken to scale.

Рис. 74-75. Гоноподиальный блок Semnosoma eskovi sp.n., паратип О': 74-75 - соответственно сзади и сбоку: 76-77 соответственно спереди и почти спереди. Фотографии К. Макарова, без масштаба. 


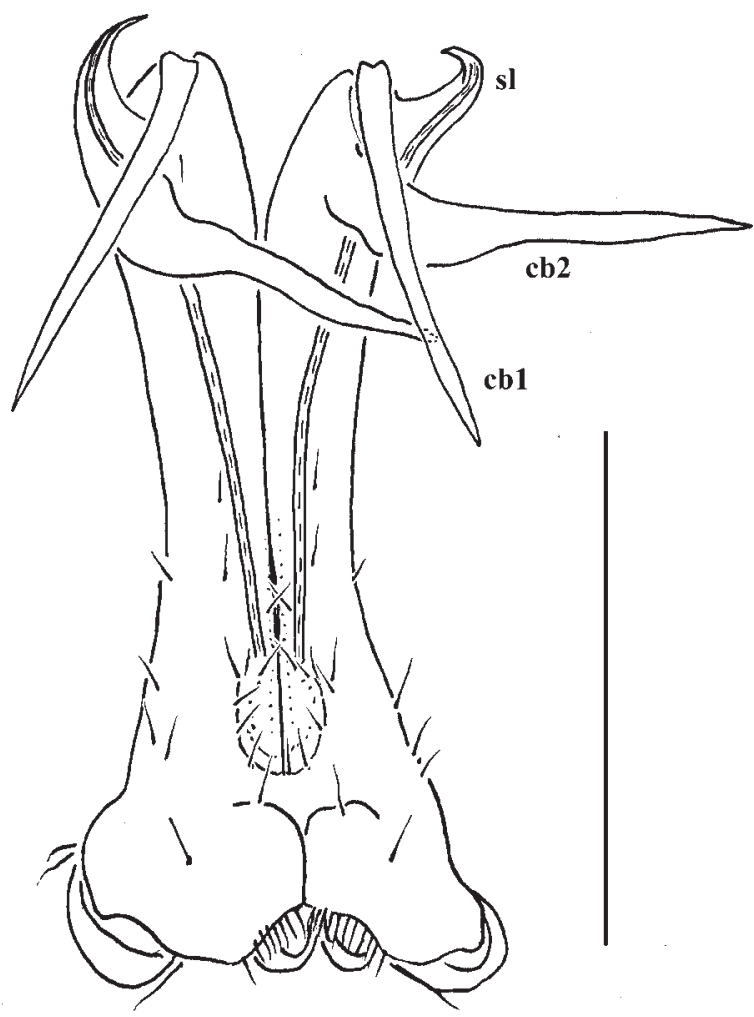

Fig. 78. Gonopodial block of Semnosoma eskovi sp.n., О7 holotype, nearly posterior view. Scale bar: $0.5 \mathrm{~mm}$. Designations in text.

Рис. 78. Гоноподиальный блок Semnosoma eskovi sp.n., голотип $\sigma^{7}$, почти сзади. Масштаб: 0,5 мм. Обозначения в тексте.

body gradually tapering. Clypeolabral region rather sparsely setose, vertigial region bare. Antennae long, extending back behind segment 3 when stretched dorsally, a little shorter in + than in $\sigma^{7}$, somewhat clavate; in length, antennomeres $2=3$ $=6>4=5>1 ; 5^{\text {th }}$ and $6^{\text {th }}$ each with a small distodorsal group of minute bacilliform sensilla. Paraterga very poorly developed (Figs 69-73), invariably broadly rounded, narrowly rimmed only dorsally, never produced behind tergal margin, set low, mostly lying at ca $1 / 3$ of midbody height. Pore formula normal $(5,7,9,10,13,15-19)$, ozopores dorsolateral, lying slightly in front of caudal corner. Body surface shining and mostly smooth throughout, texture microalveolate. Limbus microspiculate. Axial line, tergal setae and pleurosternal carinae wanting. Stricture dividing pro- and metazonae rather broad and shallow, very finely striolate dorsally and dorsolaterally. Epiproct long, subtruncate, subapical lateral papillae very small. Hypoproct subtrapeziform, caudal $1+1$ setae borne on small knobs and well separated.

Sternites without modifications, poorly setose; crossimpressions evident. Legs long, in $\sigma^{\top}$ obviously incrassate, ca 1.4-1.5 times as long as body height, prefemora 3-7 particularly strongly swollen laterally, increasingly poorly bulged thereafter; $O$ telopodites very densely setose ventrally, with abundant sphaerotrichomes, in $q$ slender, unmodified, only ca 1.1 times as long as body height.

Gonopods (Figs 74-78) with short, medially fused, basally densely setose coxites, the latter with curved, medially contiguous cannulae; telopodites contiguous medially, held subrectangular to coxae, suberect, each bearing a seminal groove on caudal face alone; prefemoral part sparsely setose, about as long as acropodite; the latter crowned by a lateral, unciform, inward curved solenomere (sl) and a distinct geniculation turning into a long, slender, caudal branch split into two spines (cb1 \& $\mathbf{c b 2})$ at its very base.

\section{Abatodesmus simplicior sp.n.} Figs 79-86.

HOLOTYPE OT (ZMUM 2 2419), Chile, National Park Nahuelbuta, Pehuenco, $37^{\circ} 50^{\prime} \mathrm{S}, 73^{\circ} 01^{\prime} \mathrm{W}$, ca $1120 \mathrm{~m}$ a.s.l., Nothofagus \& Araucaria forest, under logs \& stones, 22-26.01.2014, leg. K. Eskov.

PARATYPES: $3 \sigma^{7} \sigma^{7}$ (ZMUM 2420$), 1 \sigma^{7}$ (MNHN), same data, together with holotype.

NAME. To emphasize a gonopod conformation somewhat simpler than in other congeners.

DIAGNOSIS. Differs from both hitherto known congeners, A. chilensis Silvestri, 1903 (the type species), from Coipué ( $\left.35^{\circ} 15^{\prime} 0^{\prime \prime} \mathrm{S}, 72^{\circ} 4^{\prime} 0^{\prime \prime} \mathrm{W}\right)$, Constitución, Talca, central Chile, and A. velosoi Demange \& Silva, 1971, from Nahuelbuta, southern Chile, by the shape of the various outgrowths (sl, c, a and ib) of the gonopod tip [cf. Demange \& Silva, 1971b].

DESCRIPTION. Length ca 21-22 mm, width of midbody pro- and metazonae $1.8-1.9$ and $2.0-2.1 \mathrm{~mm}$, respectively $\left(\sigma^{7}\right)$. Holotype ca $21 \mathrm{~mm}$ long, 1.8 and $2.0 \mathrm{~mm}$ wide on proand metazonae, respectively. Coloration generally marbled pinkish brown to dark brown, legs yellowish (Figs 79-83).

All characters as in Semnosoma eskovi sp.n., except as follows.

Antennae short, extending back only behind collum $\left(O^{7}\right)$. Paraterga very poorly developed (Figs 79-83), broadly rounded, very narrowly rimmed only dorsally, never produced behind tergal margin. Surface below paraterga with a few arcuated striae. Stricture dividing pro- and metazonae thin, rather shallow, ribbed dorsally and dorsolaterally. Hypoproct roundly subtriangular, caudal $1+1$ setae borne on small knobs and rather poorly separated.

Legs short, obviously incrassate, ca 1.1-1.2 times as long as body height, prefemora mostly strongly swollen laterally, increasingly poorly bulged until posterior $1 / 3$ body.

Gonopods (Figs 84-86) especially complex; prefemoral (= setose) part of telopodites contiguous medially; acropodites somewhat longer and divergent, bearing seminal grooves on anterior face and divided distally into paramedian pairs of lateral solenomeres (sl), smaller digits (c), longer inner branches (ib) and caudal spines (a).

REMARKS. The genus Abatodesmus Silvestri, 1903 has been revised by Demange \& Silva [1971b] and is known to contain only two species [Hoffman, 1980], both from Chile and both showing especially complex gonopod tips. The new species is sympatric with $A$. velosoi (see Map), but differs very clearly in a somewhat less complex gonopod structure.

\section{Anaulacodesmus angolus Chamberlin, 1957} Figs 87-95.

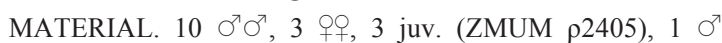
(MNHN), Chile, National Park Nahuelbuta, Pehuenco, $37^{\circ} 50^{\prime} \mathrm{S}$, $73^{\circ} 01^{\prime} \mathrm{W}$, ca $1120 \mathrm{~m}$ a.s.1., low Nothofagus forest with gramineous tussocks, litter, 26.01.2014, leg. K. Eskov.

REMARKS. The genus Anaulacodesmus Attems, 1898 is certainly the largest and most widespread among the Dalodesmidae of Chile and Argentina, counting 16 species [Hoffman, 1980]. The gonopods of Anaulacodesmus are quite uniform, each gonopod normally being characteristically tri- 

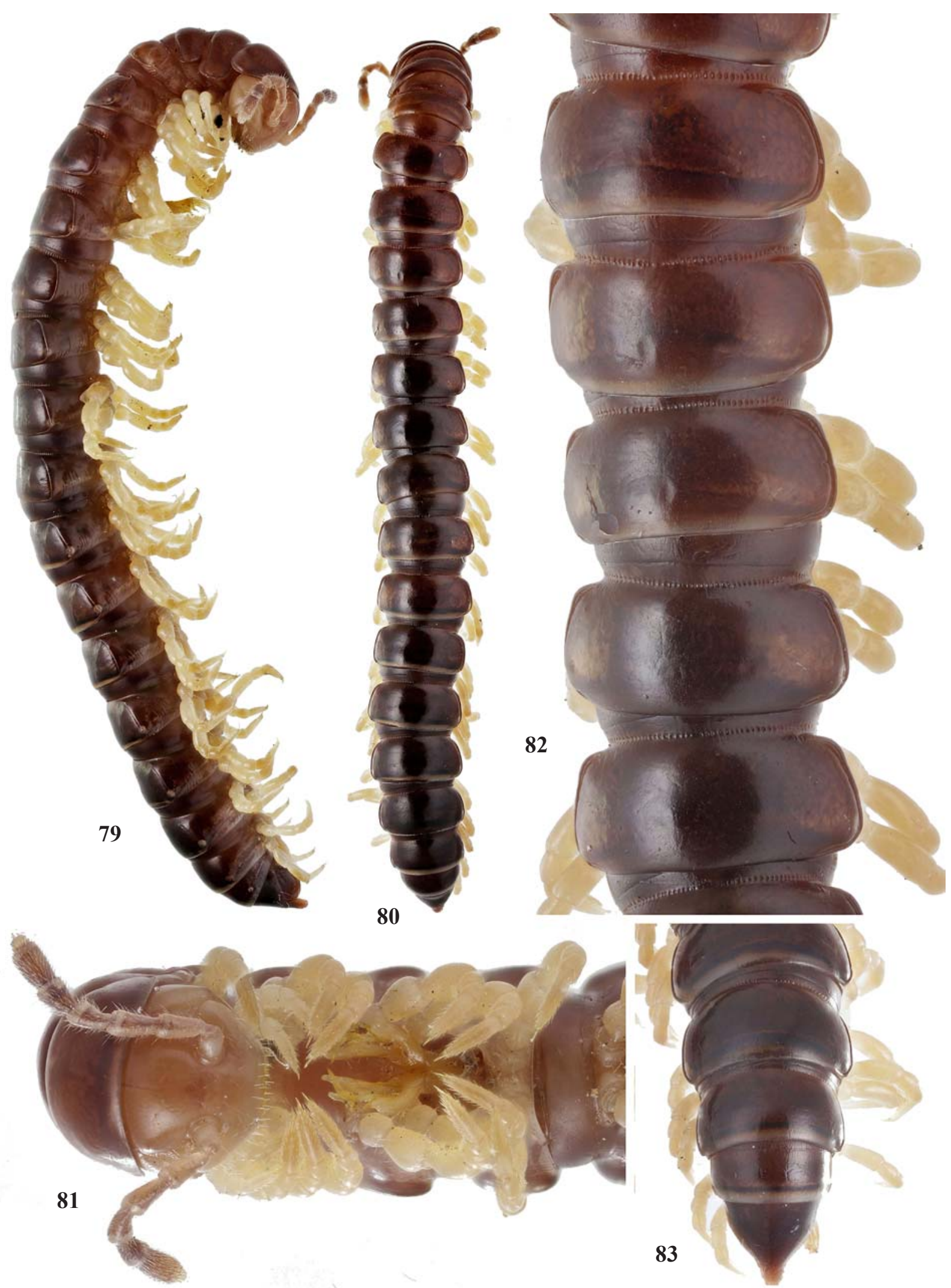

Figs 79-83. Abatodesmus simplicior sp.n., O' paratype. 79-80 — habitus, lateral and dorsal views, respectively; 81-83 — anterior, middle and posterior parts of body, ventral, dorsal and dorsal views, respectively. Pictures by K. Makarov, not taken to scale.

Рис. 79-83. Abatodesmus simplicior sp.n., паратип O'. 79-80 - общий вид, соответственно сбоку и сверху; 81-83-передняя, средняя и задняя части тела, соответственно снизу, сверху и сверху. Фотографии К. Макарова, без масштаба. 

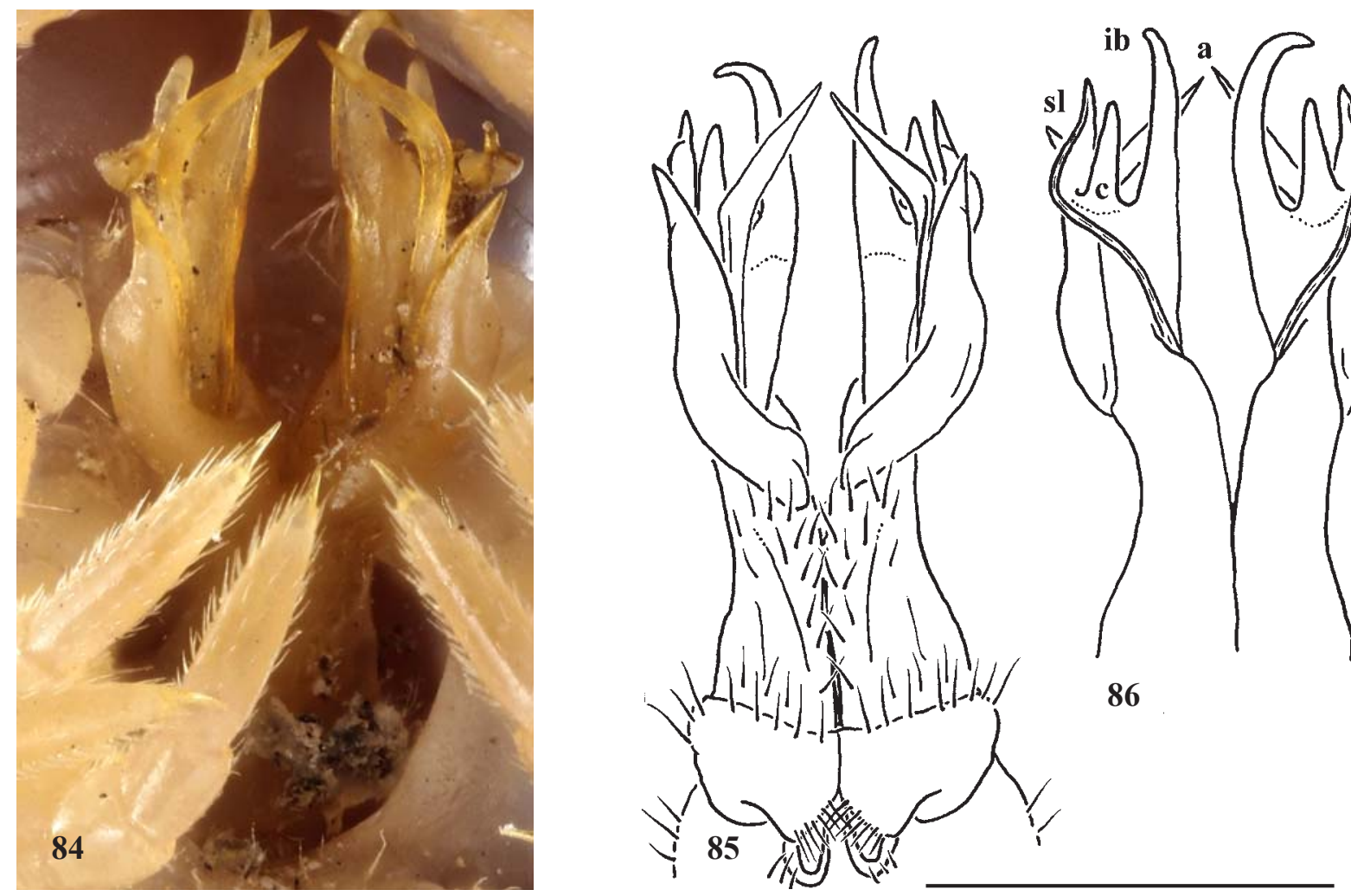

Figs 84-86. Gonopodial block of Abatodesmus simplicior sp.n., O' paratypes, posterior, posterior and anterior views, respectively. Picture by K. Makarov, not taken to scale (84); scale bar: $1.0 \mathrm{~mm}(85-86)$. Designations in text.

Рис. 84-86. Гоноподиальный блок Abatodesmus simplicior sp.n., паратипы Оㅇ', соответственно сзади, сзади и спереди. Фотография К. Макарова, без масштаба (84); масштаб: 1,0 мм (85-86). Обозначения в тексте.
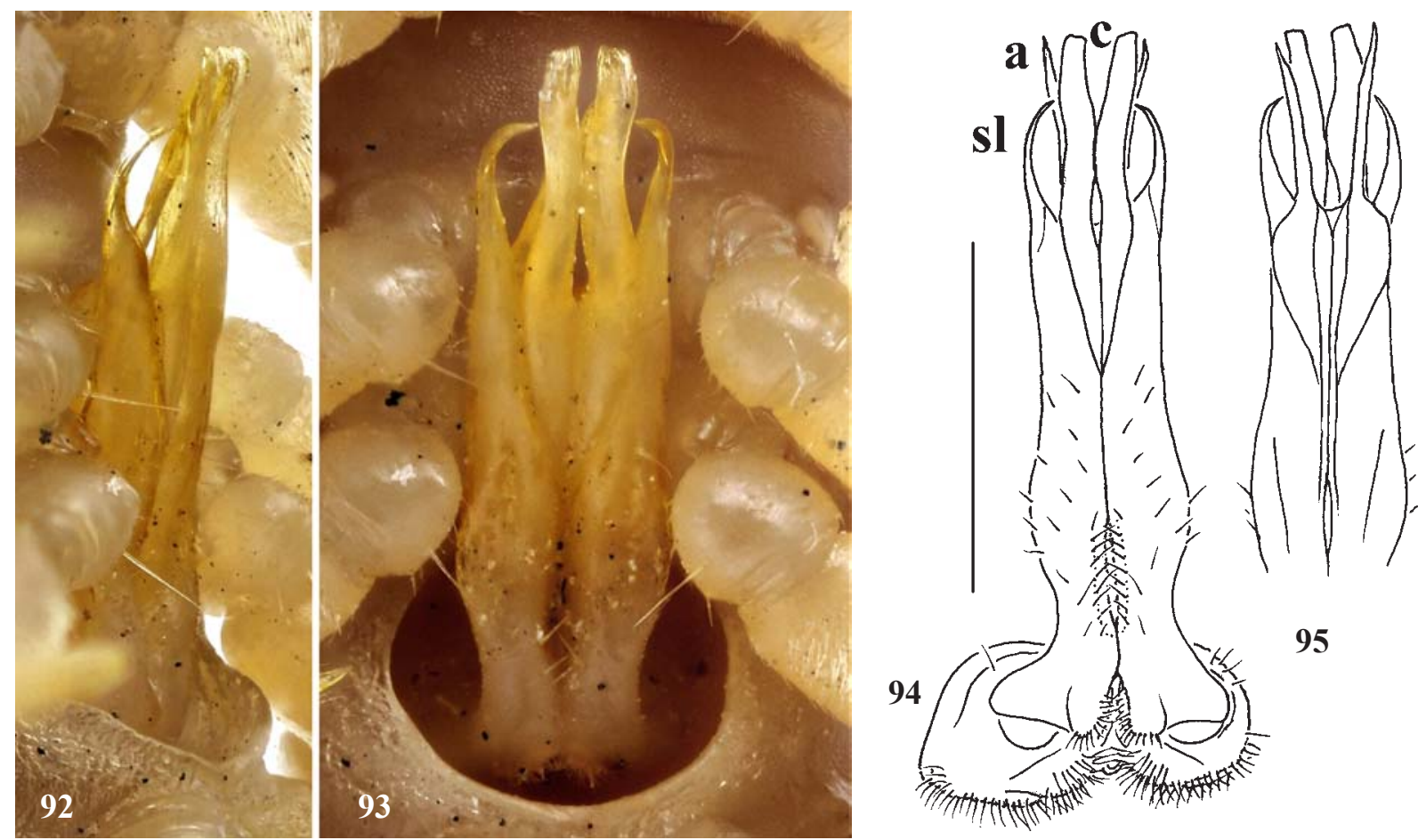

Figs 92-95. Gonopodial block of Anaulacodesmus angolus Chamberlin, 1957, $0^{7} 0^{\top}$, lateral, posterior, posterior and anterior views, respectively. Pictures by K. Makarov, not taken to scale (92-93); scale bar: $1.0 \mathrm{~mm}$ (94-95). Designations in text.

Рис. 92-95. Гоноподиальный блок Anaulacodesmus angolus Chamberlin, 1957, о7 о7, соответственно сбоку, сзади, сзади и спереди. Фотографии К. Макарова, без масштаба (92-93); масштаб: 1,0 мм (94-95). Обозначения в тексте. 


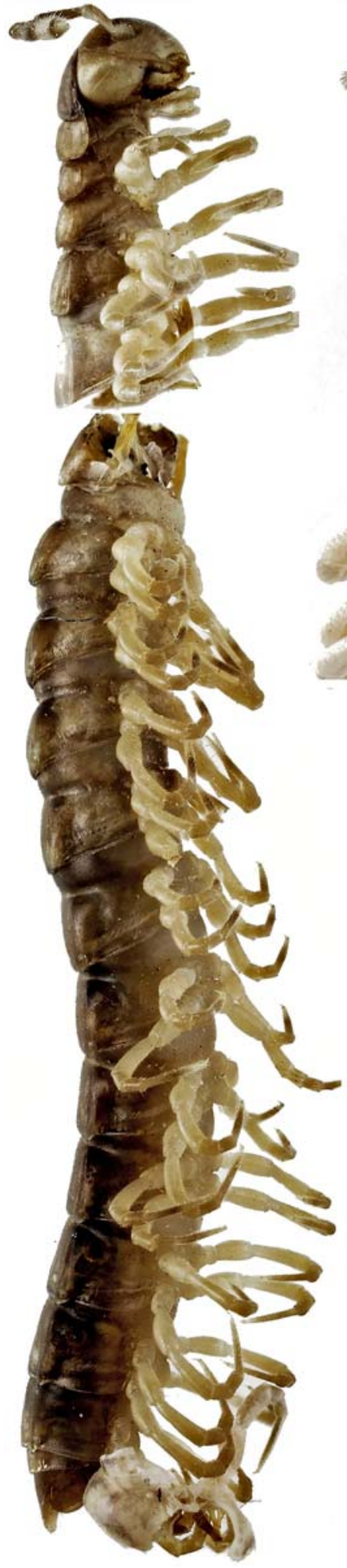

87

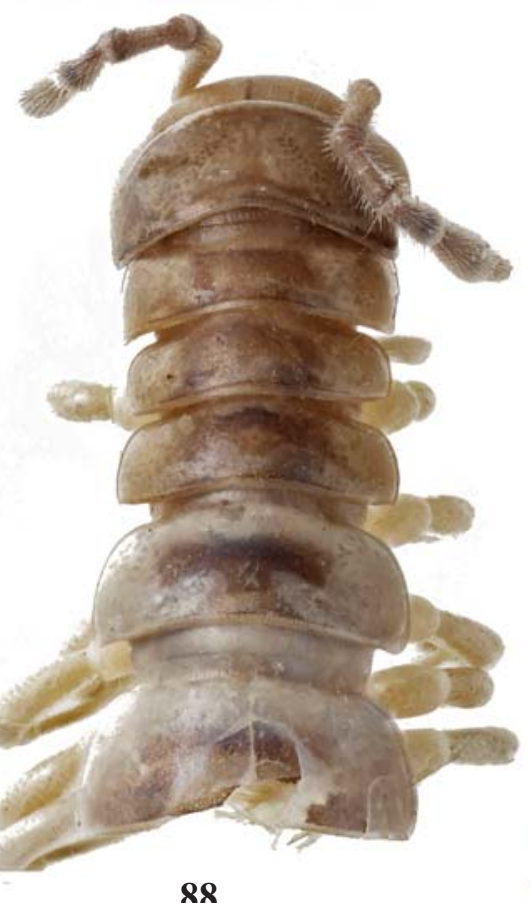

88
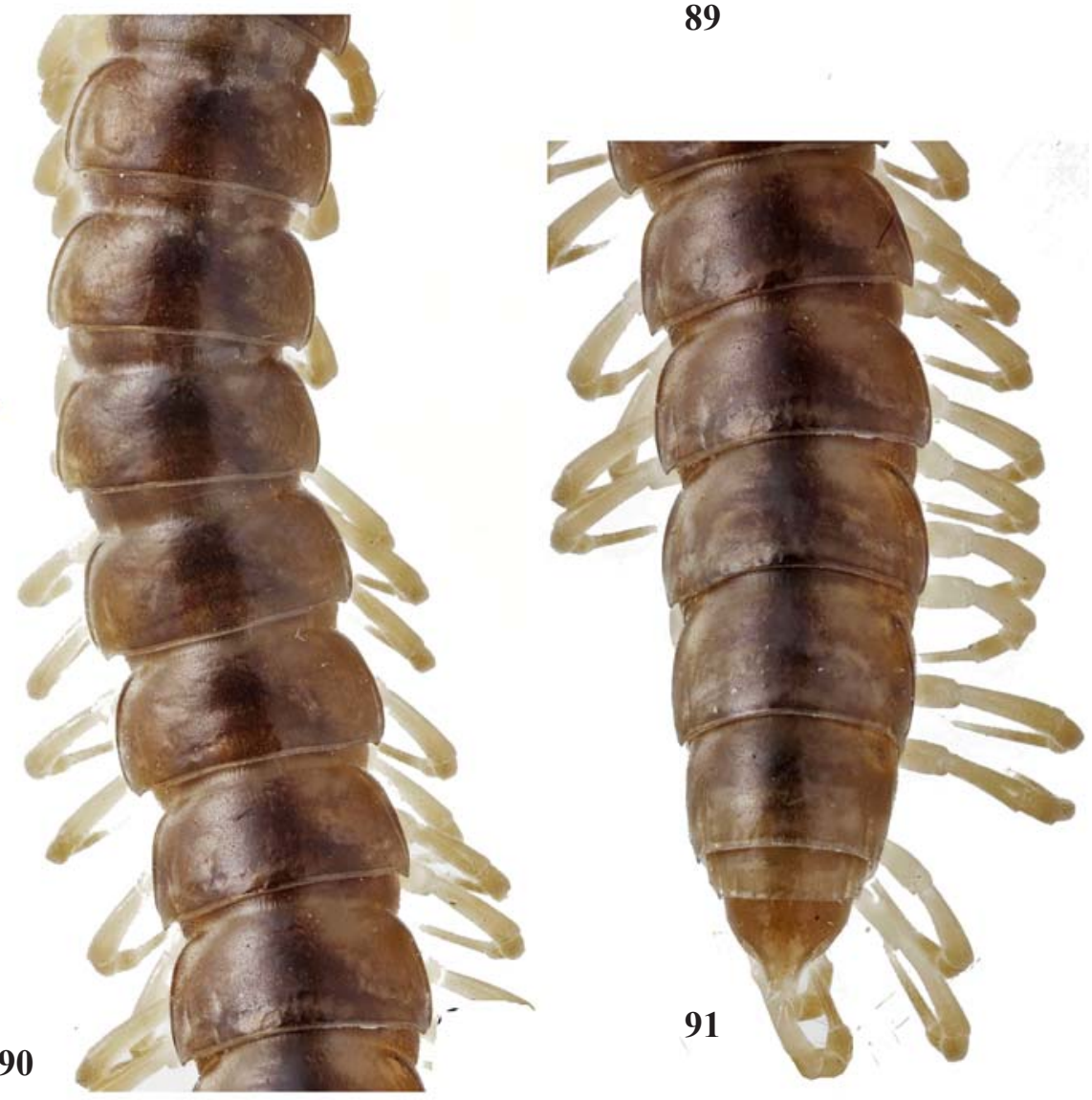

Figs 87-91. Anaulacodesmus angolus Chamberlin, 1957, O’. 87 — habitus, lateral view; 88-91 — anterior, anterior, middle and posterior parts of body, dorsal, ventral, dorsal and dorsal views, respectively. Pictures by K. Makarov, not taken to scale.

Рис. 87-91. Anaulacodesmus angolus Chamberlin, 1957, О7. 87 - общий вид, сбоку; 88-91-передняя, передняя, средняя и задняя части тела, соответственно сверху, снизу, сверху и сверху. Фотографии К. Макарова, без масштаба. 
fid, showing a lateral, usually somewhat curved and helicoid solenomere (sl), as well as paramedian caudal (c) and anterior (a) branches. Their shapes and relative proportions are deemed to be species-characteristic, although intraspecific variations are also observed.

The above samples unquestionably represent $A$. angolus, as described and depicted by Chamberlin [1957]. Moreover, they are strict topotypes (Map). The new illustrations (Figs 8795) are provided to document the identity of the new material. The body is $17-19 \mathrm{~mm}$ long, $1.8-1.9$ and $2.1-2.2 \mathrm{~mm}$ wide on midbody pro- and metazonae, respectively. Coloration light grey-brown to grey-brown, often with an indistinct pattern of central darker spots on metaterga. Paraterga are small, narrowly rimmed only dorsally, in rear body half small caudal spinicles. $\sigma^{7}$ prefemora 3-7 are especially distinctly bulged laterally, increasingly poorly so towards the rear body half. The gonopods show a pair of lateral, slender and rather long solenomeres (sl), both curved mesad, and two paramedian pairs of considerably higher branches, the caudal pair (c) being flattened/thicker and subtruncate, as opposed to a similarly high anterior pair of spiniform branches (a).

\section{Anaulacodesmus lacustris Schubart, 1954} Figs 96-101.

MATERIAL. $5 \sigma^{\top} \sigma^{\top}, 1$ \% (ZMUM $\rho 2421, \rho 2431$ ), Argentina, Villa la Angostura, National Park Arrayanes, $40^{\circ} 50^{\prime} \mathrm{S}, 71^{\circ} 37^{\prime} \mathrm{W}$, ca $800 \mathrm{~m}$ a.s.1., Luma \& Nothofagus forest, under logs \& stones, 23.12.2013; $7 \sigma^{7} \sigma^{7}, 12$ 우, 2 juv. (ZMUM 02422 ), Villa la Angostura, $40^{\circ} 472 \mathrm{~S}, 71^{\circ} 402 \mathrm{~W}$, wet Carex meadow, litter, 26.12.2013, all leg. K. Eskov; 1 ơ, 1 \%, 1 subad. $\sigma^{\top}$ (ZMUM $\rho 2423$ ), Chile, National Park Huerquehue, near Lake Tinquilco, $39^{\circ} 10^{\prime} \mathrm{S}, 71^{\circ} 44^{\prime} \mathrm{W}$, ca $780 \mathrm{~m}$ a.s.1., 20-26.12.2013, leg. D. Shcherbakov; $1 \mathrm{O}^{7}, 2$ 우, 1 juv., (ZMUM 2457 ), National Park Puyehue, Anticura Sector, $40^{\circ} 40^{\circ} \mathrm{S}, 72^{\circ} 10^{\circ} \mathrm{W}$, ca $390 \mathrm{~m}$ a.s.l., Nothofagus forest, under logs, 14-20.01.2014; $2 \mathrm{O}^{7} \mathrm{O}^{7}$ (MNHN), National Park Puyehue, Antillanca Sector, $40^{\circ} 46^{\prime} \mathrm{S}, 72^{\circ} 12^{\prime} \mathrm{W}$, ca $1060 \mathrm{~m}$ a.s.1., wet Juncus \& Carex meadow, litter, 16.01.2014; $1 \mathrm{O}^{7}$ (ZMUM $\left.\rho 2425\right)$, same locality, Anticura Sector, Nothofagus forest, under logs, 12-20.01.2014; all leg. K. Eskov.

REMARKS. This species has hitherto been known from some two localities in the Andes of Argentina [Schubart, 1954; Demange, 1963], i.e. the Nahuel Huapi (4044'S, $\left.71^{\circ} 39^{\prime} \mathrm{W}\right)$ and Lanín $\left(39^{\circ} 383 \mathrm{~S}, 71^{\circ} 302 \mathrm{~W}\right)$ national parks. The above samples document it from the adjacent parts of Chile as well, thus providing the first Chilean records (Map). The new illustrations (Figs 96-101) are given to document the identity of the new material. The body is 17 $18 \mathrm{~mm}$ long, 1.6-1.8 and 1.8-2.0 mm wide on pro- and metazonae, respectively $\left(O^{7},+\right)$. Coloration is generally pale grey to dark grey-brown, the pattern is often vague central triangular darker spots visible on metaterga. $\sigma^{7}$ prefemora 3-7 are especially distinctly bulged laterally, thereafter increasingly poorly so until about caudal $1 / 2-1 / 3$ body. The solenomeres (sl) are unusually small and rod-shaped, whereas the caudal (c) and anterior (a) branches are subequal in form and height.

\section{Anaulacodesmus levissimus Attems, 1898} Figs 102-118.

MATERIAL. $3 \sigma^{7} \sigma^{7}, 1$ ㅇ, 4 juv., 1 fragm. (ZMUM $\rho 2425-$ 2427), Chile, National Park Nahuelbuta, Pehuenco, $37^{\circ} 50^{\prime}$ S, $73^{\circ} 01^{\prime} \mathrm{W}$, ca $1120 \mathrm{~m}$ a.s.l., low Nothofagus forest with gramineous tussocks, litter, 26.01.2014; $1 \mathrm{O}^{\mathrm{T}}$ (MNHN), same locality, Nothofagus \& Araucaria forest, under logs \& stones, 22-26.01.2014, all leg. K. Eskov; $10^{7}, 5$ juv. (ZMUM $\rho 2428$ ), Chiloe Island, National Park Chiloe, $42^{\circ} 072 \mathrm{~S}, 74^{\circ} 012 \mathrm{~W}$, matorral, fern litter, 28.12.2013, leg. D. Takiya; $1 \sigma^{7}$ (ZMUM 02429$)$, Chiloe Island, Senda Darwin Biological Station (ca $15 \mathrm{~km}$ E of Ancud), $41^{\circ} 53^{\prime} \mathrm{S}, 73^{\circ} 40^{\prime} \mathrm{W}, 25 \mathrm{~m}$ a.s.l., wet gramineous meadow, litter, 2.01.2014; 1 o (ZMUM p2430), National Park Puyehue, Anticura Sector, $40^{\circ} 40^{\prime} \mathrm{S}, 72^{\circ} 10^{\prime} \mathrm{W}$, ca $390 \mathrm{~m}$ a.s.1., Nothofagus forest, under logs, 14-20.01.2014, all leg. K. Eskov.

REMARKS. This seems to be the most polymorphous species of Anaulacodesmus, with several morphs long delimited, mainly based on gonopod structure [e.g. Demange \& Silva, 1976b]. The new samples seem to represent a few morphs as well. Thus, adults from Nahuelbuta (Figs 102108) are 16-19 mm long, 1.7-1.9 and 2.0-2.4 mm wide on midbody pro- and metazonae, respectively; coloration is marbled grey-brown to dark brown, usually with a distinct pattern of darker central spots on metaterga; legs lighter, grey to yellowish; paraterga are poorly developed, very narrowly rimmed laterally, faintly produced behind tergal margin and dentiform only in segments 17-19; metaterga on each side above paraterga with a rather deep sublateral sulcus which is increasingly deep caudad and usually abbreviated/obliterated in anterior $1 / 2-2 / 3$; areation is normally strongly obliterated, better visible only in several caudal segments and above paraterga in 1-3 transverse caudal rows; sides below paraterga are typically with several arcuated striae; $\sigma^{7}$ prefemora $3-$ 7 are especially strongly bulged laterally, thereafter increasingly poorly so until legs of caudal $1 / 2-1 / 3$ body; legs are clearly incrassate, beset with ventral sphaerotrichomes and $1.4-1.5$ times as long as body height in $\sigma^{7}$, versus slender, unmodified and only 1.1-1.2 times as long as body height in + (Figs 102-105); gonopods (Figs 106-108) are with very slender, spiniform, anterior (a) and caudal (c) paramedian branches flanked by strong, clearly divergent solenomeres (sl). In the samples from Chiloe and Puyehue (Figs 109-118), most paraterga are dentiform caudally and slightly produced behind the rear tergal margin, whereas the solenomeres (sl) are rather convergent, also being much lower than both pairs of paramedical branches (a and $\mathbf{c}$ ).

It seems most advisable to apply bar-coding to check if $A$. levissimus is indeed a single species. In general, the taxonomy of Anaulacodesmus is still quite confused, remaining much to desire [cf. Attems, 1940; Chamberlin, 1957; Demange \& Silva, 1976b].

\section{Anaulacodesmus bifidus sp.n.}

Figs 119-127.

HOLOTYPE $0^{7}$ (ZMUM 2 2432), Chile, National Park Alerce Andino, Sargazo Sector, $41^{\circ} 30^{\prime} \mathrm{S}, 7^{\circ} 37^{\prime} \mathrm{W}$, ca $350 \mathrm{~m}$ a.s.1., Nothofagus \& Podocarpus forest, under logs, 5-11.01.2014, leg. K. Eskov.

PARATYPE: $1 \sigma^{\top}$ (ZMUM 22433$)$, National Park Puyehue, Anticura Sector, $40^{\circ} 40^{\prime} \mathrm{S}, 72^{\circ} 10^{\prime} \mathrm{W}$, ca $390 \mathrm{~m}$ a.s.l., Nothofagus forest, under logs, 14-20.01.2014, leg. K. Eskov.

NAME. To emphasize the bifid gonopod tip.

DIAGNOSIS. Differs clearly from all congeners by a bifid, not trifid, gonopod tip.

DESCRIPTION. Length ca $16-17 \mathrm{~mm}$, width of midbody pro- and metazonae 1.3 and 1.7 ( $\sigma^{7}$ paratype) or 1.5 and $1.8 \mathrm{~mm}\left(\mathrm{O}^{7}\right.$ holotype), respectively. General coloration in alcohol marbled grey brown with a vague pattern of darker sides and a central, more or less triangular spot on metaterga (Figs 119-123); legs light grey.

Body with 20 segments, slightly moniliform. In width, head $=$ segment $2=3<$ collum $=4<$ segment $5-16$; thereafter body gradually tapering. Clypeolabral region sparsely setose, vertigial region bare. Antennae very long and slender, extending back behind segment 3 or 4 when stretched dorsally; in length, antennomeres $2=3>6>4=5>1 ; 5^{\text {th }}$ and $6^{\text {th }}$ each with a small distodorsal group of minute bacilliform sensilla. Paraterga very poorly developed (Figs 119-123), mostly 


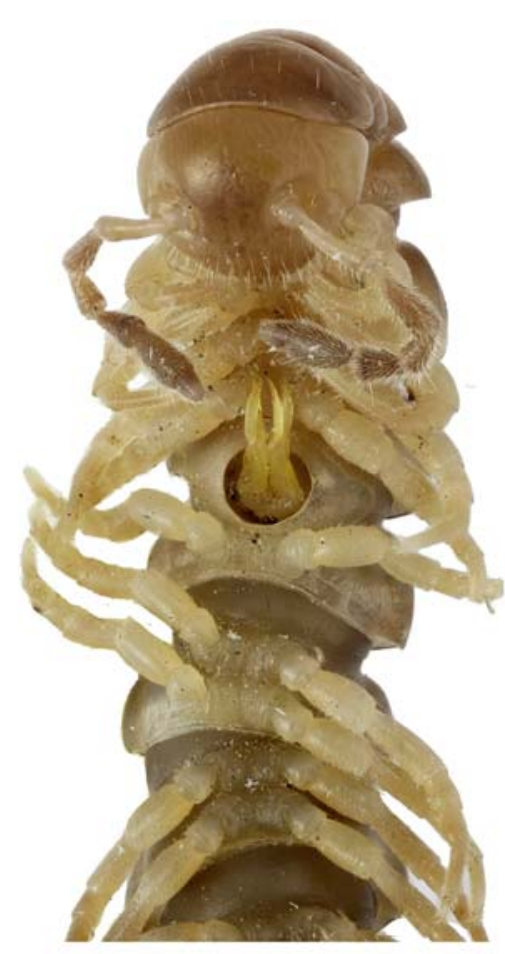

96

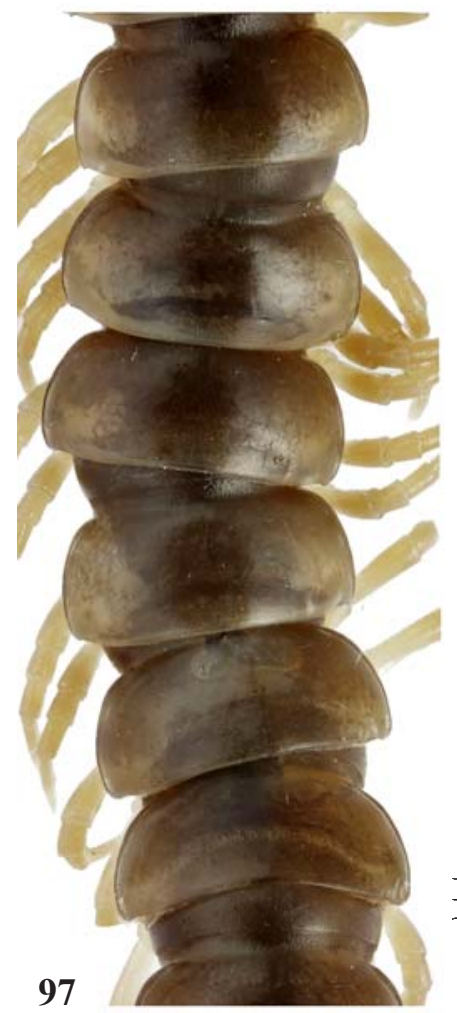

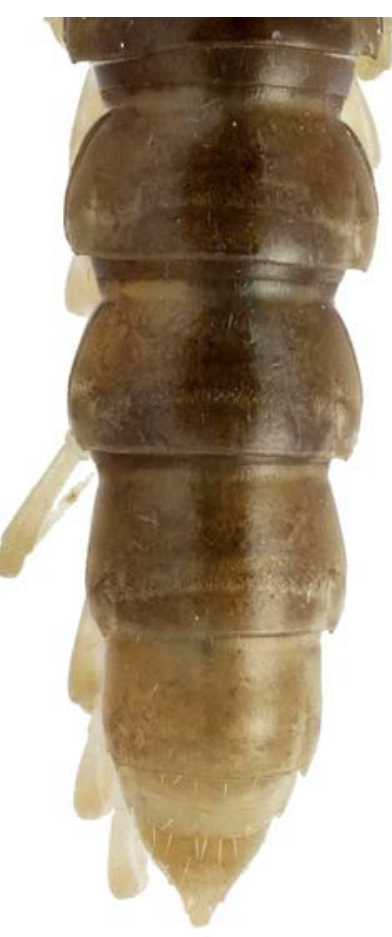

98

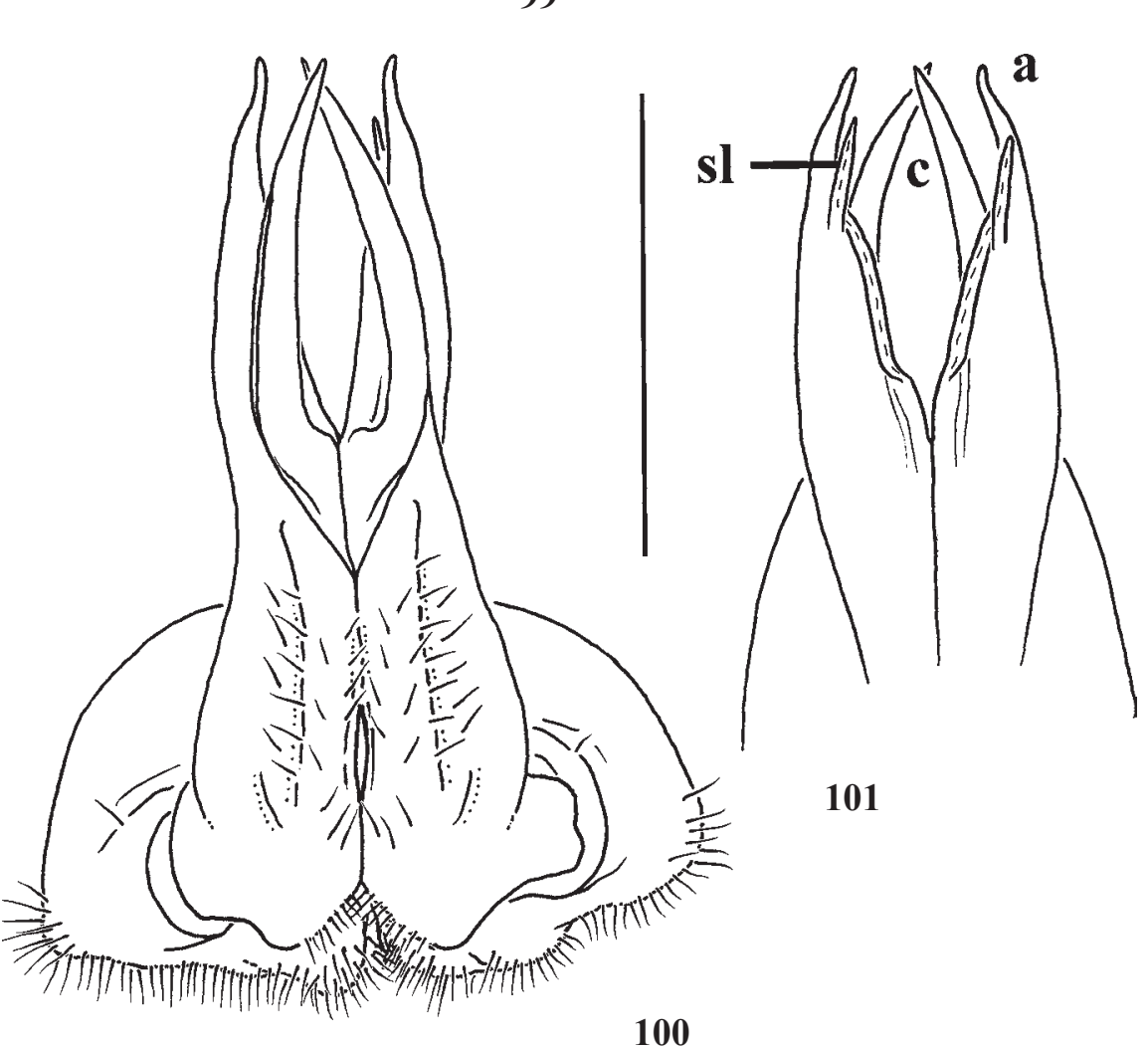

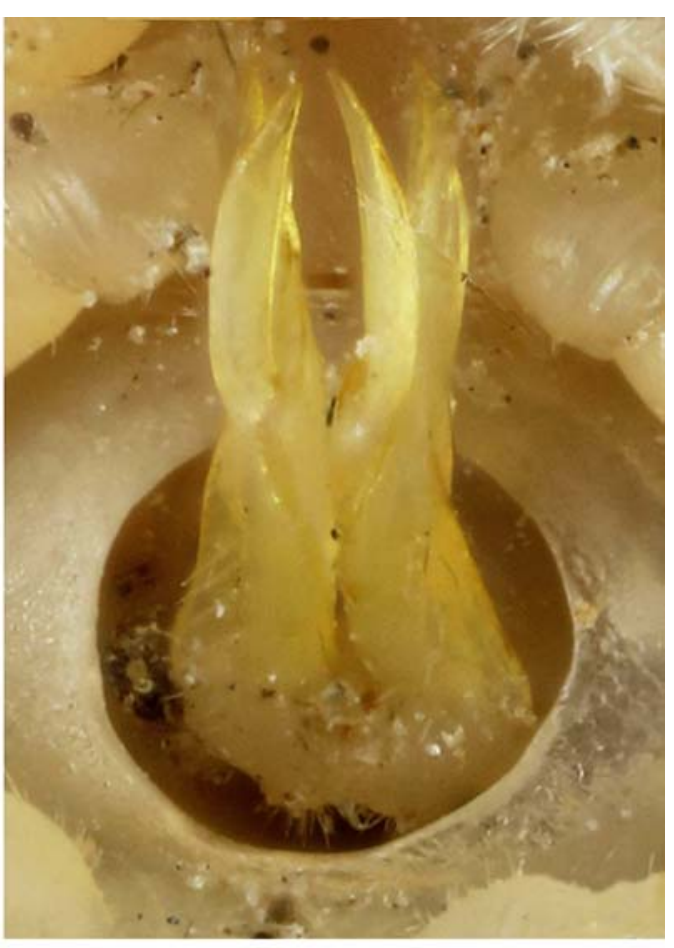

99

Figs 96-101. Anaulacodesmus lacustris Schubart, 1954, $0^{7}$ from National Park Puyehue. 96-98 - anterior, middle and posterior parts of body, ventral, dorsal and dorsal views, respectively; 99-101 - gonopodial block, posterior, posterior and anterior views, respectively. Pictures by K. Makarov, not taken to scale (96-99); scale bar: $0.5 \mathrm{~mm}(100-101)$. Designations in text.

Pис. 96-101. Anaulacodesmus lacustris Schubart, 1954, О7 из национального парка Puyehue. 87 - общий вид, сбоку; 88-91передняя, средняя и задняя части тела, соответственно сверху, снизу, сверху и сверху. Фотографии К. Макарова, без масштаба (9699); масштаб: 0,5 мм (100-101). Обозначения в тексте. 

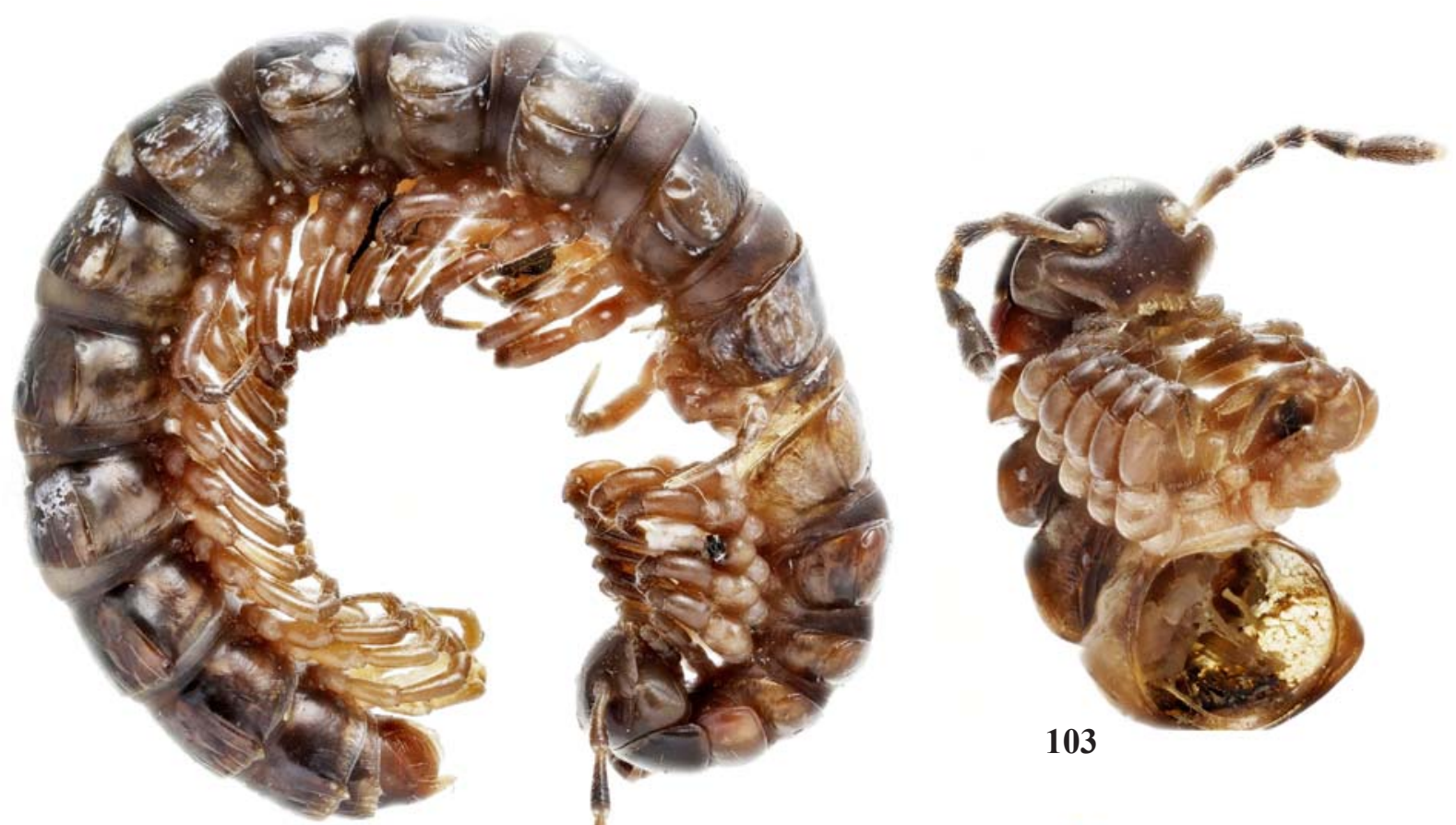

102

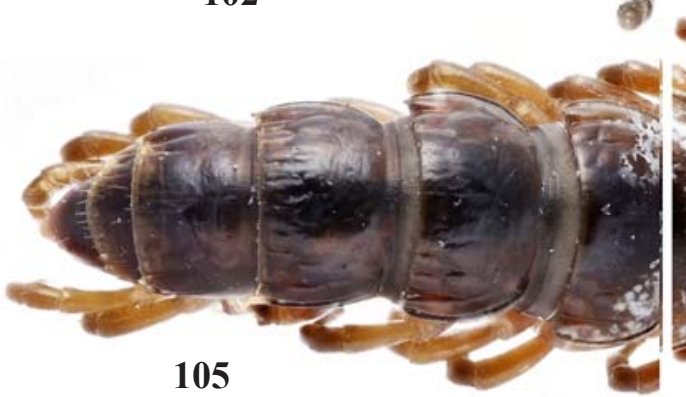

105

104

Figs 102-105. Anaulacodesmus levissimus Attems, 1898, O from National Park Nahuelbuta. 102 - habitus, lateral view; 103-105 anterior, middle and posterior parts of body, ventral, dorsal and dorsal views, respectively. Pictures by K. Makarov, not taken to scale.

Рис. 102-105. Anaulacodesmus levissimus Attems, 1898, О7 из национального парка Nahuelbuta. 102 - общий вид, сбоку; 103105 - передняя, средняя и задняя части тела, соответственно снизу, сверху и сверху. Фотографии К. Макарова, без масштаба.

broadly rounded, narrowly rimmed only dorsally, dentiform and slightly produced behind tergal margin only in segments 17 and 18 , set low, mostly lying at ca $1 / 3$ of midbody height. Metatergal areation strongly obliterated, increasingly well visible towards telson as three transverse rows of polygonal, setiferous fields, sublateral sulcus being especially evident. Tergal setae very short, mostly abraded. Pore formula normal $(5,7,9,10,13,15-19)$, ozopores dorsolateral, lying slightly in front of caudal corner. Body surface shining, below paraterga occasionally with a few arcuate striolae; texture microalveolate. Limbus microspiculate. Axial line and pleurosternal carinae wanting. Stricture dividing pro- and metazonae rather broad and shallow, very finely striolate dorsally and dorsolaterally. Epiproct long, subtruncate, subapical lateral papillae very small. Hypoproct linguiform, caudal edge broadly rounded, 1+1 setae borne on minute knobs well separated.

Sternites without modifications, sparsely setose; crossimpressions evident. Legs rather long, obviously incrassate $\left(\sigma^{7}\right)$, ca $1.2-1.3$ times as long as body height, prefemora 3-7 particularly strongly swollen laterally, increasingly poorly bulged thereafter; $\sigma^{\top}$ telopodites very densely setose ventrally, with abundant sphaerotrichomes.

Gonopods (Figs 124-127) with short, medially fused, basally densely setose coxites, the latter with curved, medially contiguous cannulae; telopodites contiguous medially, held subrectangular to coxae, suberect, each bearing a seminal groove on caudal face alone; prefemoral part sparsely setose, about as long as acropodite; the latter bifid, composed of a lateral, spiniform, inward curved solenomere (sl) and a very prominent, posterobasally bulged, caudal branch (c). No trace of an anterior branch.

ACKNOWLEDGEMENTS. I am most grateful to all collectors who entrusted me their material for treatment and who allowed most of it to be deposited in ZMUM. Their collecting trip was supported by RFBR grant 13-04-01839. Special thanks go to Kirill Makarov (Moscow, Russia), who so skillfully took the pictures, as well as to Dmitry Shcherbakov, Moscow, Russia, who kindly provided not only some material, but also a map showing the collecting localities. 

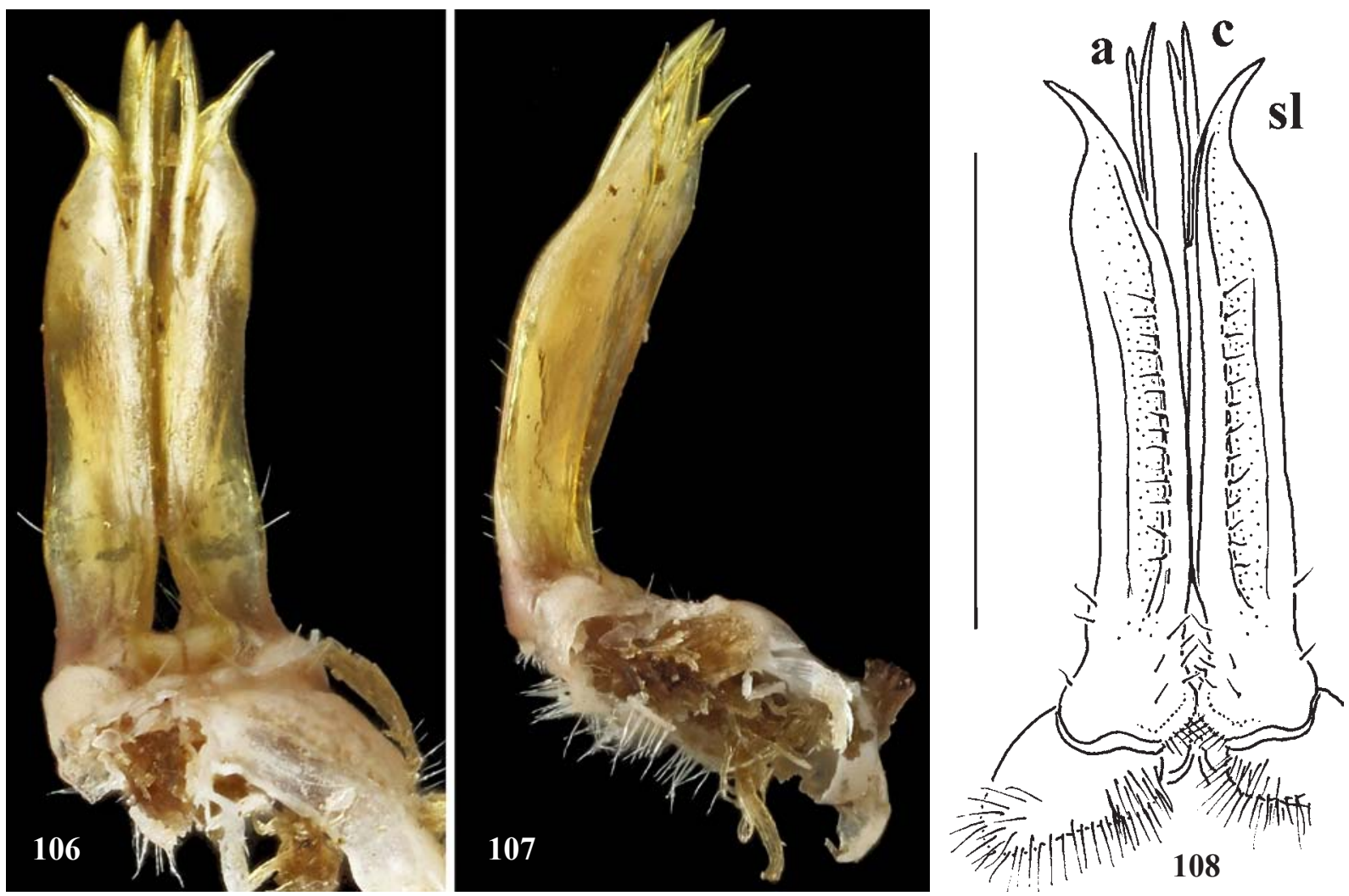

Figs 106-108. Gonopodial block of Anaulacodesmus levissimus Attems, 1898, O from National Park Nahuelbuta, posterior, lateral and anterior views, respectively. Pictures by K. Makarov, not taken to scale (106-107); scale bar: $1.0 \mathrm{~mm}$ (108). Designations in text.

Рис. 106-108. Гоноподиальный блок Anaulacodesmus levissimus Attems, 1898, О7 из национального парка Nahuelbuta, соответственно сзади, сбоку и спереди. Фотографии К. Макарова, без масштаба (106-107); масштаб: 1,0 мм (108). Обозначения в тексте.
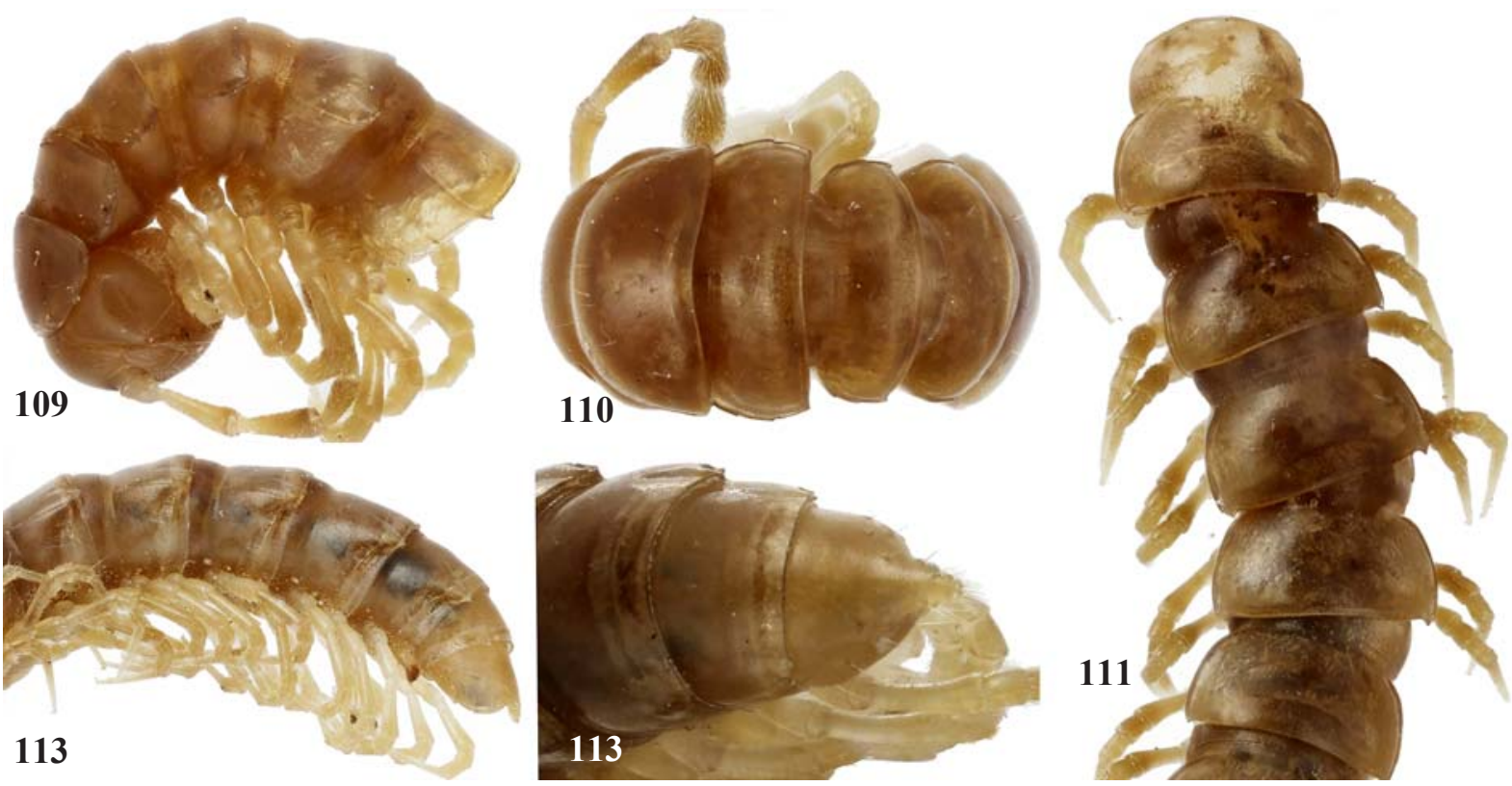

113

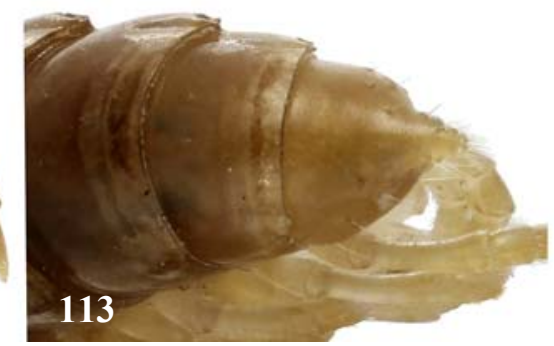

Figs 109-113. Anaulacodesmus levissimus Attems, 1898, o from National Park Chiloe, anterior, anterior, middle and posterior parts of body, lateral, dorsal, dorsal, lateral and dorsal views, respectively. Pictures by K. Makarov, not taken to scale.

Рис. 109-113. Anaulacodesmus levissimus Attems, 1898, О7 из национального парка Chiloe, передняя, передняя, средняя, задняя и задняя части тела, соответственно сбоку, сверху, сверху, сбоку и сверху. Фотографии К. Макарова, без масштаба. 

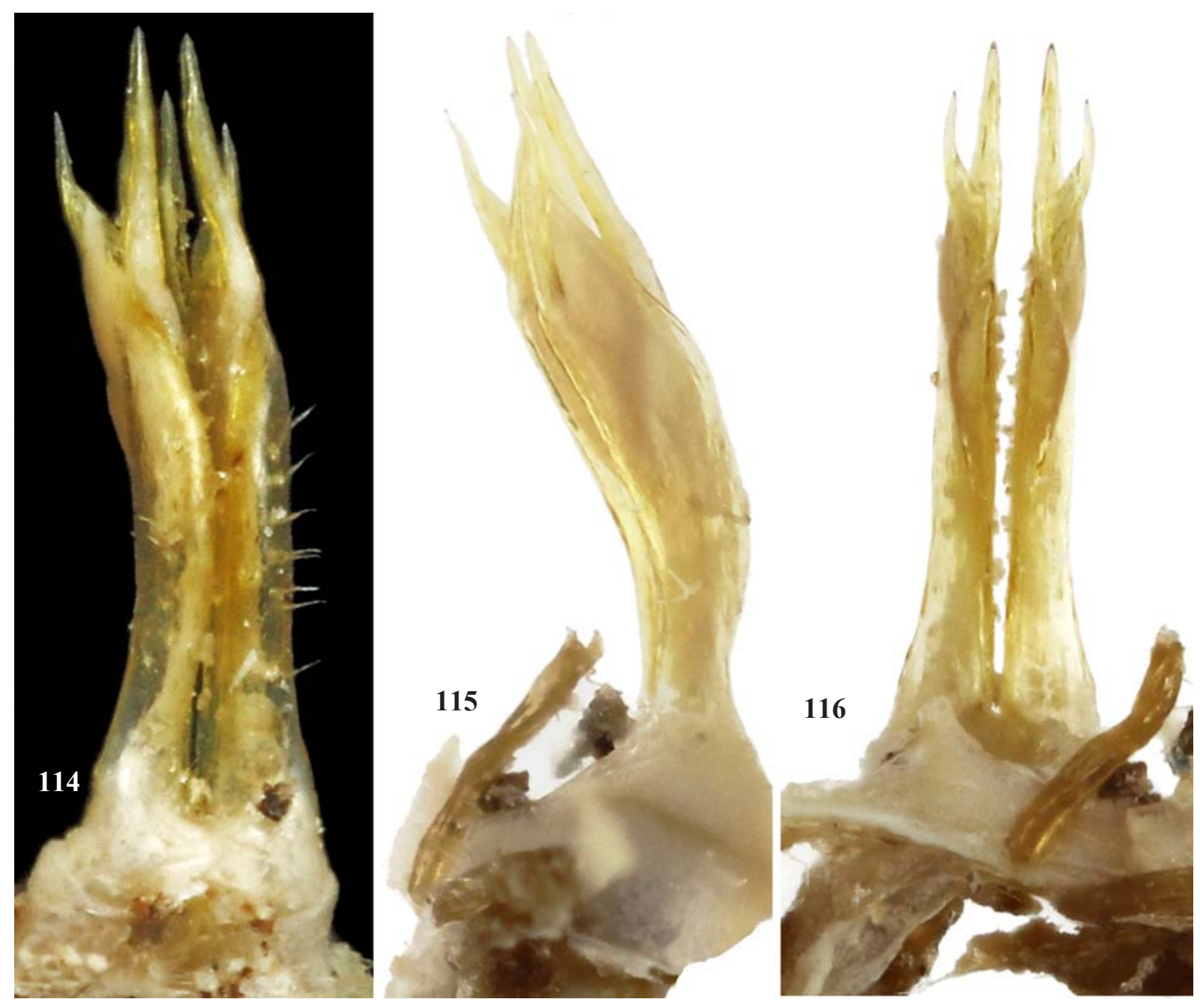

Рис. 114-116. Gonopodial block of Anaulacodesmus levissimus Attems, 1898, ơ from National Park Chiloe, subcaudal, lateral and anterior views, respectively. Pictures by K. Makarov, not taken to scale.

Рис. 114-116. Гоноподиальный блок Anaulacodesmus levissimus Attems, 1898, О7 из национального парка Chiloe, соответственно почти сзади, сбоку и спереди. Фотографии К. Макарова, без масштаба.

Figs 117-118. Gonopodial block of Anaulacodesmus levissimus Attems, 1898, $\sigma^{7}$ from National Park Chiloe, anterior and posterior views, respectively. Scale bar: $0.5 \mathrm{~mm}$. Designations in text.

Рис. 117-118. Гоноподиальный блок Anaulacodesmus levissimus Attems, 1898, О из национального парка Chiloe, соответственно спереди и сзади. Масштаб: 0,5 мм. Обозначения в тексте.

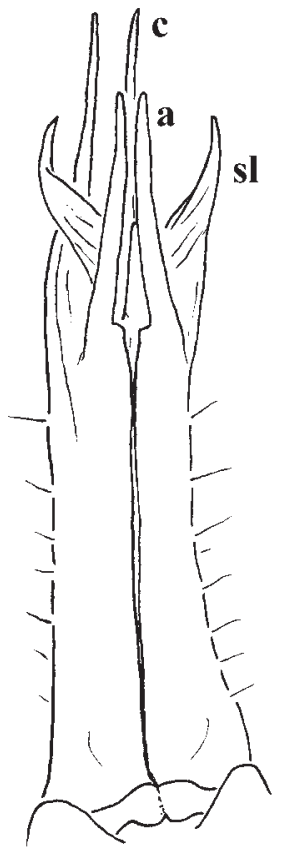

117

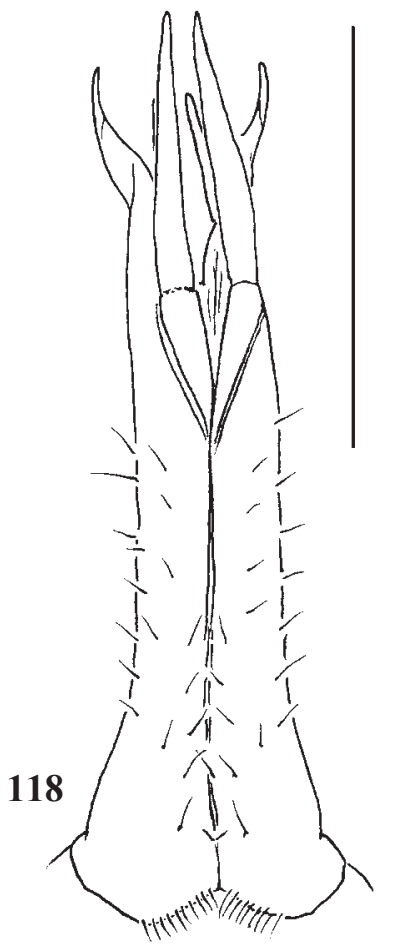




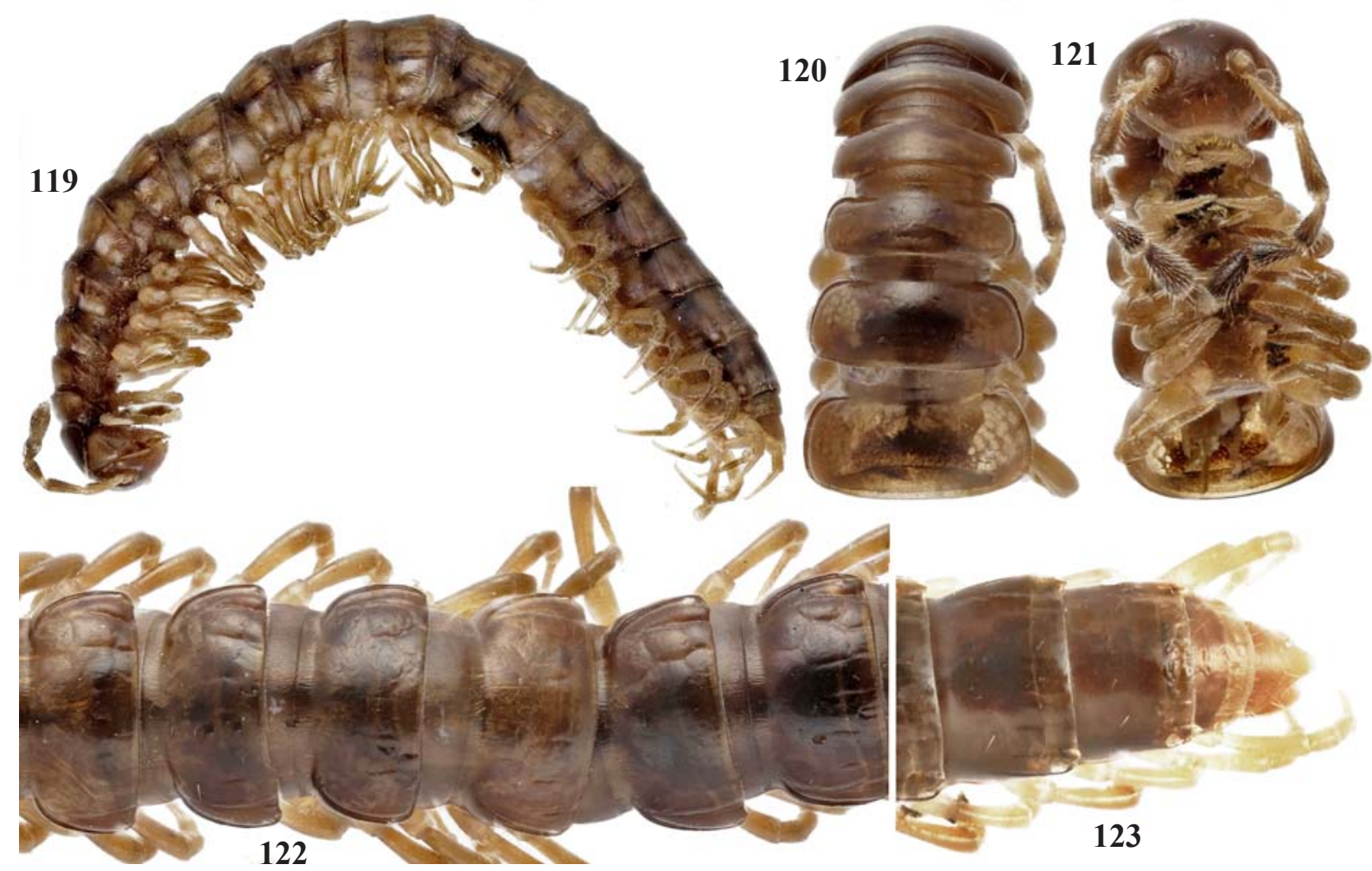

Figs 119-123. Anaulacodesmus bifidus sp.n., $0^{7}$ holotype. 119 - habitus, lateral view; 120-123 - anterior, anterior, middle and posterior parts of body, dorsal, ventral, dorsal and dorsal views, respectively. Pictures by K. Makarov, not taken to scale.

Рис. 119-123. Anaulacodesmus bifidus sp.n., голотип О’. 119 - общий вид, сбоку; 120-123 - передняя, передняя, средняя и задняя части тела, соответственно сверху, снизу, сверху и сверху. Фотографии К. Макарова, без масштаба.

124

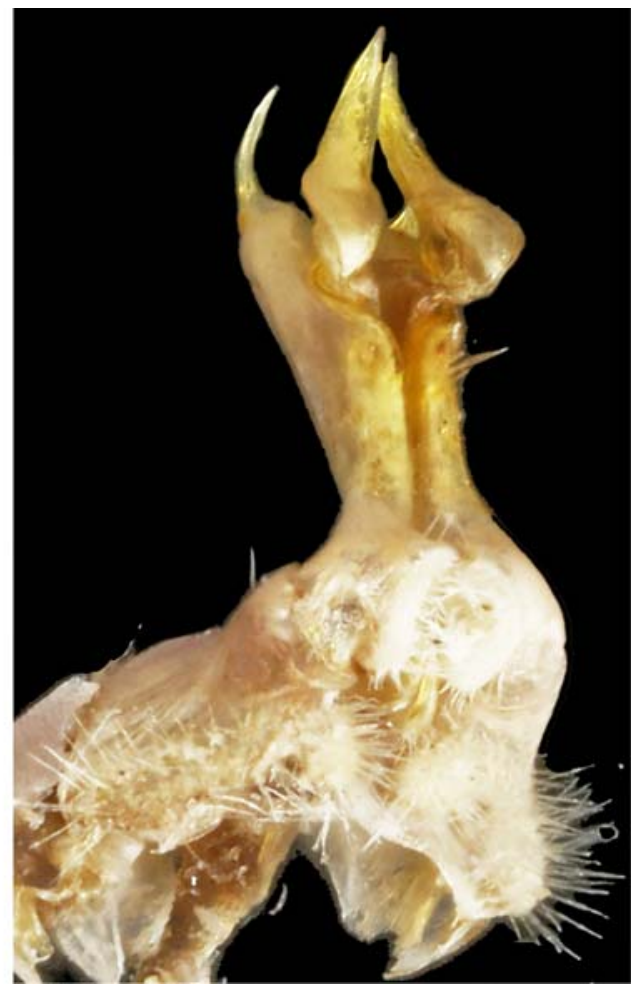

125

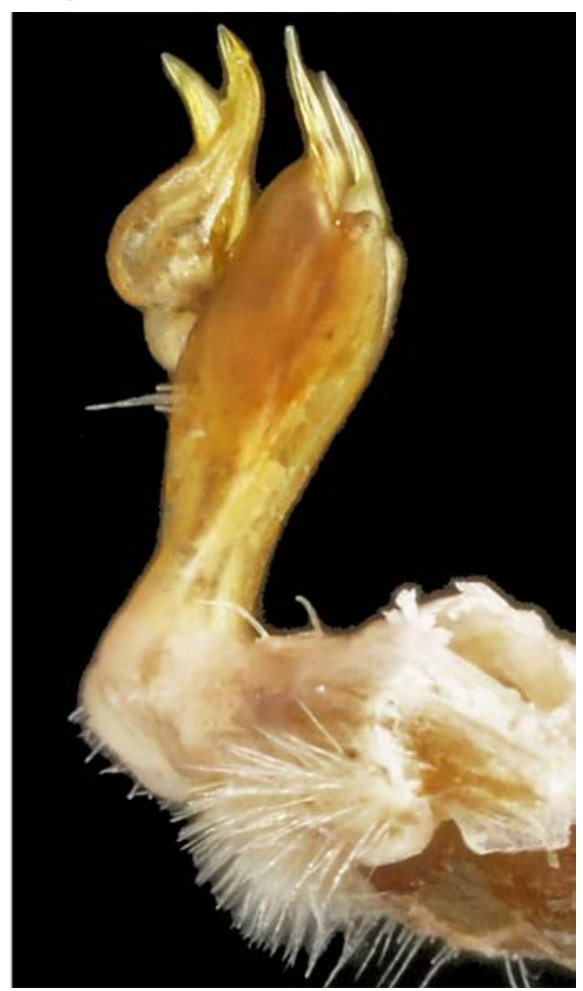

Figs 124-125. Gonopodial block of Anaulacodesmus bifidus sp.n., $0^{7}$ holotype, subcaudal and lateral views, respectively. Pictures by K. Makarov, not taken to scale.

Рис. 124-125. Гоноподиальный блок Anaulacodesmus bifidus sp.n., голотип О’, соответственно почти сзади и сбоку. Фотографии К. Макарова, без масштаба. 


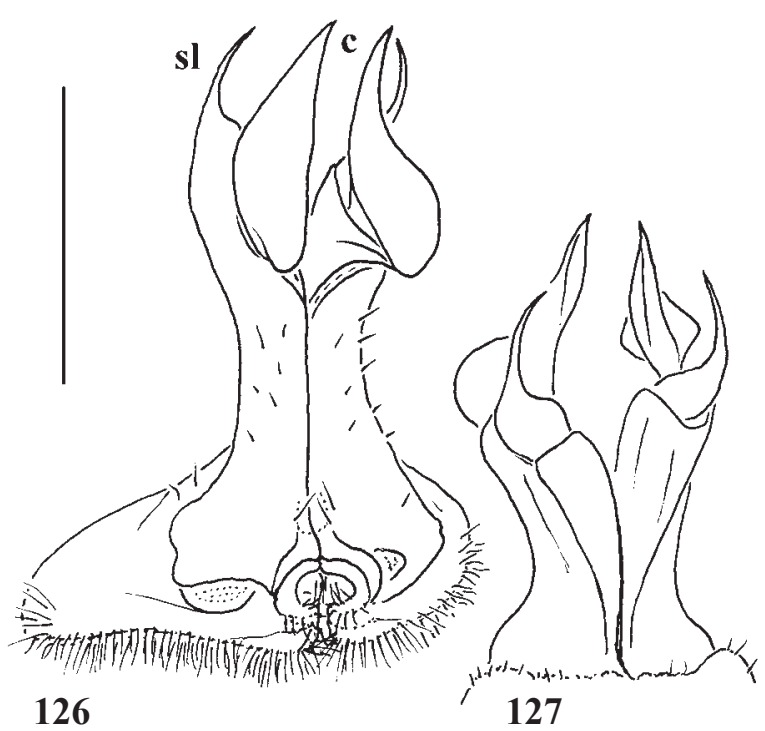

Figs 126-127. Gonopodial block of Anaulacodesmus bifidus sp.n., $\sigma^{7}$ holotype, posterior and anterior views, respectively. Scale bar: $0.5 \mathrm{~mm}$. Designations in text.

Рис. 126-127. Гоноподиальный блок Anaulacodesmus bifidus sp.n., голотип О7, соответственно сзади и спереди. Масштаб: 0,5 мм. Обозначения в тексте.

Elena Kudryavtseva and Kirill Mikhailov (both Moscow, Russia) helped to incorporate this material into the ZMUM collection.

The collectors are deeply indebted to Mario Elgueta (National Museum of Natural History, Santiago) and the CONAF staff of the relevant national parks for facilitating their field work in Chile.

\section{References}

Attems C. 1898. System der Polydesmiden. I. Theil // Denkschriften der Kaiserlichen Akademie der Wissenschaften zu Wien, Mathematisch-Naturwissenschaftliche Classe. Bd.67. S.221-482.

Attems C. 1903. Beiträge zur Myriopodenkunde // Zoologische Jahrbücher, Abteilung für Systematik, Geographie und Biologie der Thiere. Bd.12. S.63-154.

Attems C. 1914. Die indo-australischen Myriopoden // Archiv für Naturgeschichte. Bd.80A. H.4. S.1-398.

Attems C. 1940. Myriapoda 3. Polydesmoidea III. Fam. Polydesmidae, Vanhoeffeniidae, Cryptodesmidae, Oniscodesmidae, Sphaerotrichopidae, Peridontodesmidae, Rhachidesmidae, Macellolophidae, Pandirodesmidae // Das Tierreich. Lfg.70. S.1-577.

Chamberlin R.V. 1957. The Diplopoda of the Lund University and California Academy of Sciences expeditions. Reports of the Lund University Chile Expedition 1948-49, 30// Lunds Universitets Årsskrift. N.F. Avd.2. Bd.53. No.8. S.1-44.

Demange J.-M. 1963. Myriapodes p.101-108. // Cl. Delamare Deboutteville \& E. Rapoport (Eds). Biologie de l'Amérique australe. Etudes sur la faune du sol. T.2. Editions du CNRS: Paris.

Demange J.-M., Silva F.G. 1971a. Nouvelle espèce chilienne du genre Autostreptus Silvestri et description du matériel type de Iulus chilensis Gervais, 1847, type du genre (Myriapode, Diplopode, Spirostreptoidea, Spirostreptidae, Spirostreptinae) // Bulletin du Muséum national d'Histoire naturelle, Sér.2. T.42. No.4. P.708-715 (for 1970).

Demange J.-M., Silva F.G. 1971b. Abatodesmus velosoi nov. sp., nouvelle espèce chilienne de la famille des Sphaerotrichopidae

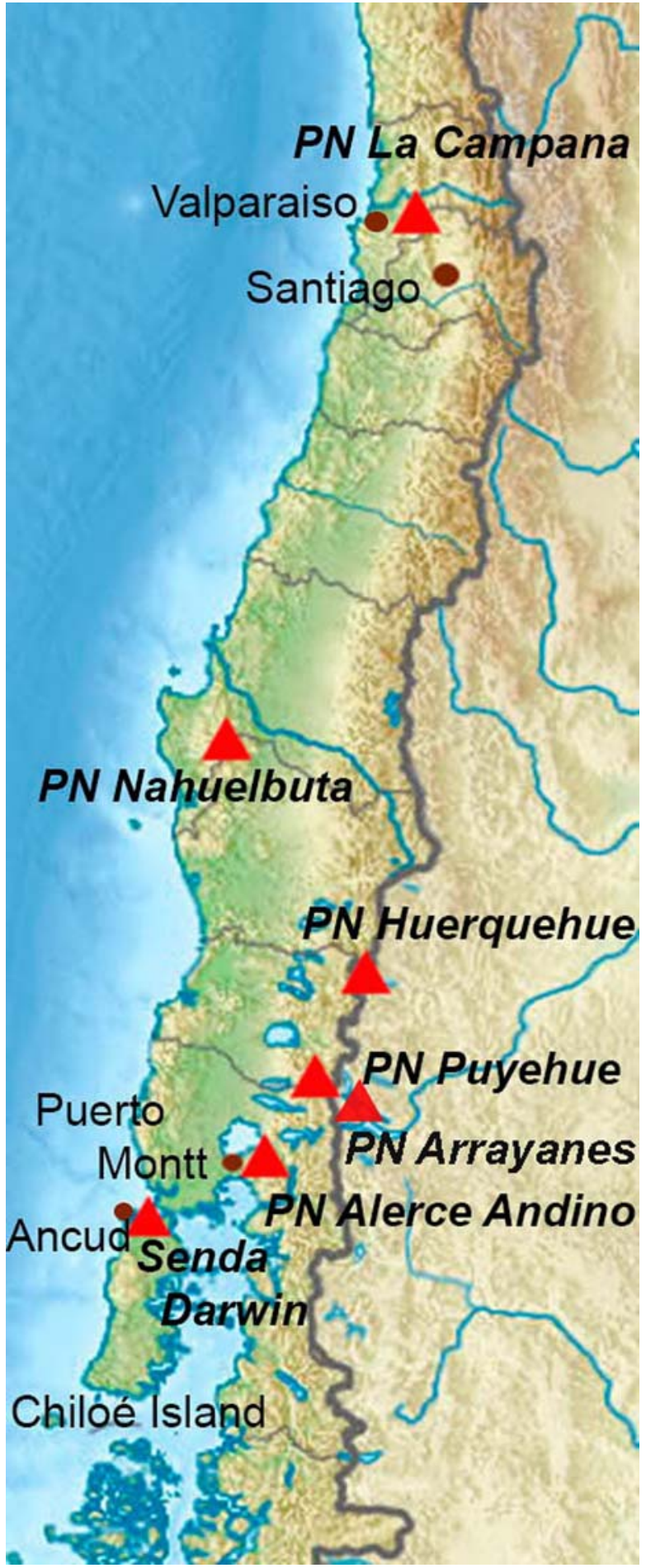

Map. The main collecting localities in Chile. Карта. Основные точки сборов в Чили.

(Myriapode, Diplopode : Polydesmoidea) // Bulletin du Muséum national d'Histoire naturelle. Sér.2. T.42. No.5. P.881-886 (for 1970).

Demange J.-M., Silva F.G. 1976a. Etudes de quelques genres chiliens de la famille des Sphaerotrichopidae (Myriapode, Diplopode, Polydesmoidea) // Bollettino del Laboratorio di Entomologia Agraria "Filippo Silvestri” di Portici. Vol.33. P.15-33. 
Demange J.-M., Silva F.G. 1976b. Contribution à la connaissance des espèces originaires du Chili décrites par F. Silvestri en 1902 // Bollettino del Laboratorio di Entomologia Agraria "Filippo Silvestri” di Portici. Vol.33. P.34-43.

González-Sponga M.Á. 2006. Miriápodos de Venezuela. Diez nuevas especies del género Rhinocricus (Spirobolida: Rhinocricidae) // Revista de Investigación. No.57. P.13-48 (for 2005).

Hoffman R.L. 1977. On the status of Siphonotus brasiliensis Brandt, and of the diplopod family Siphonotidae (Polyzoniida) (Diplopoda) // Deutsche Entomologische Zeitschrift. N.F. Bd.24. H.4/5. S. 425-431.

Hoffman R.L. 1979. A dalodesmid milliped from southeastern Brasil // Revue Suisse de Zoologie. T.86. Fasc.3. P.625-630.

Hoffman R.L. 1980. Classification of the Diplopoda // Muséum d'histoire naturelle. Genève. 237 p. (for 1979).

Hoffman R.L., Golovatch S.I. 2012. The millipede genus Argentocricus Verhoeff, 1941 (Diplopoda: Spirobolida: Rhinocricidae) // Arthropoda Selecta. Vol.21. No.3. P.211-215.

Korsós Z., Read H. 2012. Redescription of Zinagon chilensis (Silvestri, 1903) from Chile, with a species list of Iulomorphidae from the Southern Hemisphere (Diplopoda: Spirostreptida: Epinannolenidea) // Zootaxa. No.3493. P.39-48.

Marek P., Bond J.E., Sierwald P. 2003. Rhinocricidae systematics II. A species catalog of the Rhinocricidae (Fiplopoda: Spirobolida) with synonymies // Zootaxa. No.308, P.1-108.

Mauriès J.-P. 1998. Diplopoda p. 475-484. // J.J. Morrone \& S. Coscarón (Eds). Biodiversidad de Artrópodos Argentinos: Una Perspectiva Biotaxonómica. Ediciones SUR: La Plata, Argentina. $599 \mathrm{p}$

Mauriès J.-P., Silva F.G. 1971. Colobognathes du Chili I. Espèces nouvelles du genre Siphonotus Brandt (Diplopoda) // Bulletin du Muséum national d'Histoire naturelle, Sér.2. T.42. No.5. P.887-902 (for 1970).

Rodrigues P.E.S., Ott R., Rodrigues E.N.I. 2012. New species and new records of millipedes of the genus Rhinocricus Karsch,
1881 (Spirobolida: Rhinocricidae) from southern Brazil // Zootaxa. No.3172. P.55-64.

Schubart O. 1954. Diplópodos argentinos del Museo de la Ciudad Eva Perón. II. Familia «Sphaerotrichopidae» // Notas del Museo. Universidad Nacional de Eva Perón. T.17. Zoología. No.154. P.309-327.

Shear W.A. 1988. The chordeumatid millipeds of Chile (Diplopoda, Chordeumatida) // American Museum Novitates. No.2912. P.1-10.

Shear W.A. 2011. Class Diplopoda de Blainville in Gervais, 1844. // Z.-Q. Zhang (Ed.). Animal biodiversity: An outline of higherlevel classification and survey of taxonomic richness. Zootaxa. No.3148. P.159-164

Shelley R.M., Morrill E.D., Faber D.A. 2014. A julid milliped in Chilean Patagonia, and a compilation of ordinal representatives in South America and associated islands (Diplopoda: Julida) // Insecta Mundi. No.0366. P.1-8.

Silva F., Saiz F. 1978. Analyse phénologique de Myriapodes Diplopodes du Parc National "Fray Jorge", Chili // Abhandlungen und Verhandlungen des Naturwissenschaftlichen Vereins in Hamburg, N.F. No.21/22. S.167-175.

Silva F., Vivar C. 1976. Blaniulus guttulatus Bosc, en Valparaiso y region // Anales del Museo de Historia Natural de Valparaiso. T.9. P.173-175.

Silvestri F. 1903. Note diplopodologiche // Bollettino dei Musei de Zoologia ed Anatomia Comparata della R. Università di Torino. T.18. P.1-31.

Silvestri F. 1905a. Myriapoda. // J.W. Spengel J.W. Fauna Chilensis. Abhandlungen zur Kenntnis der Zoologie Chiles nach den Sammlungen von Dr. L. Plate. Bd.3 // Zoologische Jahrbücher. Suppl.-Bd.6. S.715-772.

Silvestri F. 1905b. Nuovi diplopodi del Chile // Revista chilena de Historia natural. Apo 9. No.5. P.225-236.

Weston P.H., Hill R.S. 2013. Southern (austral) ecosystems // S.A. Levin(Ed.). Encyclopedia of Biodiversity, second edition, Vol.6. P.612-619. Academic Press: Waltham, MA, USA. 